$9-2003$

\title{
The Architecture of Control: Shaker Dwelling Houses and the Reform Movement in Early- Nineteenth-Century America
}

Julie Nicoletta

University of Washington Tacoma, jn@uw.edu

Follow this and additional works at: https://digitalcommons.tacoma.uw.edu/ias_pub

Part of the Architecture Commons, History of Art, Architecture, and Archaeology Commons, and the Social History Commons

\section{Recommended Citation}

Nicoletta, Julie, "The Architecture of Control: Shaker Dwelling Houses and the Reform Movement in Early-Nineteenth-Century America" (2003). SIAS Faculty Publications. 22.

https://digitalcommons.tacoma.uw.edu/ias_pub/22 


\section{The Architecture of Control}

\section{Shaker Dwelling Houses and the Reform Movement in Early-Nineteenth-Century America}

JULIE NICOLETTA

University of Washington, Tacoma

$\mathrm{D}$ espite more than a decade of new research on Shaker history and architecture, the dominant public image of this religious sect, which flourished in early-nineteenth-century America, remains one of simplicity, perfection, social isolation, and religiosity. The Shakers themselves nurtured this view, and over the course of the 1800 s and 1900s, numerous articles, stories, and scholarly studies by outsiders have created various histories that obscure the reality of what the Shakers were and how they lived. The Shakers, or the United Society of Believers in Christ's Second Appearing, have become part of a myth of nineteenth-century rural America that asserts simplicity as the key value and isolation as the major desire in attempting to create a perfect society (Figure 1).

It is evident, however, that the group was neither simple nor isolated. The Shakers had a symbiotic relationship with the world that they could not deny despite their religious precepts that held that mainstream society was corrupt. They depended on converts to continue the growth of the sect. Their economic prosperity was possible only by trading with outside communities. In the late eighteenth and early nineteenth centuries, the Shakers' trade centered on local markets and farmers. Later on, the demand for Shaker goods also came from the mainstream American consumer, who, in an age of increasing industrialization and mass production, began to desire products reminiscent of a simpler American past. The Shakers in turn increased their consumption of manufactured goods as their economy changed from primarily agricultural to commercial.

These ties to the outside world are most evident in the Shakers' own architectural developments in the first half of the 1800 s. Their desire to create villages as orderly communities with buildings that would control behavior and shape men, women, and children into proper members of the Shaker community paralleled the rise of institutions of reform and confinement in the United States of the same period. As did their counterparts in mainstream culture, the Shakers felt that humans could and should be transformed into respectable members of society. They believed they could accomplish this goal by exerting control over humans through well-designed architecture using the concept of surveillance to enforce behavior. The Shakers, as did worldly reformers, enthusiastically practiced their own reforms and met with success in the first half of the nineteenth century, only to see failure in the loss of members beginning in the late 1840s.

In this article, I analyze the architecture of control and surveillance by focusing on Shaker dwelling houses and putting them into the larger context of reform in the era of the early republic. ${ }^{1}$ Specifically, I compare the development of Shaker dwelling houses with the Quaker-led reform of prisons and insane asylums during the period of religious revivals known as the Second Great Awakening to demonstrate how and why the Shakers incorporated ideas from the outside world and applied them to their own buildings. I 




JOURNAL of the SOCIETY of ARCHITECTURAL HISTORIANS

\section{JOURNA}

$\operatorname{tin} 3 y^{2}$

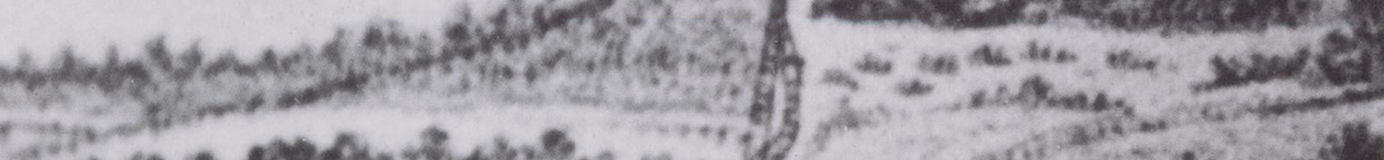

C:47:

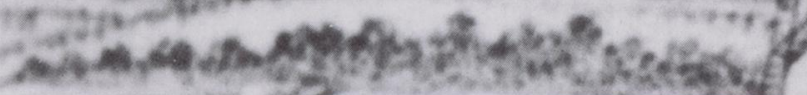

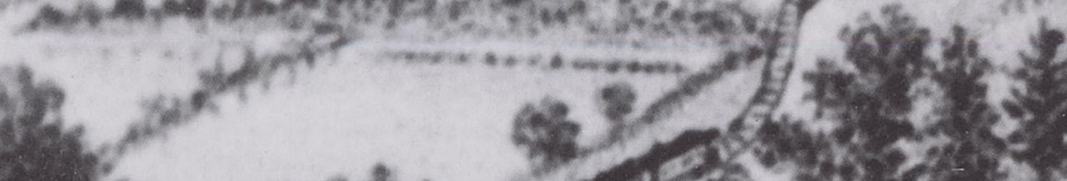



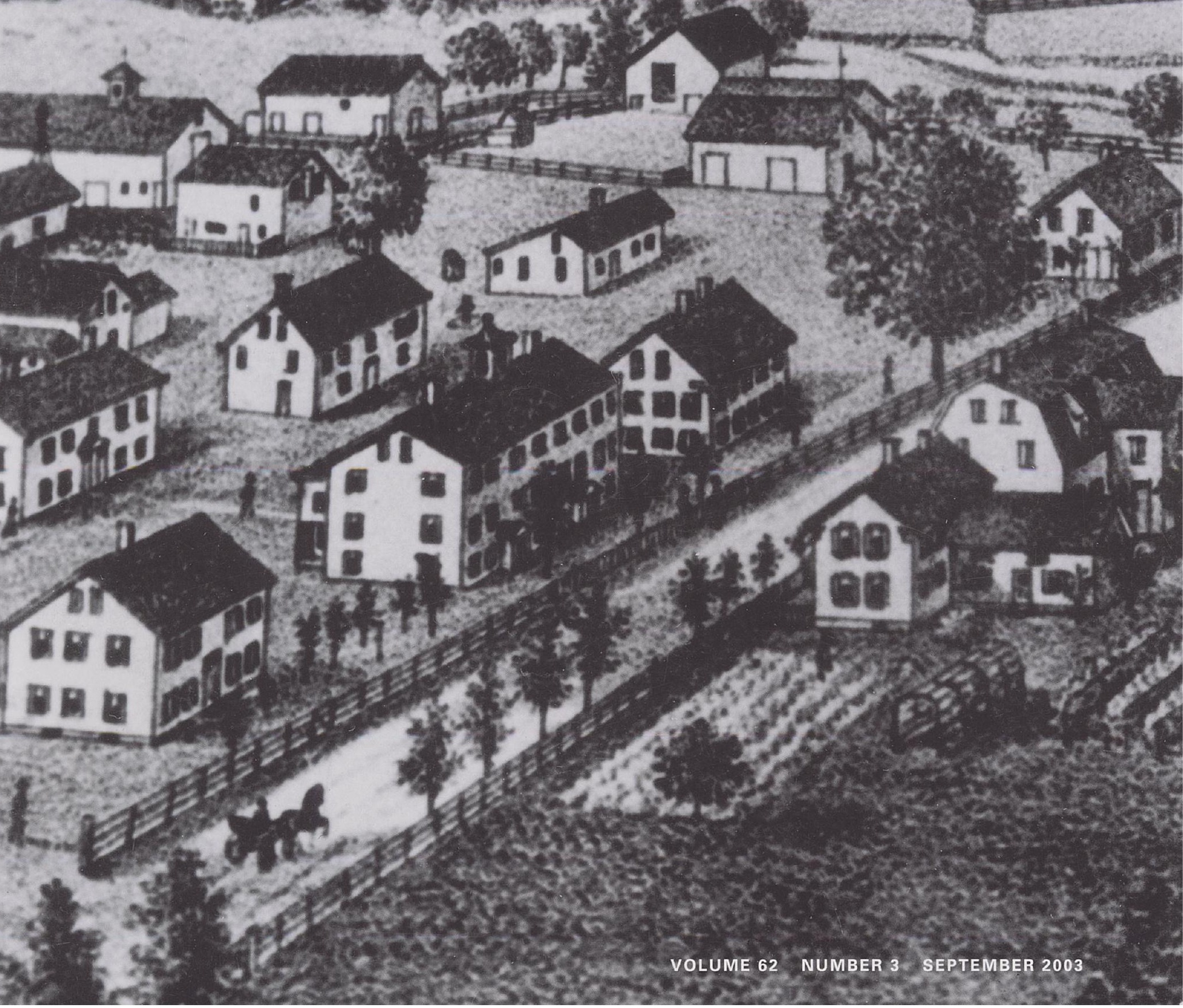

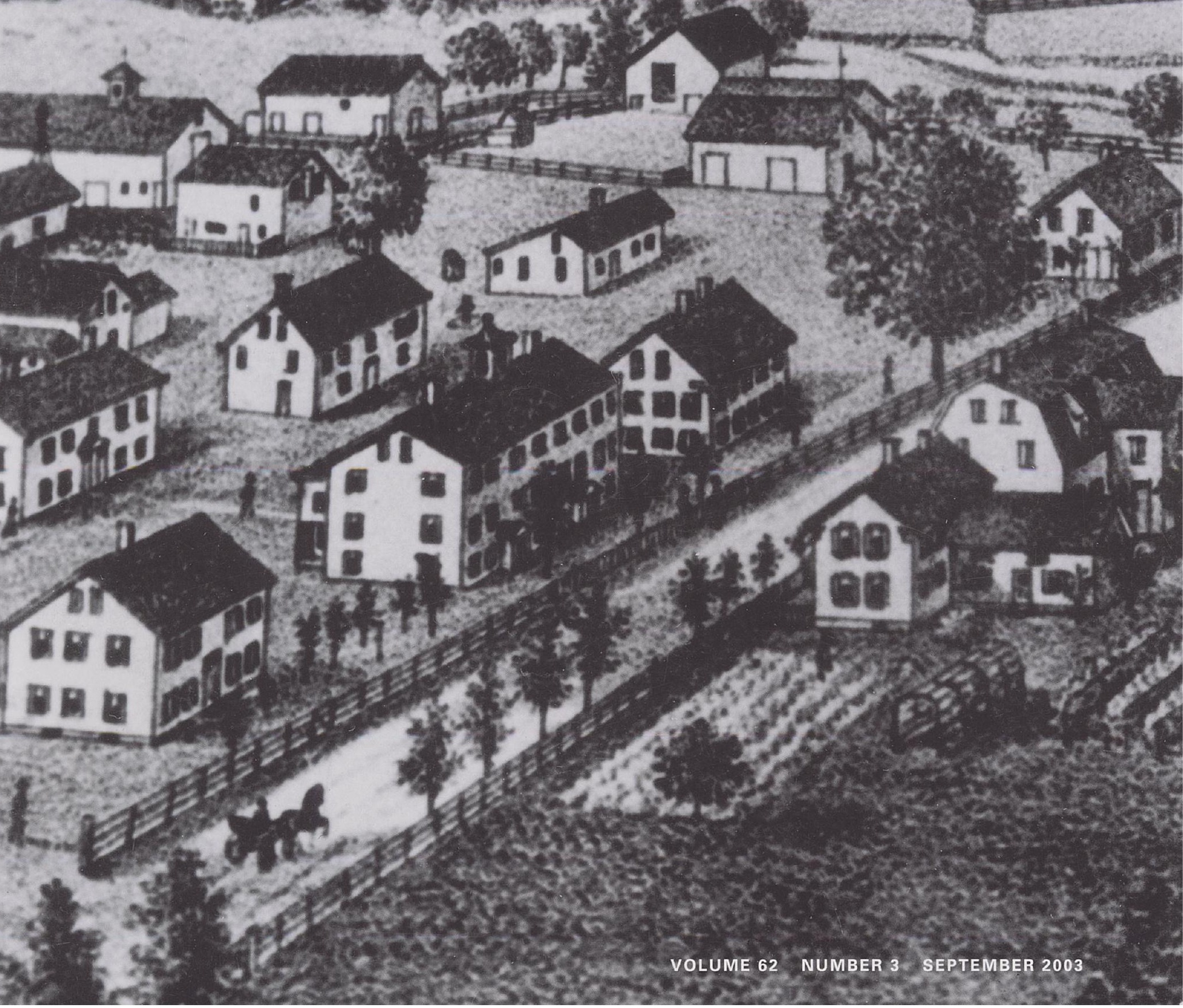

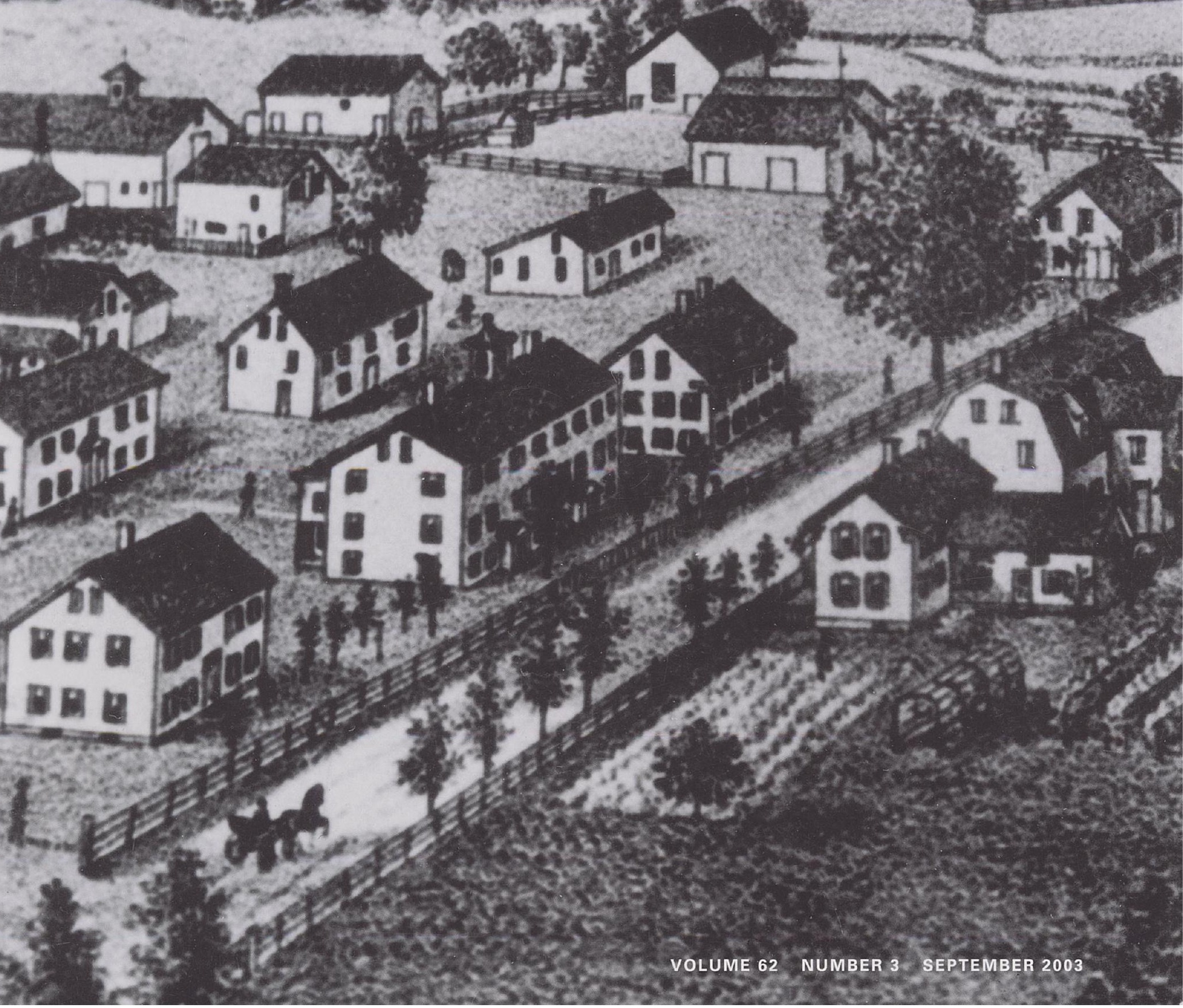

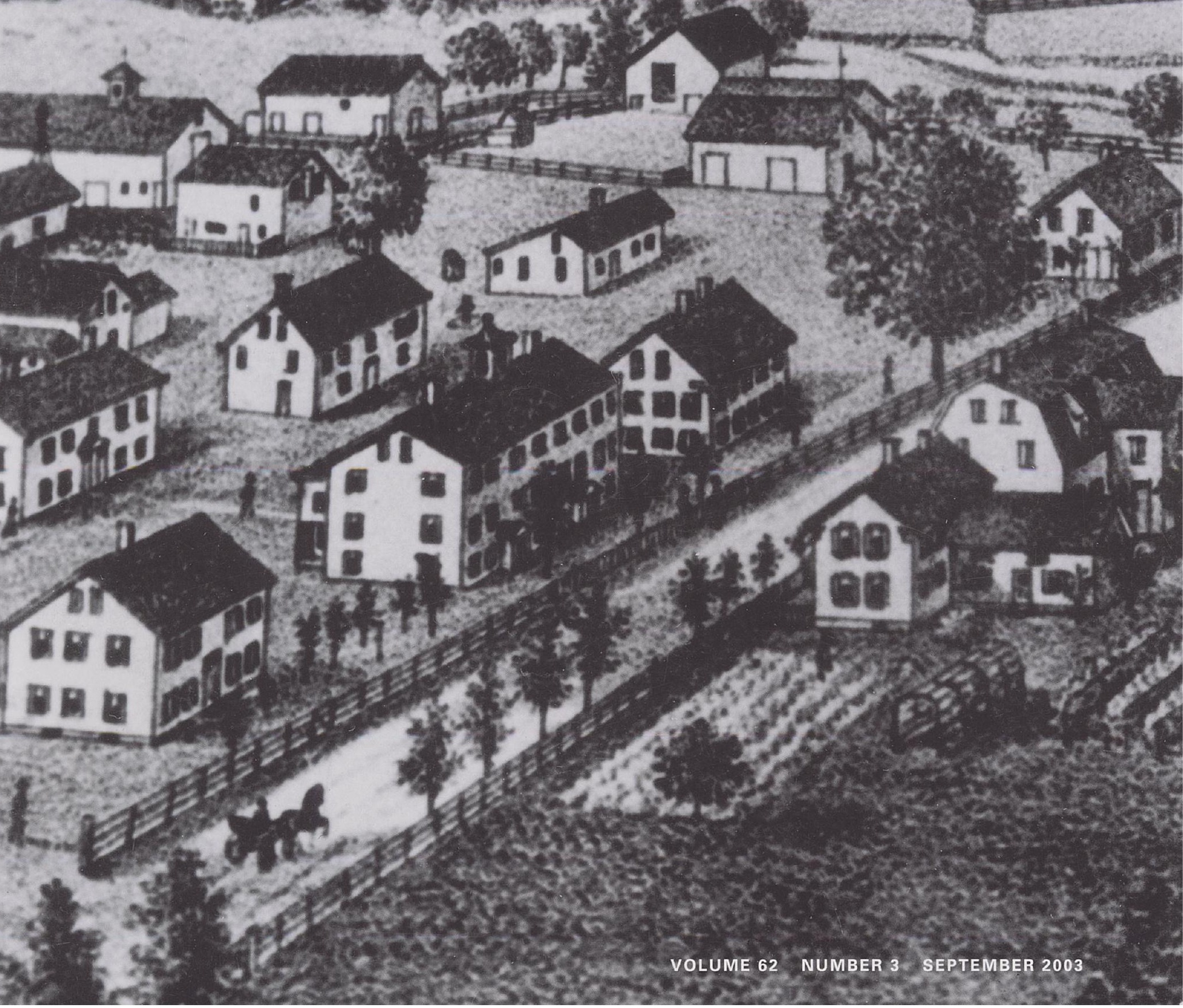

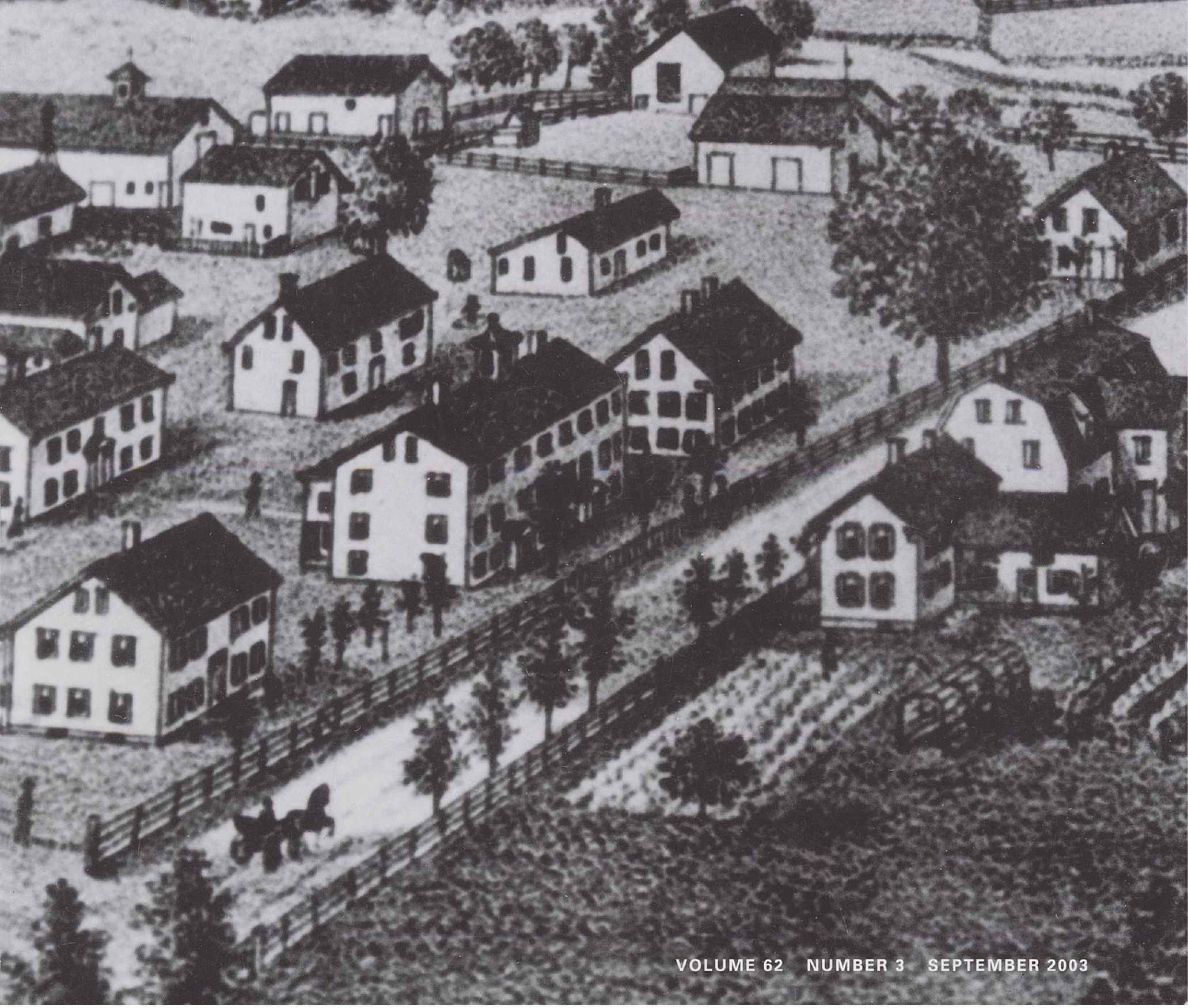

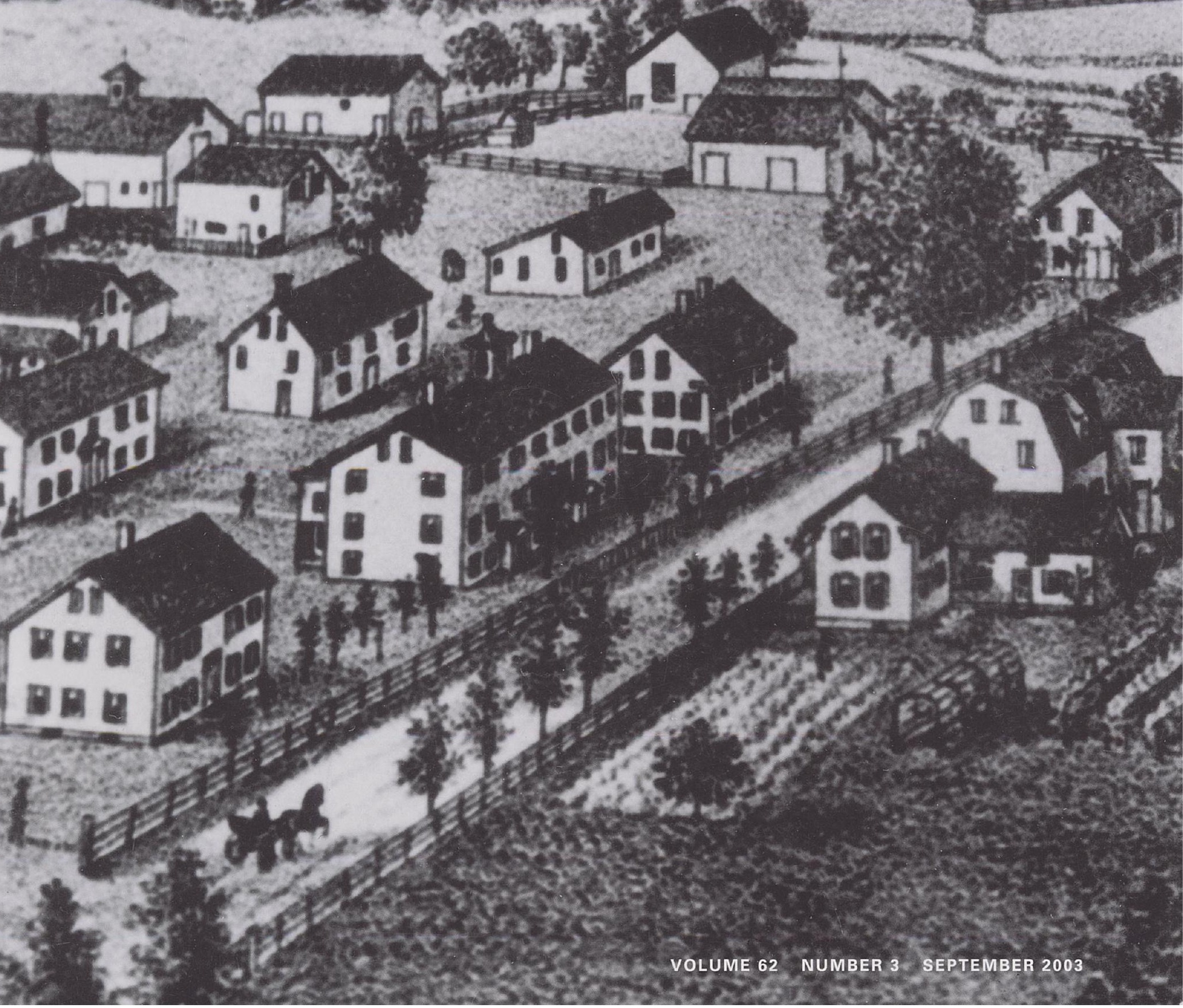






Figure 1 Shaker village,

Alfred, Maine, ca. 1880.

Lithograph from W. W.

Clayton, History of York

County, Maine

(Philadelphia, 1880),

unpag.

also discuss the Shakers' treatment of their mentally ill members. The dwelling houses, as the focus of Shaker daily life and worship, tell us much about how the Shakers used their buildings and the space created by them to try to construct a utopia in which all members lived in unison and in which individuals subordinated themselves to the good of the whole. ${ }^{2}$

Recent scholarship has shown that the Shakers not only attempted to strike a balance between their world and mainstream society, but that they also clearly borrowed from prevailing designs and adapted them to suit their needs. Robert P. Emlen's Shaker Village Views demonstrates that though Shaker villages were distinctive, they evolved from mainstream American towns. ${ }^{3}$ Although June Sprigg and Paul Rocheleau's Shaker Built: The Form and Function of Shaker Architecture presents a more traditional view of the Shakers as simple builders, it offers detailed descriptions and beautiful photographs of many Shaker structures. ${ }^{4}$ My book, The Architecture of the Shakers, notes that late-eighteenth-century Shaker architecture in the Northeast drew on AngloDutch examples in eastern New York, where the earliest and most influential Shaker villages were founded. By the early 1800s, Shakers were modeling meeting houses, dwelling houses, and workshops on the Federal style. ${ }^{5}$ The furniture historian John T. Kirk, in The Shaker World: Art, Life, Belief, makes a convincing case that Shaker decorative arts were "very much like vernacular work made around Shaker communities" that had adopted a stripped-down version of the Neoclassical style and that the Shakers reduced "this aesthetic to a unified simplicity." Scott T. Swank elaborates on these ideas in Shaker Life, Art, and Architecture: Hands to Work, Hearts to God, in which he focuses on the Canterbury, New Hampshire, community to examine design in the context of the Shakers' daily lives, beliefs, and behavior pat- terns. ${ }^{7}$ A significant contribution of all these studies is that they look at Shaker material culture as evolving rather than fixed in a specific time period, as earlier Shaker experts and collectors had. The recent research is instrumental in examining Shaker architecture in the context of reform.

The reform impulse of the Jacksonian age has captured the attention of numerous authors. As the social historian David J. Rothman has noted, "a rich and imaginative literature traces the history of American and European prisons, mental hospitals, reformatories, orphanages, and almshouses, with books and articles numbering well into the hundreds." Scholars have examined how the desire for order in an age of rapid industrialization and change manifested itself in the creation of institutions of confinement that used discipline and surveillance to shape deviants into proper members of society. Rothman writes that the "very openness [of Jacksonian America] was producing disorder and disarray." $\mathrm{He}$ states that one aspect of disorder was a perceived rise in crime, and Americans devised new types of institutions to combat it. Other researchers have looked at the role of republican citizenship as a means to create civic virtue shared by all the nation's inhabitants, thereby ensuring social order. Dell Upton has argued that this notion was exercised in the development of Lancasterian schools, which were intended to transform children into virtuous Americans using architecture, discipline, and economies of scale in education. ${ }^{10}$ Nevertheless, little analysis has been conducted on how utopian communities contributed to this movement. The location of prisons and asylums beyond the boundaries of the city, seen as a source of corruption, and the creation of isolated, inward-looking environments at these institutions suggest that a utopian impulse lay behind some of the reform efforts of the period. A study of Shaker dwelling houses demonstrates that the 
communal sect believed it could serve as a model for changing society as well. It is not surprising, then, that domestic and foreign travelers alike considered Shaker villages important destinations on a par with the new prisons and asylums being constructed in America. Illustrious visitors including Gustave de Beaumont, Alexis de Tocqueville, and Charles Dickens added Shaker communities to their list of American places to see.

The rise of evangelicalism during the Second Great Awakening provides another explanation for the intense interest in reform institutions in the first half of the nineteenth century. Out of the revivals came a desire to improve society through voluntary associations that promoted a range of goals including missionary work, publication and education societies, and moral reform. ${ }^{11}$ By looking at the larger context of reform, initially led by the Quakers, we can see that the Shakers were not out of place, but were one of many groups trying to create a better model for society.

\section{A Brief History of the Shakers}

By the turn of the nineteenth century, the Shakers had already been in America for more than a quarter of a century. Founder Ann Lee and ten followers, seven men and three women, had arrived in New York City from Manchester, England, in 1774. Influenced by a radical sect of Quakers in England, Lee had created a new religion drawing from Quakerism as well as from her own personal beliefs. Under Lee, Shakerism encouraged individual religious expression, argued that the Christ spirit dwelled within each person, emphasized the spoken word, anticipated the imminent millennium, preached equality of the sexes, and professed celibacy as a way for its members to be more like Christ. The historian Stephen J. Stein asserts that the Shakers' decision to leave Manchester resulted from their lack of success in spreading the faith in England. The American colonies, the Shakers believed, held more potential for attracting converts. ${ }^{12}$ After their arrival in New York, the small group split up for a few years in order to make money and to adjust to their new environment. In 1779, a relatively wealthy member of the group, John Partington, purchased land in Niskeyuna, later called Watervliet, just west of Albany. There the group reassembled and set to work proclaiming their faith and seeking converts. From 1781 to 1783 , Lee and her two closest followers, her brother William Lee and James Whittaker, conducted a missionary tour of New England that resulted in the conversion of hundreds of Shakers. The trip, though successful, took its toll.

On 8 September 1784, Ann Lee died unexpectedly, only two months after her brother's death. The loss of the founder and leader of the sect brought on a crisis among the Believers. Many Shakers left the group, disillusioned that Mother Ann would not be present for the coming millennium. The strength of her successors kept the movement going, however, even though Shakerism changed drastically. Both Whittaker and Joseph Meacham, a converted Baptist minister from New Lebanon, New York, began implementing structures that organized worship and community.

Two significant changes occurred under Whittaker that initiated the move toward a communal society. First, Whittaker ordered that all members should give their personal possessions to the church. He intended this command to help initiate the conversion of the entire world to Shakerism. ${ }^{13}$ Second, Whittaker set about developing the settlement at New Lebanon, about thirty miles southeast of Albany, into a community by ordering the first Shaker meetinghouse to be built, in the fall of 1785 , under the supervision of the Shaker builder Moses Johnson. The symmetrical, gambrel-roofed structure was the first one the Shakers used specifically for worship. Under Lee, there had been no standard place of worship; the Shakers had met wherever and whenever the spirit moved them-in the woods, in a friendly neighbor's house, or during proselytizing tours. The meetinghouse helped formalize worship by functioning as the community's central gathering place. The success of the new meetinghouse encouraged the construction of similar buildings at other Shaker villages in the Northeast; between 1786 and 1794, Johnson erected nine additional meetinghouses.

After Whittaker's death in July 1787, Meacham, American-born and a Shaker since 1780, emerged as the next leader. Upon his conversion to Shakerism, most of his Baptist congregation followed him. Meacham's talent for creating hierarchies to organize religious and communal life made a lasting impact on the society. He was vital in preserving the Shaker movement and strengthening it so that it could continue into the nineteenth century. ${ }^{14}$ Meacham advocated the idea of communal societies, eventually establishing communities in all the Shaker villages. Indeed, the social structures he formulated still exist to some extent today in Sabbathday Lake, Maine, the only surviving Shaker community. His innovations in New Lebanon set the standard by which all other Shaker communities were measured.

One of Meacham's first steps as leader was to issue a call to members to gather into "gospel order" or "church relation," an official communal society with shared property and shared duties, in New Lebanon. The 105 men and women left their homes and settled on farms donated to the sect by families that had converted to Shakerism..$^{15}$ The 
effort to draw the Shakers together in New Lebanon into a formally organized group marked a drastic departure from the loosely connected association of Believers under Lee and Whittaker. Under Meacham, the society turned away from its earlier roots in ecstatic worship. ${ }^{16}$ By 1794 , eleven villages in New York and New England, including New Lebanon, were established in gospel order.

In another innovative move, Meacham selected Lucy Wright as his female counterpart. Mother Lucy, as she came to be known, had joined the Shakers in about 1780 and had lived in Niskeyuna with Mother Ann. Like Meacham, she was well respected and regarded by the Shakers as a capable leader. Together they implemented the structure and rules necessary to organize the society.

The desire for order became overwhelmingly important and pervaded the numerous decisions made by the Shaker leaders. In 1792, Meacham and Wright divided the New Lebanon community into three families-First, Second, and Third. They organized the families by age and by the different levels of commitment to Shakerism that the members professed. They also emphasized that families were not to interact. The most committed were not to be tainted by less fervent members. The First Family, or First Order, represented those who had made the greatest commitment to the Shaker faith. Members officially exhibited their commitment by signing the covenant, a practice that was established in December $1795 .{ }^{17}$ The covenant served as a legal document in which the signer relinquished all private property to the community. It was devised to protect the Shaker church from lawsuits brought by apostates for back wages and property given to the society. The Second Order was made up of the elderly; to the Third Order belonged the youth, or novices. Each family had a set of elders and eldresses, trustees, and deacons and deaconesses. The elders served as the spiritual leaders of the family; the trustees handled the affairs of the world; and the deacons were the temporal leaders. Trustees and deacons lived separately from the main body of members so they could perform their duties without bringing into the community worldly influences that could corrupt the rest of the brothers and sisters. Whereas the Shakers did not always follow these strict divisions in practice, the existence of such policies attests to the leaders' desire to shield members from the world and exert influence over them.

By dividing the members into three families each with their own leaders, Meacham and Wright could better disseminate and enforce the new rules they were developing. The creation of families in New Lebanon and all the other Shaker villages also served to replace the natural families of converts. Shaker leaders instructed members to consider the elders and eldresses as their fathers and mothers, their compatriots as brothers and sisters. They would live together as a spiritual and temporal family more potent than those of the world. In New Lebanon, the original three families would eventually evolve into eight, based on their geographic location relative to the meetinghouse and the First Family-also known as the Church Family in the East-and on the level of commitment of family members. A similar arrangement occurred at Shaker communities in the West (Kentucky, Ohio, and Indiana), where the Church, or Center, Family served as the nucleus around which other families and the village developed.

Another important change was the creation of a ministry and bishoprics. The ministry consisted of a select group of two elders and two eldresses who oversaw a bishopric made up of three or four adjacent communities. ${ }^{18}$ At the top of the hierarchy stood New Lebanon, which became the lead ministry for all of Shakerdom. The rest of the officers, the other ministry elders, family elders, trustees, and deacons reported back to the New Lebanon ministry.

Meacham died in 1796. Wright, as sole leader, oversaw the expansion of Shakerism into Kentucky, Ohio, and Indiana. By 1826, the Shakers had established nineteen permanent communities. In 1821, after Wright's death, a small number of brethren in New Lebanon set down and circulated the Millennial Laws to all Shaker communities. The laws pertained to all areas of Shaker life, including the construction, appearance, and use of dwellings; for example, "Odd or fanciful styles of architecture, may not be used among Believers, neither should any deviate widely from the common styles of building among Believers, without the union of the Ministry." Another rule regarding interiors reads: "Varnish, if used in dwelling houses, may be applied only to the movables therein, as the following. . . Tables, stands, bureaus, cases of drawers, ... etc. Bannisters or hand rails in dwelling houses may be varnished." "Like the changes in worship, the rules were meant to standardize the appearance of dwellings and the villages themselves. Architectural orthodoxy could better reinforce religious and social rules of behavior. As recent scholarship has revealed, however, the Millennial Laws were not necessarily followed to the letter. Stein has pointed out numerous instances when Shakers in other communities, particularly in the West, resisted the power the New Lebanon ministry tried to exert from afar. ${ }^{20}$ Historians of Shaker material culture have also noted that the Millennial Laws cannot be considered an absolute measure of Shaker control; nevertheless, they have pointed out that the consistencies of style in architecture and in furniture design indicate that the New Lebanon ministry did, indeed, exert influence throughout the Shaker world. ${ }^{21}$ 


\section{The Second Great Awakening}

The Second Great Awakening gave rise to a new wave of reform and utopian movements that proved to be more widespread and longer lasting than any trend seen before in America. Beginning in New England in the 1790s, the Second Great Awakening embodied a series of religious revivals that spread from the East Coast to the Ohio River valley. It built on the legacy of the Great Awakening of the 1730 s and 1740s, which brought "Enlightenment ideas of optimism and individual liberty into orthodox Calvinist theology and social theory."22 The Great Awakening also emphasized the experience of conversion and the free will of humans in that process; conversion became one of the hallmarks of this wave of revivals.

The Second Great Awakening promised individuals a direct relationship with God, unburdened by church hierarchy. Evangelical converts gained a greater sense of their own responsibility in overcoming sinful behavior. With this new realization came a desire to join in a collective experience, often by participating in a mission or reform movement. ${ }^{23}$ Such freedom gave renewed impetus to the development of dissenting religious groups, such as the Baptists and the Methodists, and to fringe religions including the Shakers, for whom evangelicalism was an important component. Evangelical fervor emphasized a reliance on Scripture, religious conversion, and missionary work, paving the way for less traditional sects to gain converts. The Shakers took advantage of the revivals, primarily finding new converts in upstate New York, one of the regions most heavily swept by the awakening, and in Kentucky and Ohio during and shortly after the Cane Ridge Revivals of 1801.

The Second Great Awakening lasted into the 1840s. It seems to have been a response to several transformations occurring in America after the Revolution. According to the historian of religion Edwin Scott Gaustad, the break between church and state in the United States, the French Revolution's attack on the churches and clergy, the "hostile rationalism" of men such as Thomas Paine who ridiculed biblical revelation, and the influx of immigrants into the country all provoked fears that society was becoming more chaotic. ${ }^{24}$ The Second Great Awakening served as both a stand against liberalism and an effort to create an orderly American society. Freed from the constriction of state governance, religious groups were able to form voluntary associations to address a variety of social problems. The period of revivals also helped democratize religious culture, providing options and opportunities among religious ideas and groups. ${ }^{25}$ Organizations devoted to temperance, abolition, and religious instruction, for example, were based on the belief that humans were inherently good and that miscre- ants could be reformed through religious education and an environment that shielded them from corrupting influences. The Quakers' involvement in establishing prisons and asylums was based on their desire for the humane treatment of inmates and on an optimism in the power of reform, as was the expansion of Shakerism in the same period.

\section{Shaker Town Planning}

Meacham and Wright's search for order after the unstructured years under Mother Ann's guidance does not seem so unusual when viewed in the historical context of European settlement in America. Their plans for the complete organization of Shaker society - their version of utopia-permeated the layout and structure of the villages. Visitors passing through Shaker settlements in the late 1700s and early 1800 s never failed to comment on their unusual tidiness. Despite his generally negative opinion of Believers, Elkanah Watson noticed the order of the New Lebanon community during a visit in August 1790: "The village ... is built on one wide street, the houses neat and ... all painted a dull yellow." ${ }^{26}$ When traveling through New Lebanon in 1819, Benjamin Silliman marveled: "The utmost neatness is conspicuous in their fields, gardens, courtyards, out houses, and in the very road; not a weed, not a spot of filth, or any nuisance is suffered to exist. Their wood is cut and piled, in the most exact order; their fences are perfect; even their stone walls are constructed with great regularity." ${ }^{27}$ The linear plan and well-groomed grounds made the systemization underlying Shaker beliefs visible to visitors. ${ }^{28}$ Although both Watson and Silliman viewed the Shakers' religious and social practices negatively, they admired the control that reigned over their villages. This love of order belied the social roots shared by the Shakers and the larger society from which they came.

Finding models for the Shaker village is difficult because it appears to derive from a variety of sources. Having come predominantly from New England, the Eastern Shakers may have looked to that region's villages in planning their own communities. The circulation of the Millennial Laws in the early 1800 s coincided with the village green movement in New England towns, which cleared the squares of buildings, gravestones, and other structures in order to make the area more parklike. The Shakers took the idea further. Their strong sense of order in their temporal and spiritual lives pervaded all aspects of the village, and they introduced many of their own ideas into their community organization. ${ }^{29}$ The Shakers lacked a formalized method of planning settlements; nevertheless, the maintenance of order and neatness acted as a strong organizing 
force, as is evident in a section of the Millennial Laws entitled "Of Prudence Neatness and Good Economy":

2. It is considered good order, to lay out, and fence all kinds of lots, fields and gardens, in a square form, where it is practicable.

3. Buildings which get out of repair, should be repaired soon, or taken away, as is most proper.

4. No kind of filthy rubbish, may be left to remain around the dwelling houses or shops, nor in the dooryards, or streets in front of the dwelling houses or shops.

5. Every Saturday night, and Monday morning, the street opposite the meetinghouse, should be cleaned of rubbish and litter.

6. All of the gates should be closed on Saturday night and work rooms should be swept; the work and tools should be in order, and safely secured from thieves and fire. ${ }^{30}$

Some of the rules applied to the village's appearance specifically on Sunday, the primary day of worship. The need to clean up before the Sabbath had as much to do with the Shaker restriction against physical labor on that day as it did in presenting a clean village to outsiders who came to witness worship in the meetinghouse.

Neatness and order were intended to set the Shaker community apart from worldly towns. Emlen has noted that newly established Shaker villages did not seem significantly different from the farmsteads of non-Shakers, but that over time, as Shaker communities grew, they differed markedly in terms of size and large-scale physical improvements. Their form was determined by their role as part of a communal society. ${ }^{31}$ Swank's work on the Canterbury community demonstrates that the Shakers there located buildings in terms of functional zones along ministerial, residential, industrial, and agricultural axes. Swank argues that the Shakers devised new templates, leading to village plans that were quite different from traditional town plans in New York and New England. ${ }^{32}$ To facilitate communication among members and enhance work efficiency, Shaker buildings were usually set much closer together than in non-Shaker settlements, so that Shaker elders would be better able to supervise the community. ${ }^{33}$ Another distinction was the high degree of specialization of Shaker structures, especially as the group's economic interests expanded. In time, their villages had tanning houses, seed shops, spinning shops, herb houses, and laundry buildings. Later the Shakers constructed separate workshops for the sisters, brothers, and ministry. All these buildings played a vital role in supporting a prosperous but highly controlled communal society.

Yet, unlike monasteries or other later planned communities, Shaker villages were not developed according to a cohe- sive program, even after the establishment of the Millennial Laws. ${ }^{34}$ The laws do not include rules for town planning, nor are such plans discussed in any of the Shaker journals. For example, the Shakers did not use modules, as in the plan of St. Gall, Switzerland, or an extensive grid system, as in Old Salem, North Carolina, or Economy, Pennsylvania, to locate their buildings. Instead, in most villages major structures were situated along the main street or roads that ran through each family's community of buildings, resulting in a linear arrangement of the most important edifices-the meetinghouse, dwelling houses, and workshops-with secondary rows for supporting ones, as seen in an engraving of the Shaker village in Alfred, Maine (see Figure 1). At a few settlements, such as those in Watervliet and Canterbury, the Shakers arranged the main buildings on a short lane set perpendicular to the main road. ${ }^{35}$ Practical concerns governed their placement: first, the structures where most members lived, worked, and worshiped stood adjacent to one another; second, the community had excellent access to trading routes to boost sales of their products. The layout had its ideological basis in its display of order and increasing prosperity to travelers and traders passing along the thoroughfare, thereby showing the world that the Shaker way of life led to both salvation and profit. The Shakers chose their sites carefully to promote interaction and trade with outsiders. This interaction was particularly important during the Second Great Awakening, when the Shakers successfully sought and gained new converts, resulting in a large increase in the sect's population.

\section{Dwelling Houses}

Shaker villages throughout the United States took shape as members erected buildings during the early nineteenth century. The edifices of the main family housed the most elect members of the society and stood in the center of the entire community. Not only was the meetinghouse situated here, but also other communal structures such as the office, store, and schoolhouse. All the other families were founded and named in relation to the Church or Center Family. Each group had a cluster of buildings, usually one or two dwelling houses, workshops, a barn, and a laundry.

Whereas the physical and spiritual center of the entire village was the meetinghouse, the social center of each family was the main dwelling house, as can be seen in the 1939 Historic American Buildings Survey (HABS) plan of New Lebanon (Figure 2). The dwellings, the largest buildings in the community, stood as the symbols of family unity and conformity. The bell atop each one rang out the times of rising, eating, worshiping, and retiring to bed.

Dolores Hayden has studied the Hancock, Massachu- 


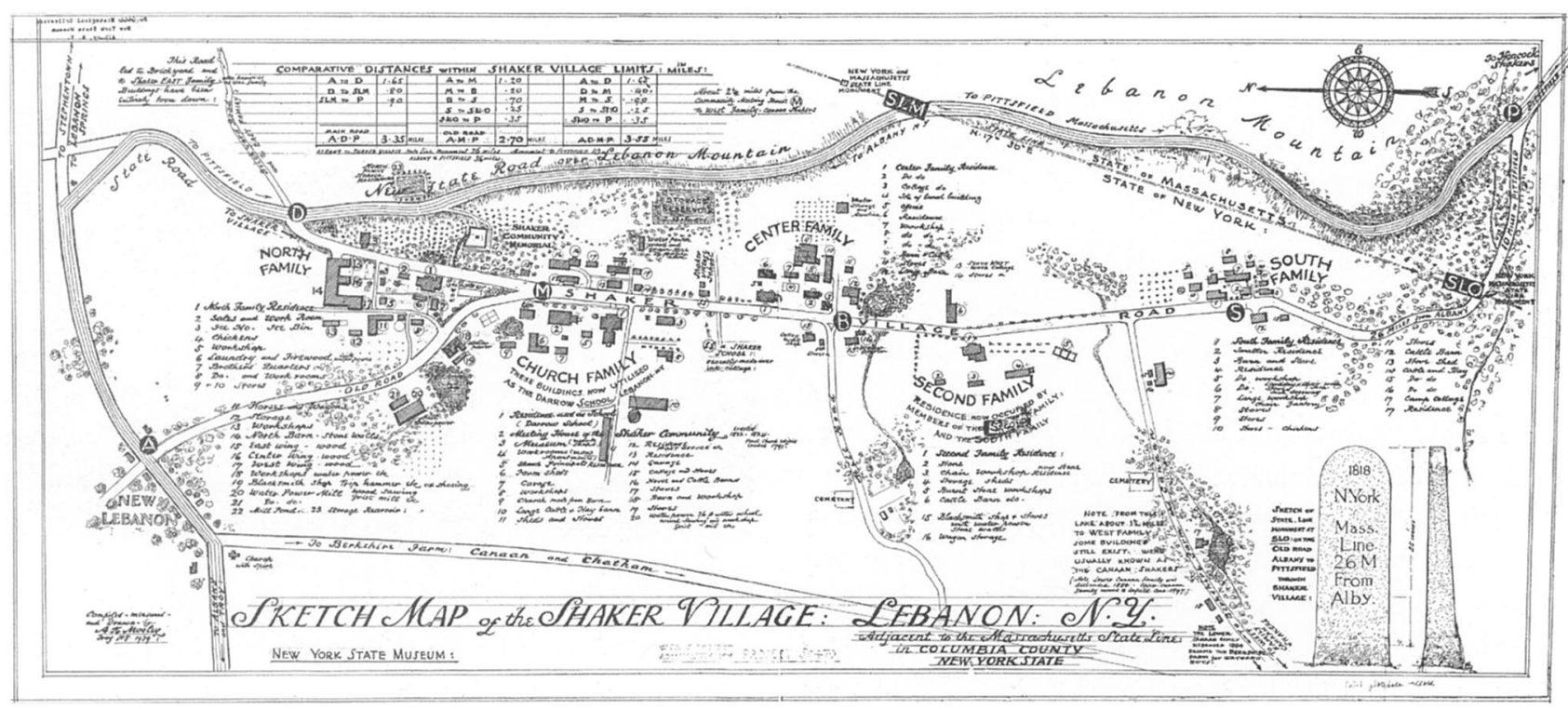

Figure 2 "Sketch Map of the Shaker Village: Lebanon, N.Y.," 1939. Drawn by A. K. Moseley, Historic American Buildings Survey

setts, community in order to understand why the Shakers were successful in establishing a communal system that could be replicated in places as different as Maine and Kentucky. For her, the answer lies in the Shakers' ability to balance the earthly and heavenly spheres, which Shaker belief encompassed. By manipulating the sense of personal space and areas of movement, Shaker leaders were able to create an environment that represented dual spheres. ${ }^{36}$ Thus, regulations requiring specific physical distances between men and women emphasized the spiritual need for celibacy.

The search for spiritual order pervaded all aspects of daily life. Table monitors in the dining rooms reminded members to maintain standards of economy and good manners: "First, All should sit upright at the table. . . When you take a piece of bread, take a whole piece ... and when you cut meat, cut it square \& equal." ${ }^{\prime 3}$ The Millennial Laws further enforced order, for example: "Retire to rest in the fear of God, without any playing, or boisterous laughing, and lie straight." ${ }^{38}$ A series of rules under the section "Orders concerning Intercourse between the Sexes" forbade brethren and sisters to pass each other on the stairs or to shake hands. Nor could brothers and sisters meet alone or whisper together in conversation. ${ }^{39}$ The ministry attempted to reinforce these regulations in the meetinghouse and dwellings, where separate entrances and stairways helped men and women keep physical distances. In religious worship, this segregation was maintained. Brothers sat on one side of the meetinghouse, across from the sisters. The dances devised by Meacham to replace the free ecstatic worship under Mother Ann required carefully rehearsed steps to be carried out in a precise order. Men and women danced in ranks performing the same movements, aided by pegs and nails embedded in the floor to guide their steps. ${ }^{40}$ Only during internal periods of religious revival, such as that known as Mother Ann's Work (1837-45), were members allowed to break ranks and dance and whirl as the spirit moved them.

The leaders intended these measures to promote the differences between the Shakers and worldly society. Rosabeth Moss Kanter described the intentional quality of communal societies as being very important. ${ }^{41}$ As did many utopian groups, the Shakers had a clear legal definition, the covenant, that was recognized by the community as well as the larger society, establishing their sect as part of the world, but also separate from it. Opposed to the idea of intentional communities is the sociological concept of isomorphism, which "refers to the structural similarity between the community and its environment." ${ }^{\prime 2}$ Such similarities include language, means of exchange, and cultural symbols. Isomorphism allowed the Shakers to maintain economic and social ties to the world, enabling the community to prosper through its interaction with rather than isolation from mainstream society. Obviously isomorphism can create social difficulties for the community if too much interaction is permitted. The Shakers' increased links with the world in the late nineteenth century gradually eroded their unique identity, destroying the sense of community that had attracted so many converts in the early part of the sect's history. 
The dwelling houses were the physical locus of Shaker communal life. Because the dwellings were central to Shaker life, they were also the most important in shaping the behavior of sect members. All residents took their meals and worshipped there during the week and sometimes on winter Sabbaths when the cold weather prevented attendance in the main meetinghouse at the Church or Center Family. Members conducted social activities such as meetings and lectures in the dining, sitting, and retiring rooms. Many chores were performed in the dwellings as well, including cooking, sewing, and the production of fancy goods that the sisters made for sale in the Shaker office and store.

When the New Lebanon Shakers officially gathered in 1787 , they lived in preexisting farmhouses, as was common in other early Shaker communities. From 1787 to 1792, they built six new houses to accommodate the rapidly increasing number of converts. In his 1856 history of New Lebanon, Isaac Newton Youngs, a member of the Church Family and one of the most prolific chroniclers of Shaker life in the early 1800 s, described these early structures as "generally built quite contracted, with but little hall room, and with crowded and steep stairs." ${ }^{33} \mathrm{He}$ noted that the early Shakers were inexperienced in the basics of house construction and, thus, relied on many non-Believers to assist in the framing and roofing of dwellings. ${ }^{44}$ Although some scholars dispute this assessment, it is clear that the Shakers began building much larger, more spacious dwellings in the early nineteenth century and turned to local forms of domestic architecture as models. ${ }^{45}$

Although none of the early houses exists in its original state, Shaker village views and descriptions from journals and other accounts suggest that they looked much like the early meetinghouses constructed in the eastern communities. The Shirley, Massachusetts, meetinghouse, built in 1793 and now located at Hancock Shaker Village, provides one example of early Shaker architecture (Figure 3). The earliest dwellings, built in the 1700s, were modest woodframe buildings with gambrel roofs. Such houses mirrored the surrounding rural architecture of the Anglo-Dutch Hudson River valley. According to Youngs, at this time the Shakers were more concerned with survival than with creating a distinct building style. As the Shakers grew in number and became more prosperous and unified, however, they looked more closely at many aspects of their society, including their houses, and they began construction programs to enlarge and regularize the forms of their abodes.

During the early 1800 s, the new houses helped maintain order in daily activities and emphasize the concept of communal life and worship. The structures became one of the most recognizable building types of a Shaker village.

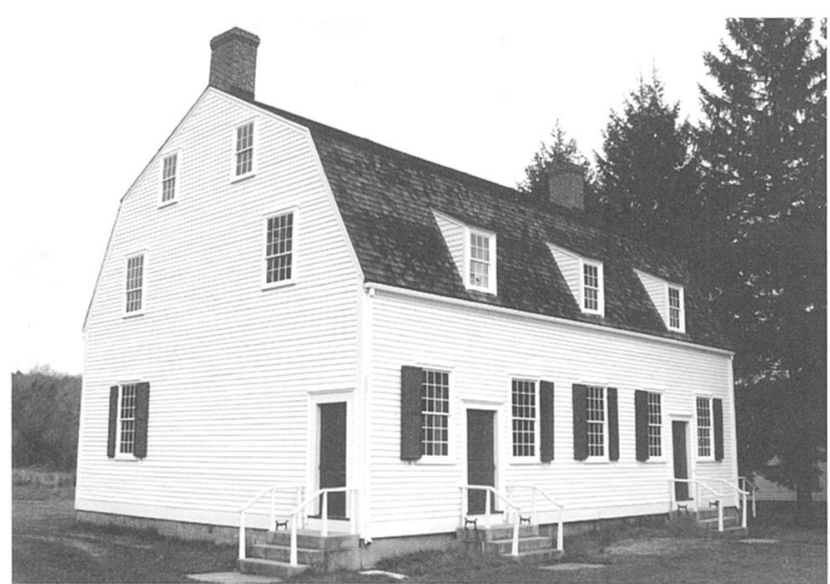

Figure 3 Meetinghouse from Shirley, Massachusetts, 1792-93, moved in 1962 to Hancock Shaker Village, Massachusetts

Large and boxy, they accommodated from thirty to one hundred men and women, while maintaining the Shaker ideal of celibacy. The basis for housing this many inhabitants is not clearly documented. Edward Deming Andrews, citing Arthur Baker, stated that "experience proved that the ideal size was about fifty members: if larger, 'the energy evoked by the communal system was apt to be dissipated over so wide an area' ... if much smaller, the advantages of combination and division of labor were to a degree lost." ${ }^{46}$ Larger numbers of Shakers allowed for the duplication of interior features such as separate staircases, hallways, and sitting rooms for the brothers and sisters to ensure that the two sexes would not meet within the house except at organized meetings, for meals, and for worship. The dwellings allowed communal work and worship, but also kept the number of residents manageable so that the elders could maintain control and supervision.

The regulation of time was another means of keeping order. Brothers and sisters functioned under strict schedules that reflected more the time-organization of early factories than the schedule of a rural communal society. "Orders concerning rising in the Morning and retiring to Rest at Night" listed the following selected rules:

All are required to rise in the morning at the signal given for that purpose; and when any rise before the usual time they must not be noisy.

2. Brethren should leave their rooms, within fifteen minutes after the signal time of rising in the morning, unless prevented by sickness or infirmity.

3. Sisters must not go to brethren's rooms, to do chores, until twenty minutes after the signal time of rising in the morning. ... 
7. No one may sit up after the usual time of retiring to rest, to work, read, write, or any thing of the kind, without liberty from the Elders, and the knowledge of those who have the care of the room where they lodge. ${ }^{47}$

These exact time periods, "within fifteen minutes," "until twenty minutes," kept members poised to stay on top of the day's work and separated men and women.

The strict division of time added another dimension to the control mechanisms that were gradually imbedded in Shaker life. Economic and productive scheduling was considered an excellent way to demonstrate one's love for community and for God. Countless testimonies and histories of Mother Ann attribute two famous sayings to her: "Hands to work, hearts to God" and "Do all your work as though you had a thousand years to live, and as if you knew you must die tomorrow." The wise use of time also extracted the most labor from a large group of workers, a vital requirement for the Shakers' prosperity.

The Shakers built large dwelling houses instead of small ones for many reasons. First, the social and religious organization of the Shaker community required that members live together in large units rather than smaller ones. The foundation and stability of the community relied on the subordination of the individual to the group. Members living together in sizable dwellings were forced to come in contact with many other members of the family, which required a great deal of patience and cooperation from all inhabitants.

Second, sheltering more people under one roof was more economical than providing the same number with several smaller houses. In addition, having many people live together made a variety of chores easier to perform. ${ }^{48}$ The Shakers' morning schedule required that everyone rise at 4:30 A.M. in the summer and 5:30 A.M. in the winter. While brethren performed the early morning jobs like milking the cows, the sisters went into each dwelling room, aired the spaces, made the beds, and swept the floors. Other sisters went downstairs to the kitchen to prepare breakfast. One hour later, everyone was ready to meet in the dining room for the day's first meal, having already accomplished many tasks.

Third, the various dwellings were used to classify members of the society, usually by age and by religious commitment. This worked in a number of ways. For instance, the Shakers believed that children should live in their own order, apart from other members except for a Shaker brother or sister who served as their guardian. Children could thus be indoctrinated more easily into the Shaker way of life. Furthermore, separation isolated the most perfect
Shakers, the First Order, and supposedly allowed them to follow the Millennial Laws without being corrupted by newer, less fervent members.

Fourth, and most important, the family elders and eldresses could more conveniently keep watch over all the members if they were living under the same roof. Rarely was a Shaker alone in the dwelling house. Privacy was unknown. By constructing large dwellings, the ministry ensured that a majority of the Believers lived in a house built to implement the Millennial Laws. It was therefore possible to reform and educate many people at the same time.

\section{An Architecture of Control}

In the next three decades, the central ministry in New Lebanon attempted to standardize the arrangement of space within Shaker houses, and they largely succeeded. The laws regulating dwellings, originated by Meacham and Wright and written down, enforced, and altered by later members of the ministry, resulted from a practical approach to ensure the society's survival. Not only did the elders wish to keep all members on the road to perfection, but they also wanted to maximize efficiency in producing goods. Throughout their history, the Shakers sought to balance their community's temporal and spiritual needs.

During the early 1800s, the Shakers enlarged most of their late eighteenth-century dwellings and constructed many new ones. These changes allowed for the accommodation of new converts and enabled the ministry better to implement its rules concerning the separation of the sexes and the behavior of members within dwellings. The increased space provided more room for required elements of Shaker houses-separate stairways and halls for men and women, a dining room, and a large meeting room left free of supports so that the Shakers could perform their dances. The rooms of family elders and deacons could be placed near entrances and other busy areas to permit better supervision of inhabitants. Tasks could also be better organized by housing members who worked together in the same rooms.

Whereas many of the eastern dwelling houses were built of wood or, in some cases, of brick, other buildings in New England and many in the West were constructed of stone; these conveyed a strong sense of permanence and authority akin to the intended character of many institutional structures of the same era. When the Enfield, New Hampshire, Shakers decided to build a massive granite dwelling house, they turned to a professional architect, Ammi B. Young, rather than attempt to do the work themselves, having no trained stonemasons among their mem- 


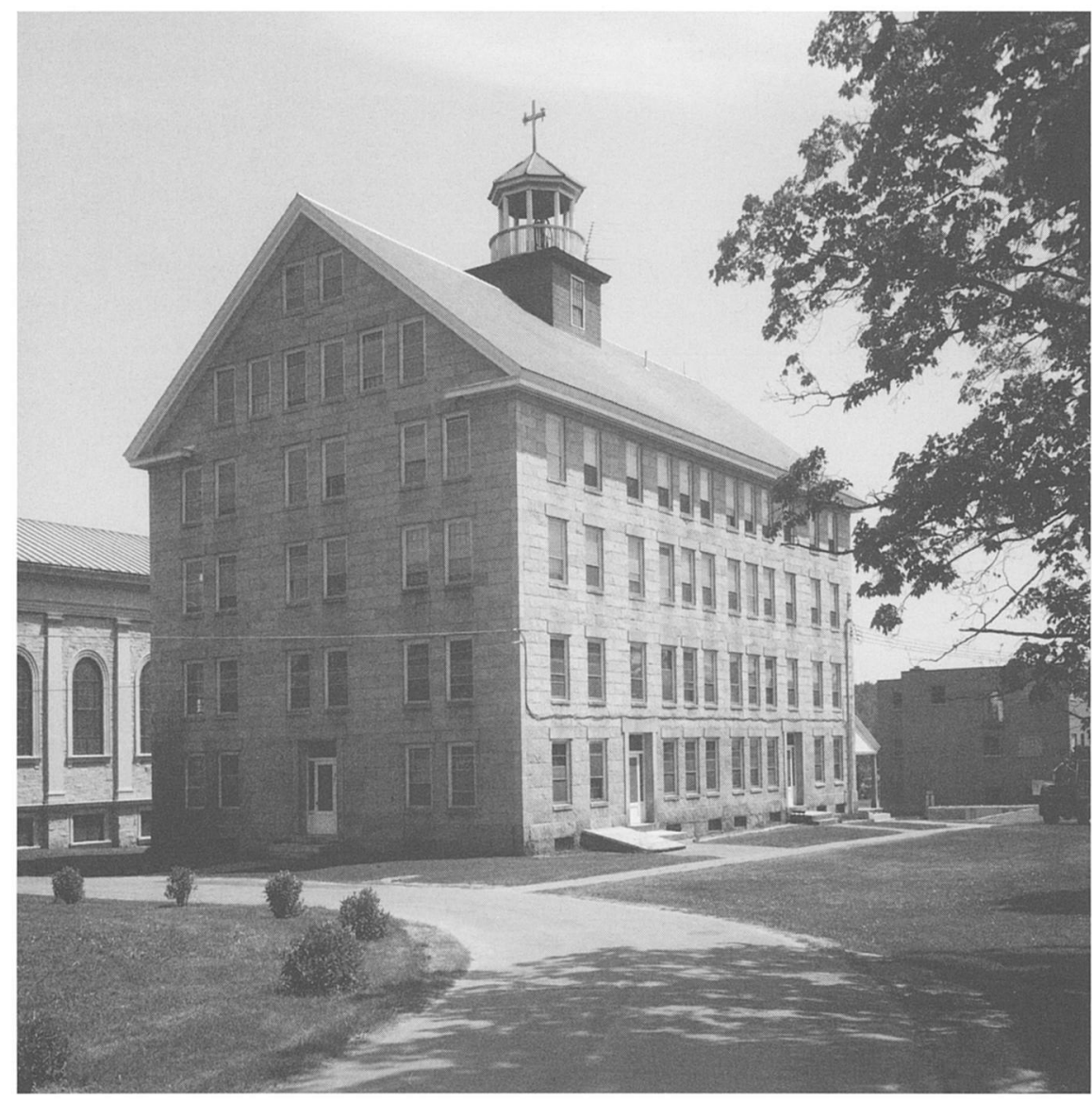

Figure 4 Great Stone Dwelling House, Enfield, New Hampshire, 1837-41. The cupola is a later addition. Photograph by Elmer R. Pearson, 1971, Historic American Buildings Survey

bers. ${ }^{49}$ Young was a natural choice; he had designed the Vermont State Capitol in Montpelier, but more important, he had experience designing dormitories, most notably Wentworth Hall (1828) at Dartmouth College, in nearby Hanover. ${ }^{50}$ Built between 1837 and 1841, the Shaker dwelling was inspired by the Greek Revival style with a gable roof and little ornamentation except for gable end returns and flat granite lintels over the windows and doors (Figures 4-6). Inside, the wide central hallway accommodated two staircases at either end of the building, as well as a large dining room with freestanding columns and a meeting room above (the four columns shown on the plan in Figure 6 were added in the twentieth century), each with separate entrances for brothers and sisters. Numerous retiring rooms housed men and women at opposite ends of the house.

In the western communities, dwellings departed to some extent from eastern standards by drawing on regional materials and architectural forms. At Pleasant Hill, Kentucky, the third largest Shaker village after New Lebanon and Union Village, Ohio, the Shakers erected a number of houses in stone or brick for the community's families. In particular, the dwellings constructed in the 1820 s and 1830 s tend to be larger and more elaborate than those in the East of the same era. Many of them include kitchen ells that extend from the back of the buildings (Figure 7). These ells evolved from detached kitchens, known as summer kitchens, which were set behind the main house and were common in the South and Midwest. In addition to influencing the construction of separate kitchens, the warmer climate of the South shaped other aspects of Shaker architecture in Kentucky, such as the incorporation of large windows, high ceilings, and exceptionally wide hallways to facilitate air circulation (Figure 8). Micajah Burnett, a trustee of Pleasant Hill who supervised many of the community's construction projects, is largely responsible for the worldly elegance of many of the western dwellings. $\mathrm{He}$ combined Shaker requirements for order and dual spaces for men and women with the architectural forms and details of the Federal style as they appeared in nearby public and institutional buildings, such as the Old State Capitol in Frankfort, Kentucky. The Center Family's third dwelling, constructed of limestone between 1824 and 1834, combines classicizing elements including arched ceilings in the hall- 

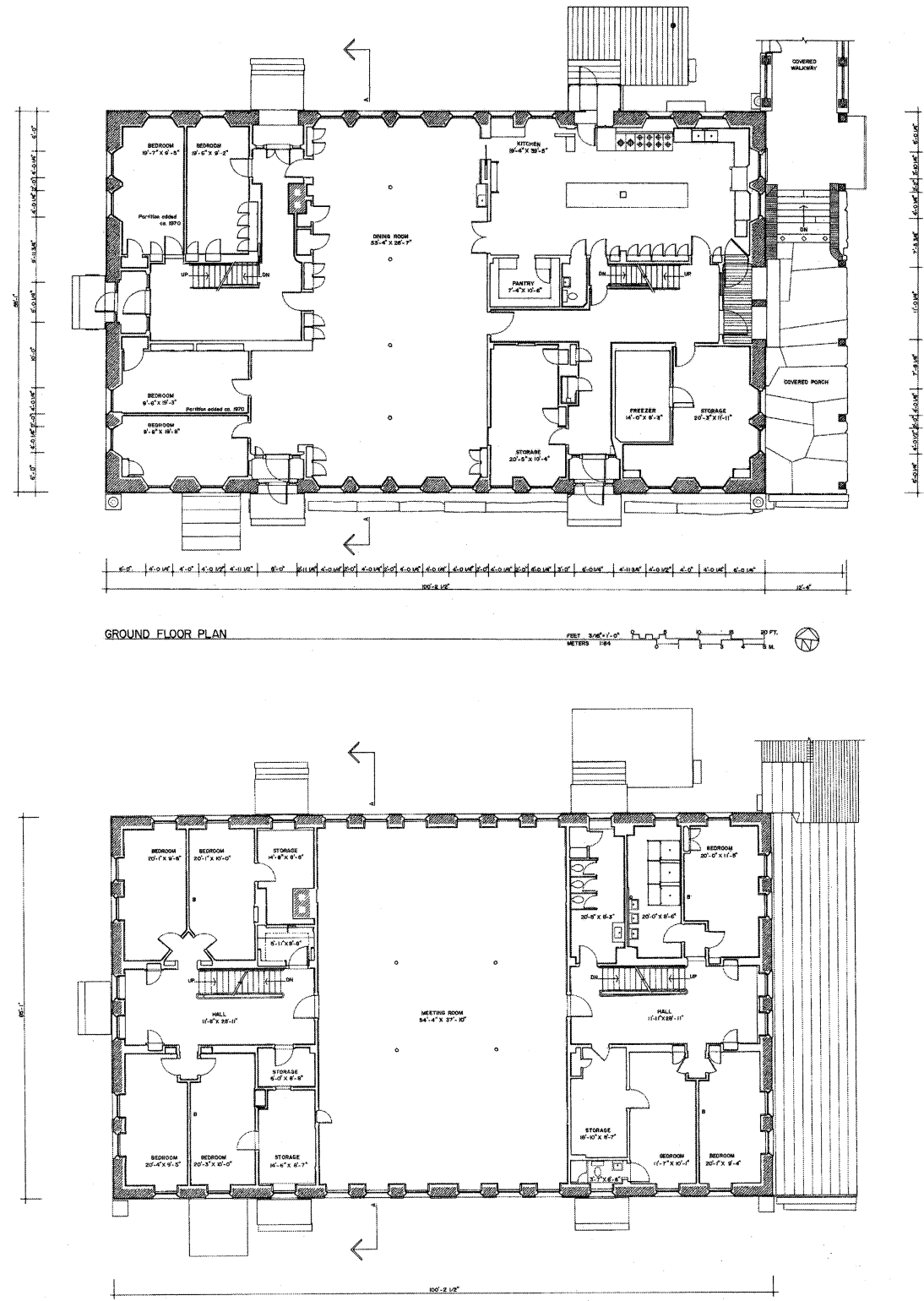

Figure 5 Ground-floor plan, Great Stone Dwelling House, Enfield, 1978. Plan by Patrick M. Burkhart, Historic American Buildings Survey

Figure 6 Second-floor plan, Great Stone Dwelling House, Enfield, 1978. Plan by Janet L. Hochuli, Historic American Buildings Survey ways and meeting room (Figure 9), Tuscan columns in the dining room, and painted blue moldings throughout to provide a sense of unity and refinement to the building. Such elements would have been expected in large public buildings of the period, but double entrances leading into a central hall that contains separate staircases marked the structure as a Shaker building.

Windows could, of course, function as a mode of surveillance. Shaker leaders, who lived on the upper floor of the meetinghouses in the late 1700 s and early 1800 s to keep apart from the main body of Shakers, used interior windows to watch worship meetings. In the Pleasant Hill meetinghouse, built in 1820, two small windows pierce the wall between the main meeting space and the ministry's quar- ters. ${ }^{51}$ In 1824 , the New Lebanon Shakers completed their second meetinghouse, an enormous structure with a gracefully curved roof (it replaced the original meetinghouse, which the community had outgrown). In 1851, the ministry had four small louvered windows added to the south wall between the worship area and their quarters so that the elders and eldresses could watch services unobserved (Figure 10)..$^{52}$ Swank notes that even the numerous large windows of the dwelling houses served a monitoring function. Traditionally left uncovered, they "were practical devices for controlling light, an aesthetic expression of Shaker design, and reinforcers of community order." ${ }^{\prime 3}$

The standard arrangement of space in these dwellings differed only slightly from that of the early houses and var- 

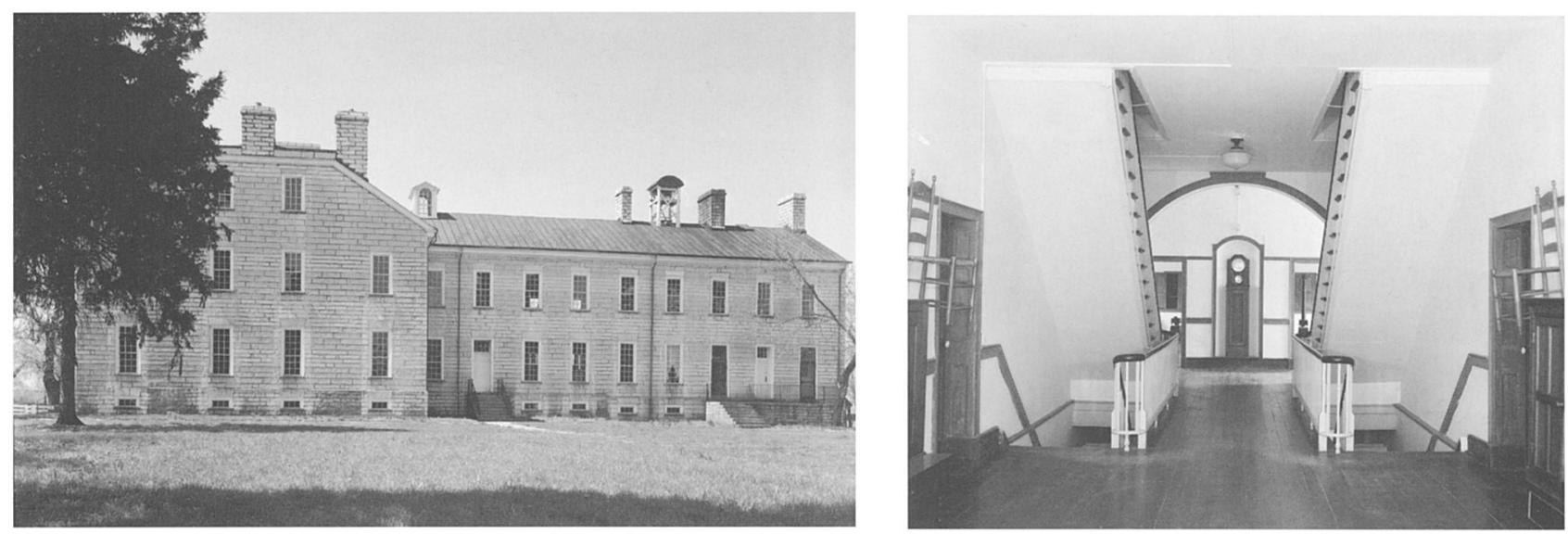

Figure 7 Center Family Dwelling House, Pleasant Hill, Kentucky, 1824-34. Photograph by Jack E. Boucher, 1963, Historic American Buildings Survey

Figure 8 Front hall, second floor, Center Family Dwelling House, South Union, Kentucky, 1822-33. Photograph by Elmer R. Pearson, 1972, Historic American Buildings Survey

ied little from community to community. The HABS plans of the New Lebanon North Family's main dwelling (Figure 11) record a typical layout. The basement was used for food storage and preparation. In many dwellings, the dining room was located on the same level as the kitchen to make the serving of meals efficient. Such was the arrangement at Enfield's Great Stone Dwelling, Pleasant Hill's Center Family dwelling, and New Lebanon's North Family and South Family dwellings (Figures 12-14). As is noted on the North Family dwelling plan, visitors and hired help ate in separate dining rooms. Elsewhere, however, such as the brick dwelling in Hancock, the dining room was on the floor above the kitchen, either at one end of the house or in a rear ell. In these cases, the room was located directly above the kitchen, and dumbwaiters moved food between the two levels. ${ }^{54}$ This setup kept the hot and noisy activities of food preparation below ground in the cool cellar, without requiring the sisters who worked in the kitchen to run up and down the stairs at meal times.

The first floor, the most active area of the house, had many common rooms (Figure 15). After the 1845 construction of the addition to the North Family's dwelling, which expanded the house to the north, men and women had their own front entrances. Stairways corresponded to these entryways, roughly dividing the building into three sections: one accommodated the brothers; another housed the sisters; and the center space generally housed the deacons and elders. Families installed separate entrances and
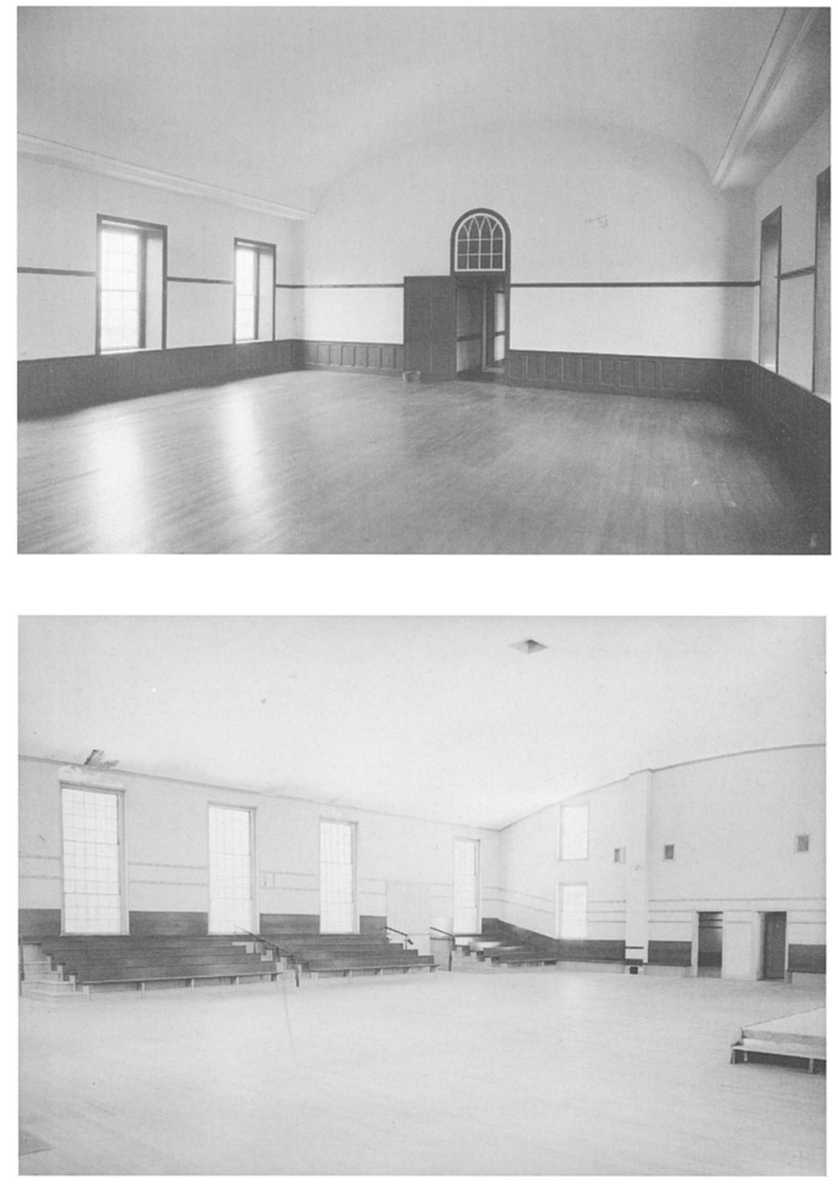

Figure 9 Meeting room, Center Family Dwelling House, Pleasant Hill. Photograph by Jack E. Boucher, 1963, Historic American Buildings Survey

Figure 10 Interior with louvered windows (at right), Church Family Meetinghouse, New Lebanon, New York. Meetinghouse, 1822-24; windows, 1851. Historic American Buildings Survey 


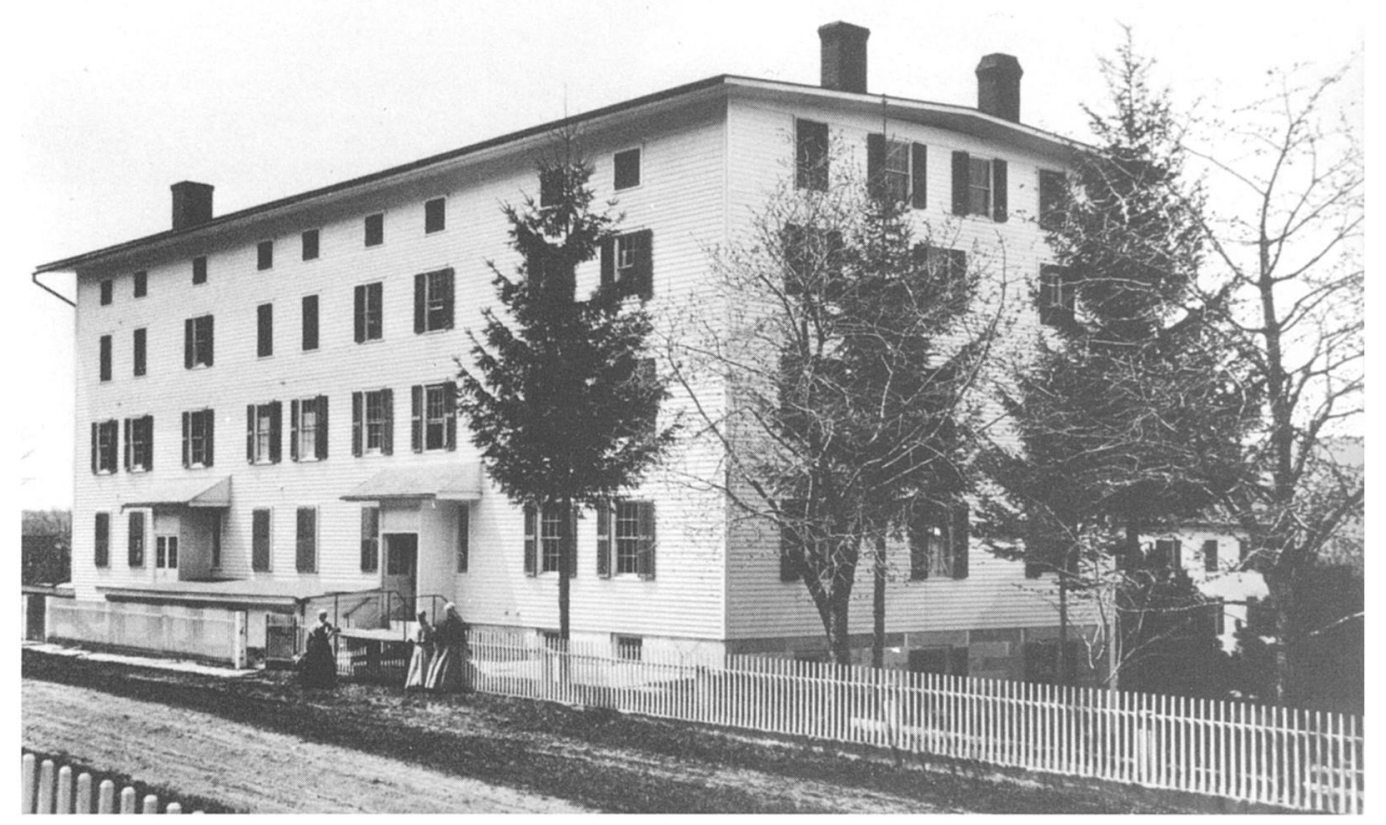

Figure 11 First Dwelling House, North Family, New Lebanon, 1818; enlarged 1845, 1863; demolished 1973. Undated photograph

Figure 12 Basement-floor plan, First Dwelling House, North Family, New Lebanon, 1939. Plan by A. K. Moseley, Historic American Buildings Survey

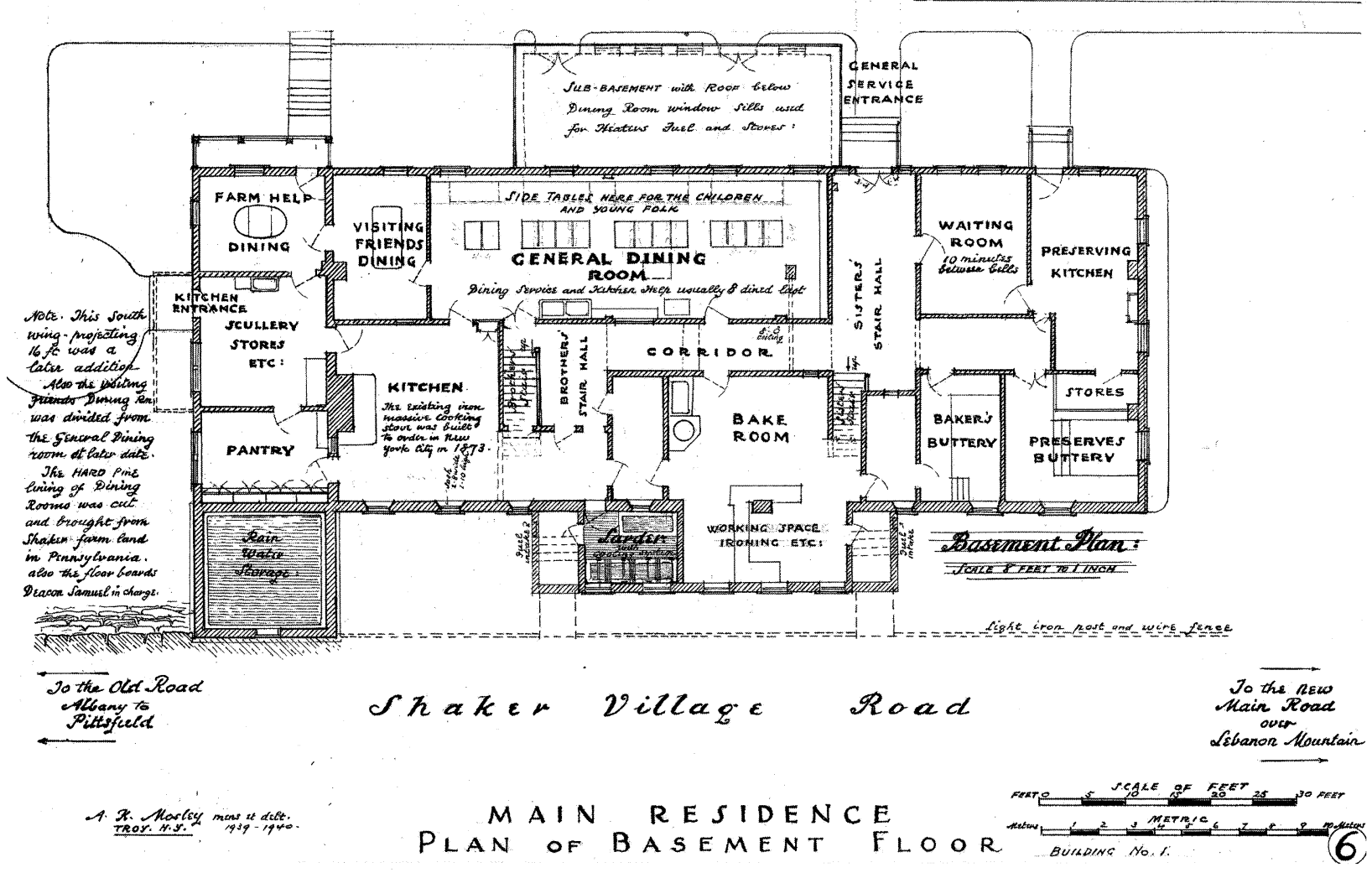




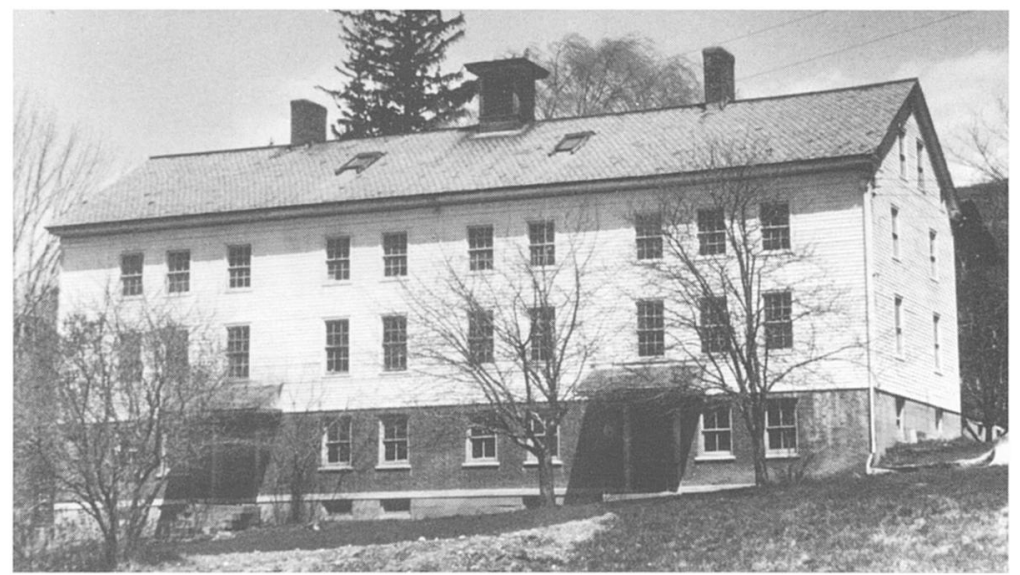

Figure 13 Dwelling House, South Family, New Lebanon, by 1831 . Undated photograph

Figure 14 Basement-floor plan, Dwelling House, South Family, New Lebanon, 1942. Plan by L. G. Wands, Historic American Buildings Survey

Figure 15 First-floor plan, First Dwelling House, North Family, New Lebanon, 1939. Plan by A. K. Moseley, Historic American Buildings Survey
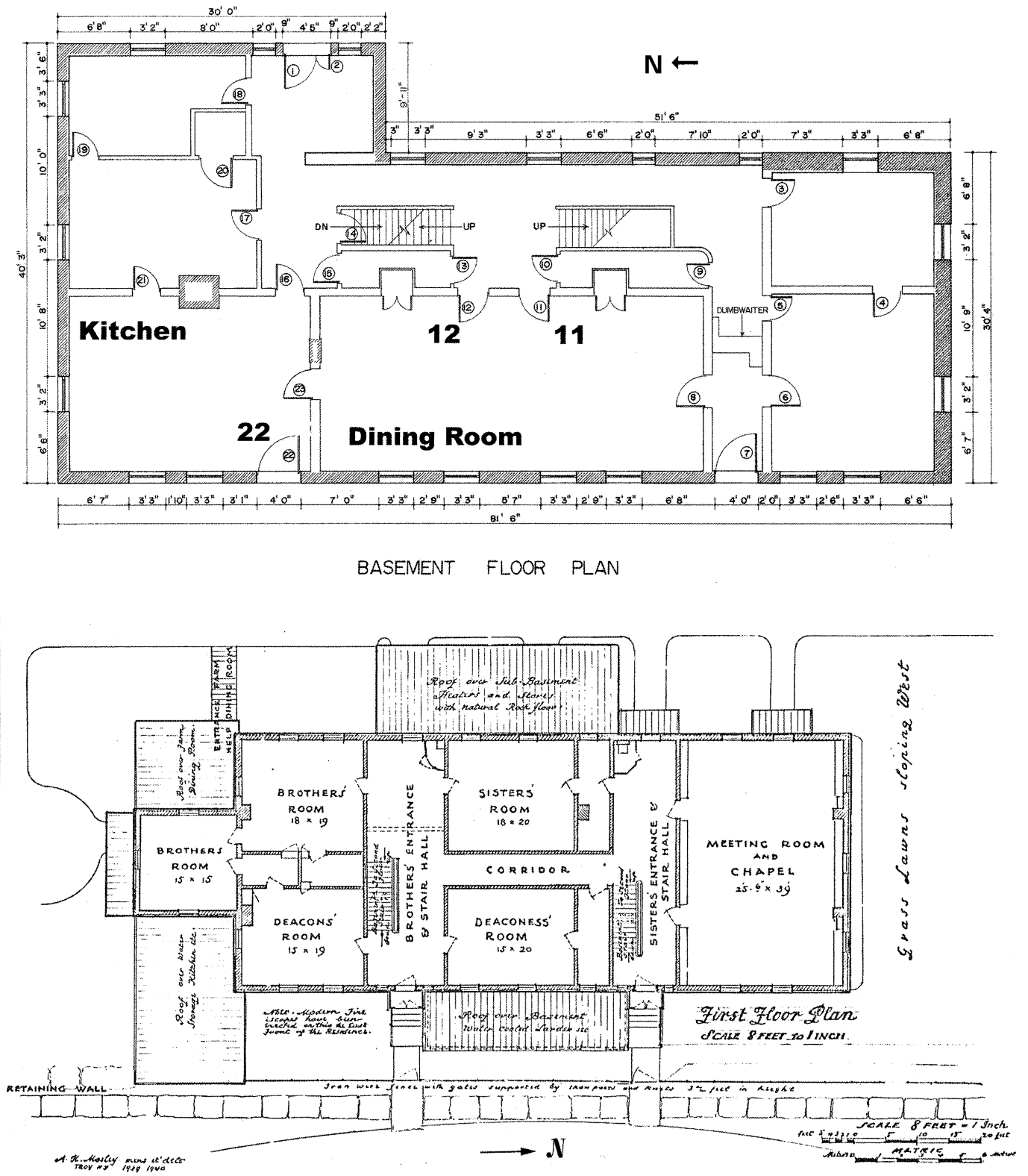


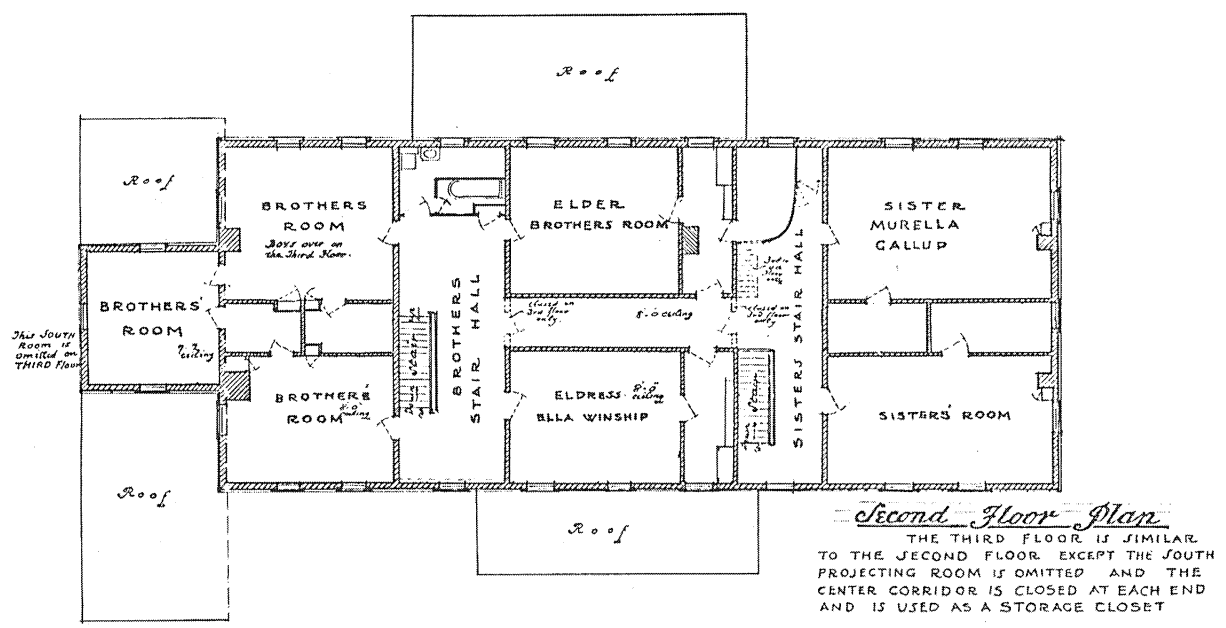
PROJECTING ROOM IS OMITTED AND THE
CENTER CORRIDOR IS CLOSED ATEACHEND
AND IS USED AS A STORACE TLOSET
Figure 16 Second- and third-

floor plan, First Dwelling

House, North Family, New

Lebanon, 1939. Plan by A. K.

Moseley, Historic American

Buildings Survey

Figure 17 "Shaker Buildings in New Lebanon." The Great House of the Church Family is on the left; the Meetinghouse is on the right. From John Warner Barber, Historical Collections of the State of New York (New York, 1851), 78

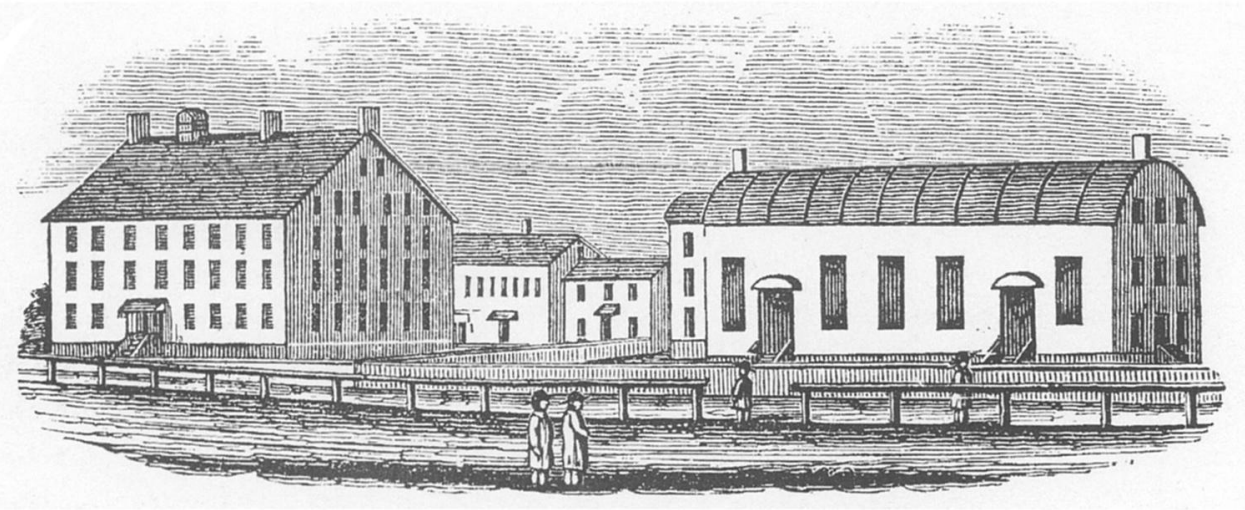

areas for brothers and sisters in all their old and new dwellings in the early 1800 s.

The upper levels of the house contained the members' retiring rooms (Figure 16). Again, brothers' rooms were on one side, sisters' quarters on the other, and elders' and eldresses' units in the center. The division of space between the sexes varied from house to house. In some cases, the two groups were placed at either end of the building, as in the North Family's main dwelling. In other structures, such as the New Lebanon Church Family's Great House (Figure 17) or Hancock's brick dwelling, men and women lived in rooms on the same floor, across the hall from one another.

Division of the sexes was not absolute; instead it was meant to present a constant reminder to all Shakers of the rule of celibacy. Few elders wanted the kind of distance that was characteristic of monasteries. The historian Henri Desroche asserted that the Shakers disliked monasticism because its selectivity excused the rest of the population from leading the apostolic life..$^{55}$ The Shakers believed everyone should follow Christ on the path to perfection and salvation.
With the enlargement of old dwellings and the construction of new ones, the elders were able to design interior space in ways that would make it easier to maintain control over the brothers and sisters and to regulate their movement. Floor plans of the New Lebanon South Family's dwelling house show how hallways, doorways, and walls restricted circulation between various rooms. The core of the dwelling was built sometime before 1831. In that year, a major renovation enlarged the building. Thereafter, the family journals record no major building activity for the house, so we can assume its exterior and interior layout changed little while it was owned by the Shakers. The HABS drawings documenting the interior were made in 1942, shortly after the Shakers had vacated the South Family's cluster of buildings.

The basement contains the kitchen, dining room, and separate entrances (see Figure 14). Although the plans do not specify entrances, stairways, and sitting rooms for the brothers and sisters, the women's entrance is most likely door 22, leading into the kitchen, where women rather than men worked. Hence, the sisters' stairway is on the left side 


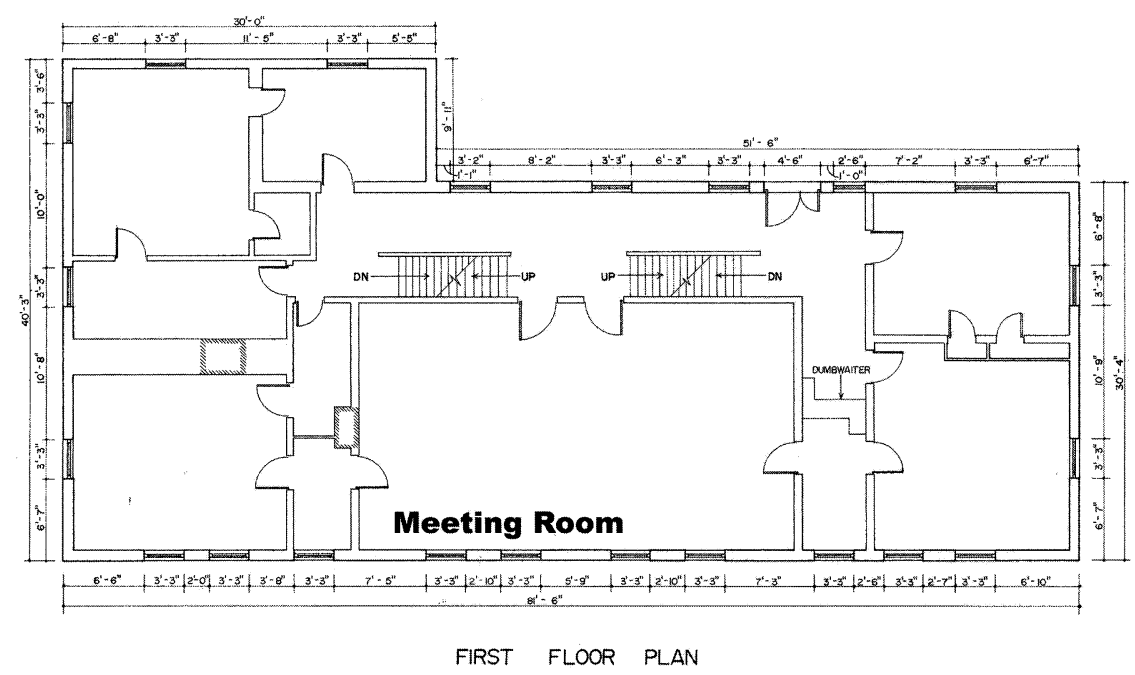

Figure 18 First-floor plan, Dwelling House, South Family, New Lebanon, 1942. Plan by L. G. Wands, Historic American Buildings Survey

of the house; the brothers' stair is on the right, corresponding to their entrance. Neither entrance leads directly into a main hall. The sisters had to cross the kitchen or both the kitchen and the dining room to reach their staircase. The brothers had to go through the dining room or a room on the right to reach their stair, as the direct way to the main hall is blocked by a dumbwaiter. No one could enter or leave the house unseen as long as the other two rooms were occupied. The kitchen, of course, would have been occupied for much of the family's waking hours since food preparation was an ongoing process. If we use floor plans of other dwellings as a guide, the room at the southwest corner of the house (at lower right) was probably the deacons' room. The brothers, therefore, could not have entered the house unnoticed either. Access to the dining room for meals was controlled as well. Sisters entered through door 12, while brothers used door 11 .

On the first floor, the spatial arrangement restricted movement in a similar way (Figure 18). Brothers and sisters could come into the meeting room directly only by going through their respective doors near their respective stairways. The two narrow hallways flanking the meeting room were blocked, on one side by a thin partition, on the other side by a dumbwaiter. Entrance into the meeting room through its side doors was possible only by passing through the two rooms at the front of the house, which could have been used as sitting rooms, the sisters' area on the left, the brothers' on the right.

The segmentation of space emphasized the codes of behavior and movement recorded in the Millennial Laws. Among these were "Orders concerning the Language of Believers," "Orders concerning rising in the Morning and retiring to Rest at Night," and "Orders concerning Attending to Meals, Eating, \&c. \&c." The orders shaped the way members carried themselves, spoke, dressed, and acted. The architecture of the dwellings kept them constantly aware of where they were and how they should behave.

The wave of dwelling house construction allowed the elders to better supervise inhabitants through the strict control of the number of persons per room. For example, the 1831-32 enlargement of the Great House (built in 1788; burned 1875) in New Lebanon provided sixteen retiring rooms for all the inhabitants. ${ }^{56}$ Elders, trustees, and deacons were paired with a fellow leader and assigned to specific rooms. When an individual ceased being a deacon or elder, he or she moved into a different room. In the rest of the retiring rooms, the number of inhabitants ranged between four and eight. The elders felt these numbers to be desirable because roommates could work in teams and keep an eye on one another. The elders carefully orchestrated the organization of retiring rooms and the placement of Shakers in each room. In the 1830s and 1840s especially, numerous "great moves" took place along with many other smaller moves that constantly shifted Shakers from room to room, house to house, and job to job. The intention was to prevent residents from forming deep personal relationships with each other and to keep natural family members apart as much as possible. In addition, the frequent changing of duties among brothers and sisters required individuals to live with those who had similar jobs so they could work more productively and efficiently. For example, on 14 January 1854, Peter Long and Charles Sizer exchanged residences. "Peter moved from the Office \& took Charles Sizer's place in the family Deacon's room N 1. and Charles 
went to the Office, to occupy in the line of business that Peter has. ${ }^{57}$ Other changes were more routine. Sisters worked in the kitchen for three-month intervals, and often during that time they lived together in retiring rooms. The system made the preparation of meals more efficient because all cooks kept the same schedule.

Even the elders lived under this system. When an elder or eldress resigned, he or she moved from the elders' rooms and into a retiring room with brothers or sisters. The replacement moved from a retiring room into the elders' quarters. Finally, newcomers, attrition, sickness, and death affected the makeup of a dwelling house's population. In February 1837, Elisha Blakeman of New Lebanon's Church Family noted that "in consequence of the late deaths [one brother and three sisters had died recently], a great move takes place to day in our Order. Twenty-five persons change their place of residence. ${ }^{" 8}$ Boys and girls left the children's quarters for one of the main dwelling houses when they turned fourteen. At this age, they were expected to take on adult duties even though they would not become full Shakers until they were eighteen, when they could sign the covenant. At the same time, a constant stream of members ran off, abandoning roommates and coworkers, forcing the elders to find people to fill their jobs. If a member became seriously ill, he or she was moved to the infirmary or even quarantined in a small building called the Martin's Box, located near the New Lebanon Great House. When the individual was ready to return to work, he or she could move back to the dwelling house. This system of moves kept members in a state of flux and removed another aspect of control from their grasp.

Despite the measures taken to prevent close relationships, particularly among natural family members, many personal connections remained intact and new ones developed. Although Meacham's belief that all natural familial ties had to be severed, exceptions were often made in the nineteenth century. Members who had brought their entire family into the Shaker community were periodically allowed to visit their young children, if they were living in separate families. In some cases, children lived in the same family as their natural parents: "little Semantha Reynolds was taken by her mother (Menerva) to Canaan [part of the New Lebanon community], where she could be more directly under her Mother's government." ${ }^{19}$ Such concessions point to a two-tiered system of rules; one was the official, highly structured code of conduct as recorded in the Millennial Laws, the other was a loosely structured set of rules enforced by the family elders and strengthened or relaxed depending upon the behavior of members and the needs of the family as a whole. Even the laws themselves state that "those rules and regulations, relative to health, economy, and such as are the necessary attendants of local circumstances, in the social connection of society, are subject to such modifications, amendments, or repeals, as circumstances require." ${ }^{00}$ Each community and family within it had the freedom to determine standards on their own, as long as they did not violate any basic codes of Shakerism such as celibacy.

Built-in furniture in the dwellings also shaped the way Shakers used and perceived their domestic space. In the past, scholars have noted that the Shakers' widespread use of built-ins derived from their love of sparseness and their desire to save space. Built-in furniture also provided another method of controlling behavior and asserting order within dwelling houses.

The Shakers were not the first to use such furniture, but they incorporated it into their structures in many innovative ways. Cupboards and shelves were ubiquitous features of eighteenth-century Anglo and Dutch architecture in America. Many homes of wealthy families erected between 1750 and 1800 in the Northeast had built-ins. Thomas Jefferson installed ingenious dumbwaiters in a fireplace mantle to move objects between floors at Monticello. In Cottage Residences (1842), Andrew Jackson Downing recommended the "rising cupboard," or dumbwaiter, especially if the kitchen was in the basement. ${ }^{61} \mathrm{He}$ also noted that closets were "absolutely necessary" for providing adequate storage. ${ }^{62}$

That the Shakers chose to incorporate so much furniture into the physical fabric of their houses attests to the desire on the part of the ministry and elders to imbue all aspects of the house with order. Both communal and more private spaces had built-ins, as can be seen in the photographs of the meeting room in the brick dwelling in Hancock and a retiring room in the Great Stone Dwelling in Enfield (Figures 19, 20). Every large Shaker dwelling house had an attic filled with built-in cabinets and/or shelves to store goods accumulated as a result of the Shakers' growing population and wealth (Figure 21). The Shakers used a system of numbers and letters to ensure that each item would be stored in its proper place. ${ }^{63}$ In The Poetics of Space, the French philosopher Gaston Bachelard discussed the use of drawers, chests, and wardrobes as metaphors for classification and order. ${ }^{64}$ As an example, he referred to Henri Bosco's Monsieur Carre-Benoit à la campagne. Carre-Benoit has a singular affection for his solid oak filing cabinet because its forty-eight drawers allow him to sort thousands of objects. ${ }^{65}$ Although there is no evidence that the Shakers professed such emotions for their furniture, the built-in drawers and cupboards allowed the dwelling houses to func- 


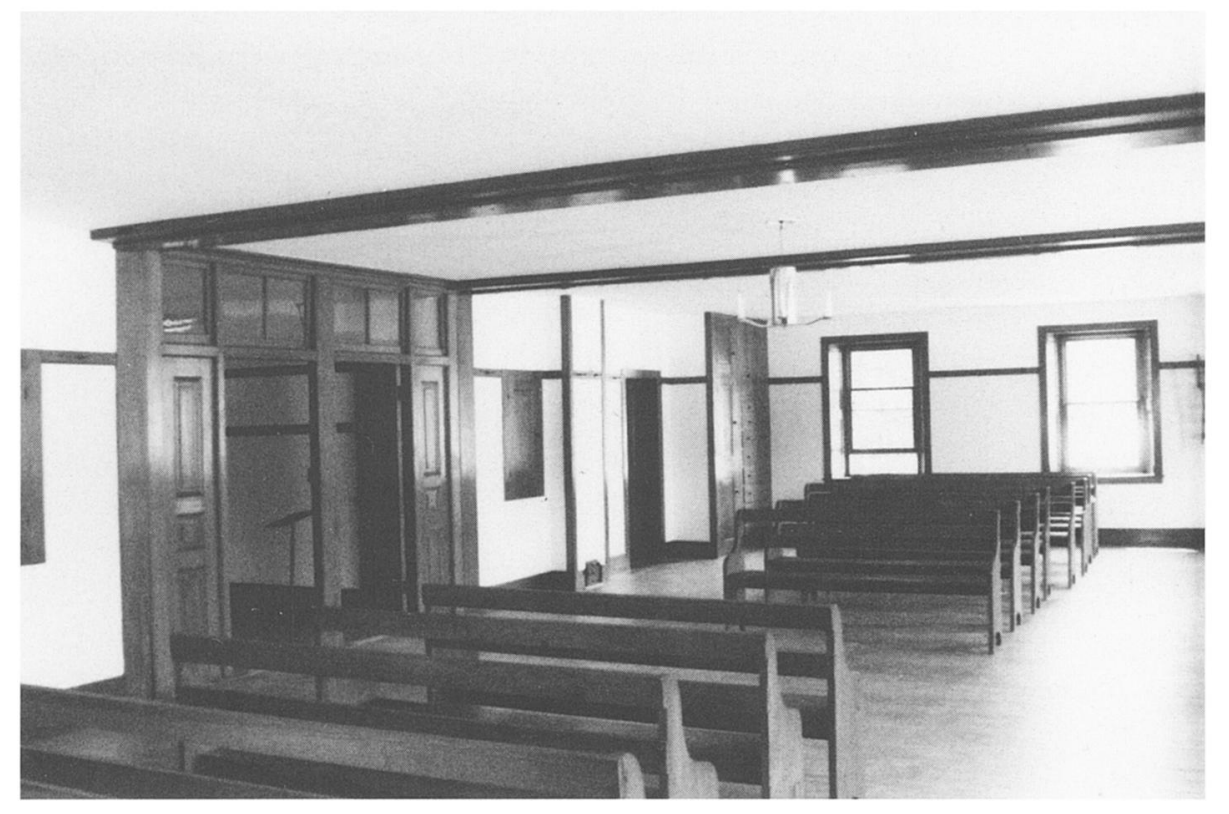

Figure 19 Meeting room, Brick Dwelling House, Church Family, Hancock, 1830

Figure 20 Built-in drawers and cabinets, retiring room, Great Stone Dwelling House, Enfield

Figure 21 Built-in drawers and cabinets, attic, Brick Dwelling House, Church Family, Hancock. Photograph by Elmer R. Pearson, 1970, Historic American Buildings Survey
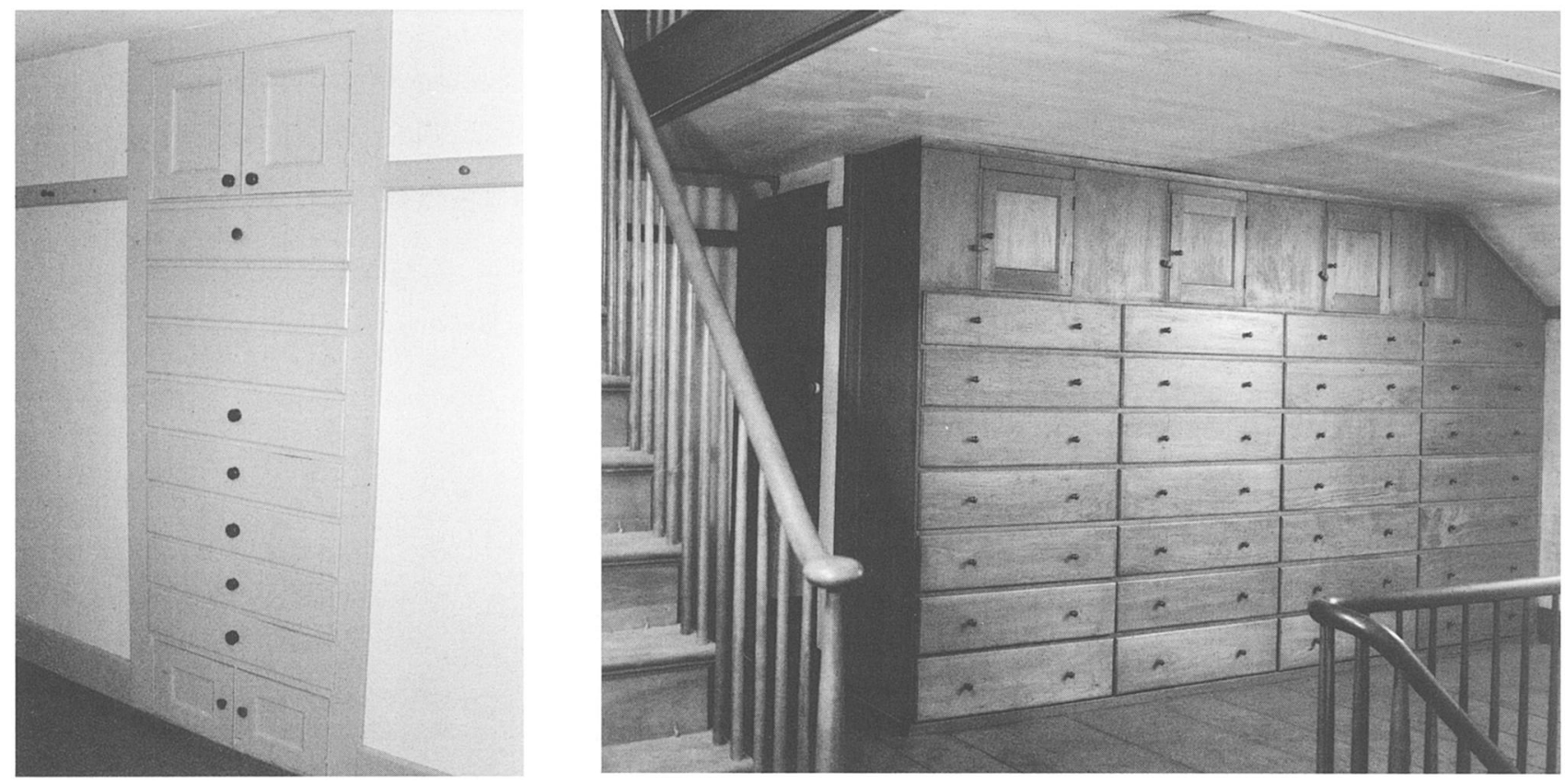

tion as large filing cabinets. The various retiring rooms organized the inhabitants within by age, sex, occupation, and religious conviction, while the built-ins permitted the elders to keep track of the clothing and other material possessions of those who lived in the houses. Thus the Shakers literally built order into the arrangement of interior space.

As a reflection of control, the desire for cleanliness always pervaded the Shaker environment, but its impact varied in degrees from time to time. During Mother Ann's Work, the central ministry instituted the "sweeping gift," which became an annual ritual in all Shaker communities for the next eight years. ${ }^{66}$ Beginning in December 1841 in New Lebanon: "The Elder brethren \& the 4 Instruments [members through whom spirits spoke] aforesaid, continue their singing \& marching from building through the 1st Order. The Sisters, both Elderesses \& Instruments go in company with the Brethren in the M.[eeting] house, dwelling houses Office wash-house \& such buildings are improved by both sexes, but in other buildings they go seperately $[s i c]$. They have followed this work every day this 
week, thus far, sweeping \& cleaning the buildings. The $2 \mathrm{~d}$ Order are cleaning their habitations likewise." ${ }^{67}$

The Shakers, equating physical cleanliness with spiritual purity, saw all dirt as being evil. Such a view was not unusual for the time. Mainstream Americans became increasingly concerned with household sanitation as well. In her prescriptive book on domestic architecture, Catharine Beecher recommended numerous ways to allow in natural light and maintain cleanliness and good ventilation in the home. She suggested that every chamber have a chimney and an opening above the door. ${ }^{68}$ Good air circulation also concerned the Shakers, and they took steps in the mid-nineteenth century to achieve it in their houses. In January 1855, carpenters cut windows over all the doors in the New Lebanon North Family's main dwelling house so air could circulate from the halls into the retiring rooms. ${ }^{69}$ Dwellings in Pleasant Hill and South Union, Kentucky, were built with arched transoms to allow more light into interior spaces (see Figure 9). These windows were also common in large institutional structures such as hospitals, where light and proper air circulation were considered vital to the good health of the patients.

\section{Shaker Reform in a Larger Context}

The Shakers' desire to improve its members and ultimately reform society paralleled goals of mainstream Americans. While the Shakers busily overhauled their old dwellings and built new ones, private groups and state governments began constructing institutions meant to incarcerate and reform society's misfits - the criminal, the insane, and the poor.

The reasons for this new treatment of societal outcasts are not entirely clear, although scholars have suggested various settings that encouraged the institutionalization of those who were deemed deviant. I argue that evangelicalism arising from the Second Great Awakening in the early nineteenth century played a role in furthering the cause of reform based on good intentions, mixed with a consolidation of power among certain reform groups and, in the case of publicly run institutions, with the state. In his studies of the rise of the penitentiary and of the asylum, Discipline and Punish and Madness and Civilization, respectively, Michel Foucault suggested that Enlightenment thought encouraged society to bring deviants under the control of reason. ${ }^{70}$ Foucault took a critical view of prison and asylum reform, stating that such institutions reflected modern industrial society in which fear and conformity were used to subdue and discipline their inmates. Although his work opened new avenues of scholarship on institutions, he did not apply his theories to actual buildings or communities.
Rothman also takes a negative view of the reform of prisons and asylums. In The Discovery of the Asylum: Social Order and Disorder in the New Republic, he sets the establishment of these institutions within the context of the Jacksonian age and relates the birth of the asylum to society's desire to incarcerate misfits rather than maintain them within the community ${ }^{71}$ Rothman suggests that as the nineteenth century progressed, state institutions in particular became holding pens for the poor, the insane, and immigrants from eastern and southern Europe, and argues that the strong impulse toward discipline and incarceration was a reaction to social disorder of the period. Other historians have studied specific types of institutions and their architecture, placing the rise of prisons, asylums, and hospitals within the context of social history, religious history, and women's studies. ${ }^{72}$

Although the Quakers and Shakers had established themselves before the Second Great Awakening began, both groups used the spirit of reform emanating from this period to further their own ideas of reform and to demonstrate the truth of their beliefs. In addition, the two groups used architecture to reform individuals. The Quakers played a leading role in introducing prison reform and moral treatment of the insane to the United States. The Shakers chose to build new villages with specific forms of architecture adapted to their ideas. Although the Shakers were not an offshoot of the Quakers, they shared many views with them, having been part of the English tradition of religious dissent. Both groups had experienced persecution and imprisonment in England and America; both adhered to pacifism, a tenet that led many members to be imprisoned during the Revolution, the War of 1812, and the Civil War, until the United States government granted them exemption. This history of dissent loomed large in the Quaker and Shaker mentalities. Most important, both groups believed in an inner or "Christ spirit" that dwelled within every person, making it possible for humans to perfect themselves. The two sects, however, worked for reform in different ways. Whereas the Shakers separated themselves from the world and sought social change within their own communities using celibacy and other control mechanisms, the Quakers, well established and part of the outside world, sought reform in mainstream society through charitable organizations and institutions. The latter group initially had the most influence in Philadelphia and New York City, where it led movements to improve the conditions of criminals and the mentally ill.

Until the late 1700s, Americans considered crime and insanity localized difficulties rather than critical, sweeping social problems. A mostly rural population with small towns and few cities had a limited number of institutions to deal 
with social deviants. ${ }^{73}$ Punishment for crimes included fines, whipping, placement in the stocks, or death. Towns imprisoned persons awaiting trial, but did not see incarceration as the final punishment. ${ }^{74}$ If such measures did not reform the criminal, the community usually ejected him or her. Local authorities treated the poor and insane differently. Usually families or neighbors cared for these groups. Although a handful of almshouses existed in urban areas like Boston and New York, such institutions were not large enough to house all the disabled, poor, and insane in a region. In the 1600 s, some colonies, including Massachusetts, Connecticut, New York, and Rhode Island, passed laws requiring communities to care for the mentally ill without families. ${ }^{75}$

As did the Shakers' earliest dwelling houses, eighteenth-century jails followed the "family model for organizing an institution" and consequently resembled a large house. ${ }^{76}$ Inmates in such prisons were not confined to a cell, did not have to wear a uniform, and were not restrained in any way. No systems of supervision existed. The eighteenth-century jail was not meant to reform.

The new models that developed in early-nineteenthcentury America seem to have been drawn from several sources, leading to some debate as to whether American reform institutions were based on European models or homegrown. Rothman argues that although Americans rejected eighteenth-century mistreatment of the incarcerated, as did Europeans, institutions of reform in the United States responded to uniquely American social problems. ${ }^{77}$ Nevertheless, it is clear that the writings of European reformers, namely the Milanese jurist Cesare Beccaria's On Crimes and Punishments (1764) and the Englishman John Howard's The State of the Prisons in England and Wales (1777), drew the attention of both Europeans and Americans to the need for improving the treatment of the criminal and the insane through laws and the construction of more humane institutions. ${ }^{78}$ Other historians have argued that European theories and buildings influenced the construction of new institutions in the United States. Norman Johnston's work on Eastern State Penitentiary in Philadelphia (1829) shows that the "so-called radial, or hub-andspoke" design of John Haviland, newly arrived from Great Britain in 1821, reflected the plan of many county prisons being built at the time throughout the British isles. ${ }^{79}$ In her examination of the Massachusetts State Prison at Charlestown, designed by Charles Bulfinch and opened in 1805, Elaine Jackson-Retondo states that the influence of the works of Beccaria and Howard "could be seen in the reform rhetoric, prison discipline, and siting of the Massachusetts State Prison at Charlestown as well as other nineteenth-century penal institutions." ${ }^{80}$ Solitary confinement, a system used extensively in Pennsylvania in 1800s, was first envisioned by an Englishman, Jonas Hanway, in a 1776 plan of a penitentiary. ${ }^{81}$

The role of Jeremy Bentham and his Panopticon is more difficult to ascertain. Though Rothman argues that Bentham had little impact because his writings were not well known in America, other historians have credited Bentham with greater influence. According to Johnston, citing Blake McKelvey's work, some reformers, especially Thomas Eddy, a Quaker merchant involved with the planning of New York state's new penitentiary in Auburn, argued for the incorporation of separate night cells there, referring to the work of Howard and Bentham. ${ }^{82}$ Johnston also observes that the two large prisons erected with circular or semicircular plans in the United States, the Virginia Penitentiary in Richmond (1800), by Benjamin Latrobe, and the first Western Penitentiary in Pittsburgh (1826), by William Strickland, reflected elements of Bentham's Panopticon and many small county prisons erected in Ireland and England prior to $1820 .{ }^{83}$ Although no prison was constructed based on Bentham's plan, the approaches Bentham expressed in Panopticon; or, the Inspection-House (1791) were ideas embodied in later prisons and asylums built in the United States. Panopticon was one of the first publications to propose an entire system for supervising "persons of any description." 44 Bentham's plan, based on a round structure with a central watchtower, worked on the premise that inmates would behave correctly as long as they believed they were being constantly observed. The plan of the Panopticon (Figure 22) shows a watchtower surrounded by levels of cells, all within view of the guard hidden inside the central viewing chamber, or lodge. Robin Evans notes that one of the most extraordinary features of the Panopticon was that it "brought the prison into the realm of utopia." ${ }^{85}$ It provided a model environment that could be replicated in isolation from the rest of the world allowing reason to take control. This perception of the Panopticon as a utopia was appealing to a new nation that was experimenting with a number of models for improving society.

Bentham's work sets out specifications for the Panopticon, covering everything from the size of the units and passageways to the lighting of the inmates' cells so that convicts could be viewed both day and night. He suggested incorporating running water and individual toilets into each cell to enforce solitary confinement within the structure. Bentham's idea of supervision encompassed not only the prisoners themselves, but also the inspectors, who would be watched by the superintendents, who in turn would be observed by the visiting public. In this way, the entire structure of the building would be pervaded by an atmosphere of 


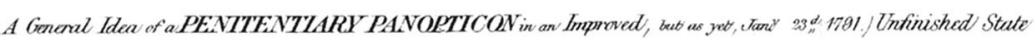
See Pestscript References to Pllan. Elesation \& Sedtion, being Plate referred to as $N^{\circ} 2$



Figure 22 "A General Idea of a Penitentiary Panopticon in an Improved, but as yet, Jany 23d 1791.) Unfinished State." From The Works of Jeremy Bentham published under the superintendence of his executor John Bowring, vol. 4 (London, 1843), insert before p. 37 unyielding watchfulness that would keep everyone under control. Bentham realized that constant supervision would be impossible, so he provided means to have the inmates believe as much. ${ }^{86}$ While prisoners could always be seen in their cells from the watchtower, the lodge itself was screened so that they could not tell when someone in it was watching them.

Bentham proposed the use of forced labor to subdue inmates and to make the jail self-supporting. He believed that for the most efficiency, the trade should be chosen by the inmates themselves, based on what each one was most adept at or particularly enjoyed. As a form of incentive, the most productive inmates would be rewarded with meat, beer, or even small earnings.

Although Bentham's plan began with the premise that prisoners would be contained in individual cells, later he suggested that his Panopticon would operate even better if each unit contained two to four people. Through an economy of construction, the same cell could serve many functions, including sleeping, eating, working, worship, and punishment. ${ }^{87}$ Roommates could work together more efficiently and therefore be more productive. Bentham also considered housing both men and women in the same building. ${ }^{88}$ Such accommodations could be possible only if the sexes were in opposite sides of the edifice and hidden from each other's view by a large drape hung across the center of the building. Male inspectors would be assigned to view the men, and female inspectors would watch the women.

Bentham saw far-reaching applications for his Panopticon, arguing that it could be employed by prisons, factories, asylums, hospitals, and schools. ${ }^{89}$ Not only would the inmates be subdued by believing they were under constant supervision, but the superintendent or warden of the institution could also easily classify inmates. In an insane asylum, violent patients would be separated from calm ones. In a school, bright students would be set apart from slower ones. ${ }^{90}$ Many aspects of Bentham's Panopticon are common to institutions of reform. Rothman outlines their major characteristics: 1) incarceration as the primary means of punishment and treatment; 2) a unity of design and structure among all types of institutions; 3 ) the isolation of nineteenth-century institutions conveyed through solid walls and policies that separated inmate from outsider; 4) the division of daily routines into blocks of time maintained by the ringing of bells; 5) the emphasis on work and solitude; 6) the ability to maintain order in the early years that eventually gave way by the mid-nineteenth century to disorder; and 7) with a few exceptions, the emphasis on the treatment 


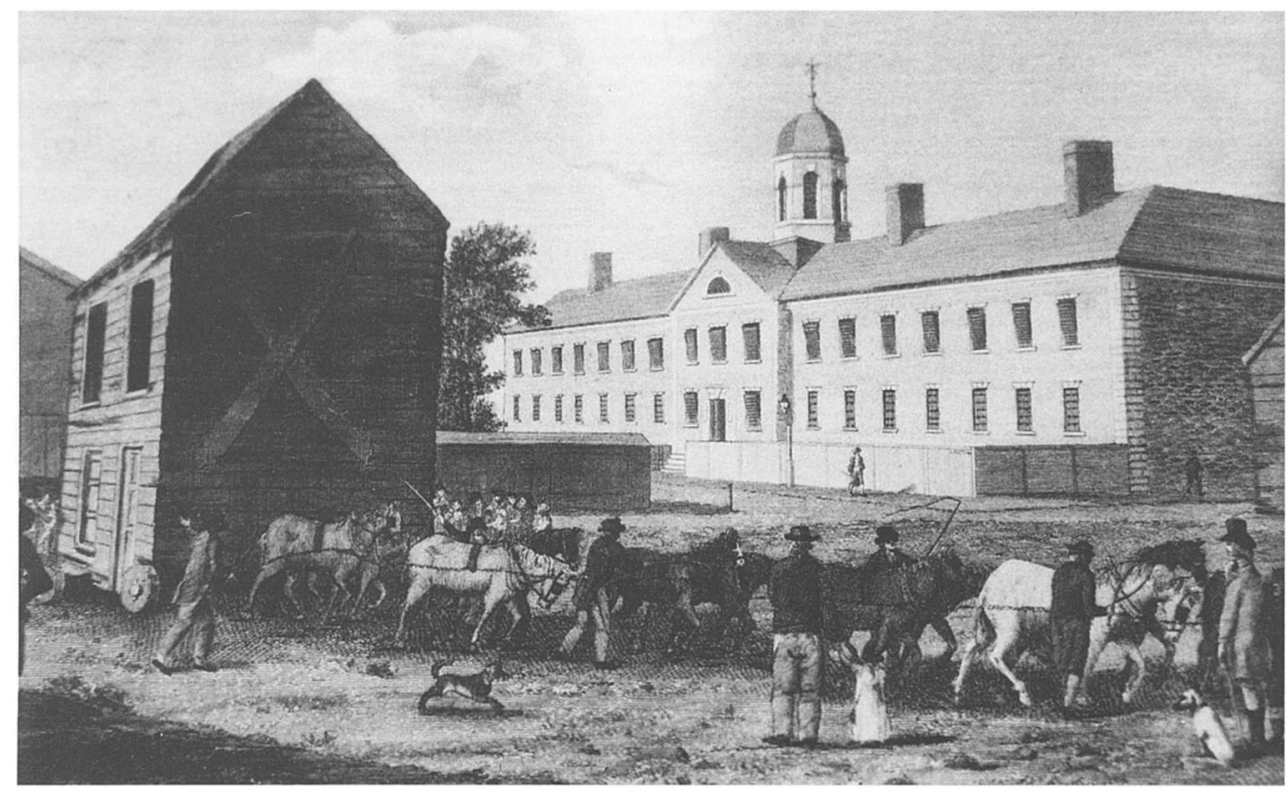

Figure 23 Walnut Street Jail, Philadelphia. Engraving from William Birch and Son, The City of Philadelphia in the state of Pennsylvania, North America; as it appeared in the year 1800, consisting of twenty-eight plates (Philadelphia, 1800), unpag.

Figure 24 Charles Bulfinch, "View of the Principal Front of a Building Proposed for a

Prison or Penitentiary House," Charlestown, Massachusetts, 1802

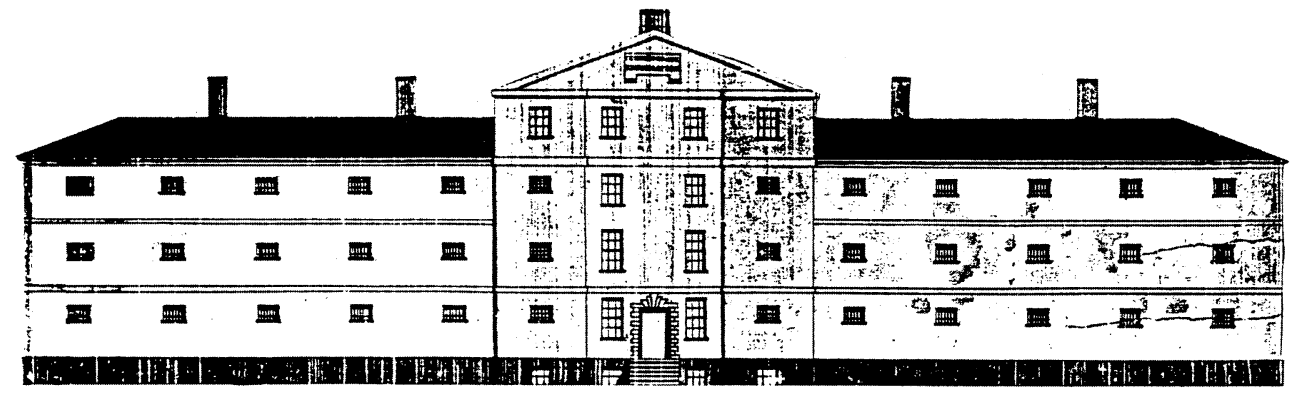

of the lower classes. ${ }^{91}$ All but points 1 and 7 can be applied to Shaker architecture as well. Although there is no evidence that the Shakers knew of Bentham's Panopticon, the similarity of his proposals to practices that the Shakers instituted in their dwellings indicates that his ideas as transferred to American reform institutions may have had some influence on the Shakers' architecture.

Prison reform began in earnest in Philadelphia with the formation in 1787 of the Philadelphia Society for Alleviating the Miseries of Public Prisons (later called the Pennsylvania Prison Society), the first organization of its kind in America or Europe. It counted among its members leading men of the city, including Dr. Benjamin Rush and Roberts Vaux, a Quaker penal reformer. One of their first projects dealt with the Walnut Street Jail, originally constructed in 1773 , opened in 1776, and made a state penitentiary in 1790 (Figure 23). ${ }^{92}$ Based on legislation promoted by the prison society, the state erected a small cell block within the prison enclosure to provide solitary confinement for the worst offenders, who in an earlier age would have been sentenced to death. ${ }^{93}$ In the same year, the Pennsylvania state legislature passed a series of new penal laws that abolished punishment by death, mutilation, or the whip. ${ }^{94}$ The prison society believed that convicted criminals could be reformed through a period of incarceration, during which the inmate would reflect on his sins through religious instruction and hard physical labor.

In the $1800 \mathrm{~s}$, prisons were located in small towns or on the outskirts of cities to isolate the prisoners from corrupting urban influences. Rural settings were thought to be conducive to reform. The state of Massachusetts constructed such a prison in Charlestown in 1804-5. In the 1802 plans for the penitentiary (Figure 24), architect Bulfinch proposed an elevation that closely resembles the tripartite design of the Walnut Street Jail. This type of structure, with a central block for the kitchen, keepers' apartments, hospital, and common spaces, and two wings for the prisoners' cells and workshops, organized space into clearly defined areas (Figure 25). (It also became a standard layout for insane asylums, hospitals, orphanages, and other institu- 

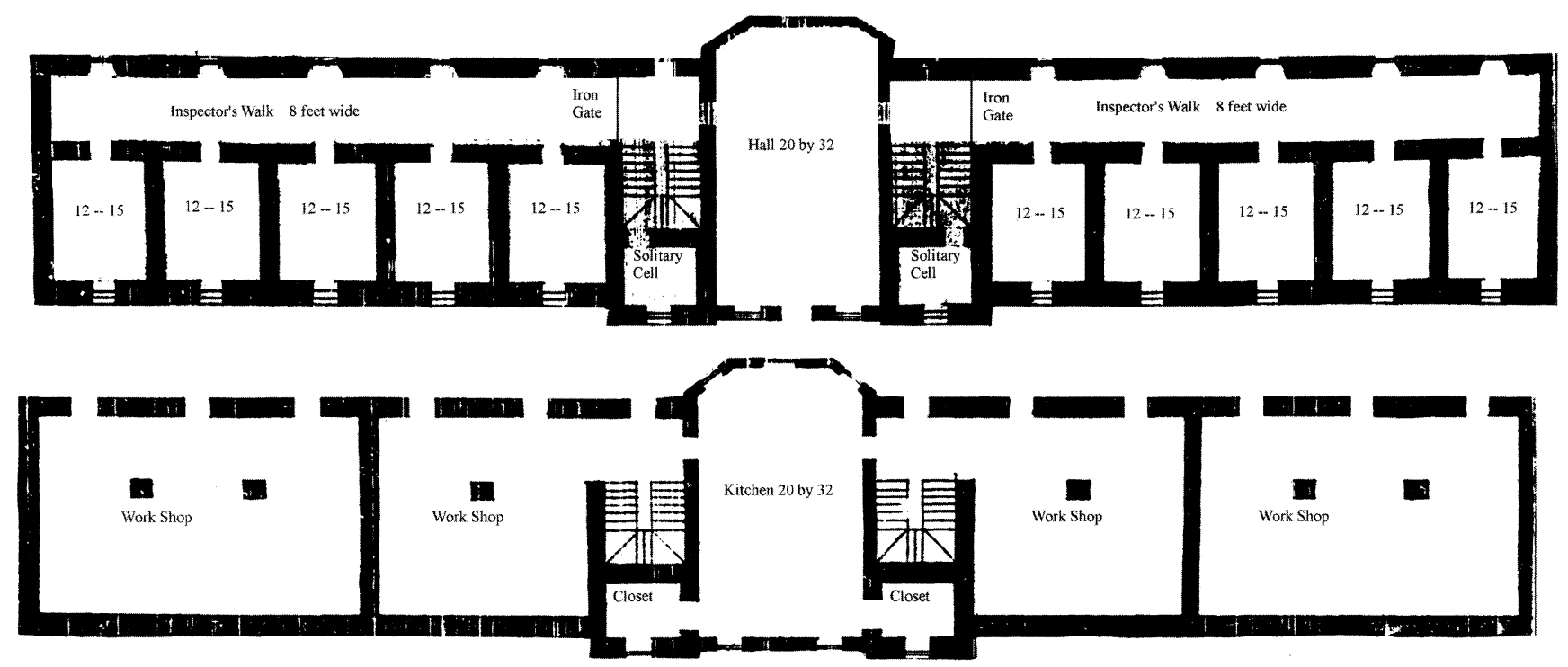

Figure 25 Bulfinch, first-floor (top) and basement- (bottom) plans, State Prison, Charlestown, 1802

tional buildings.) Bulfinch initially laid out only one row of cells on each floor so that light could filter in through the barred windows from both sides of the wing. As built, however, the prison had double-loaded wings of units, reducing light and air circulation. The building was designed to allow group labor during the day and solitary confinement at night, a system later refined by and associated with the Auburn State Prison in New York. ${ }^{95}$ Extra-thick walls around the cells, workshops, and other areas where the prisoners were held provided security against escape. Despite the precautionary measures and the need to create a secure structure, these early prisons were still perceived in a domestic sense. They were called jail houses or penitentiary houses and were considered temporary devices to help the convict reenter society.

The situation changed in the next decade, when New York established the congregate system at the state prison in Auburn in 1816. Similar to the arrangements at the Walnut Street Prison and at Charlestown, the congregate model allowed inmates to eat and work together, but isolated them at night. However, the fortresslike appearance of the Auburn prison reflected society's belief that incarceration could permanently reform individuals. Whereas the early Philadelphia, New York, and Massachusetts prisons still resembled large houses, the Auburn prison's crenellated roofline and monotonous repetitive walls expressed the strength and order required to mold inmates into respectable citizens (Figure 26).

The Eastern State Penitentiary (Figure 27), a similarly imposing structure, kept prisoners in solitary confinement around the clock, sleeping, eating, and working in their individual cells with virtually no human contact. The architect, Haviland, noted that it followed Bentham's system but was not a true Panopticon (Figure 28). Although the structure's wings radiate from a central axis, they stand only one story tall, with a few wings raised to two stories to accommodate more prisoners. In addition, the cells would have blocked each prisoner's exterior yard from the view of guards in the central tower. ${ }^{96}$ Like the Panopticon, however, each cell at Eastern State was furnished with running water and a primitive toilet to ensure absolute isolation of each inmate. Many reformers lauded the "advances" made at Pennsylvania. ${ }^{97}$

In 1831, Alexis de Tocqueville and Gustave de Beaumont traveled throughout the Northeast to examine American penitentiaries for the French government. They were not impressed with the system of solitary confinement; rather, they believed that absolute seclusion harmed the inmates' health. Indeed, New York State instituted such confinement at Auburn in 1821, but ended it two years later after several prisoners went mad from the isolation. With a sense of irony, they noted that "whilst society in the United States gives the example of the most extended liberty, the prisons of the same country offer the spectacle of the most complete despotism." ${ }^{98}$ According to Tocqueville and Beaumont, the Eastern State Penitentiary was built for $\$ 432,000$, bringing the price of each cell to $\$ 1,624$. The massive outside wall surrounding the prison structures cost $\$ 200,000$. In contrast, the state prison in Wethersfield, Connecticut, was constructed in 1827 following the Auburn plan for a 


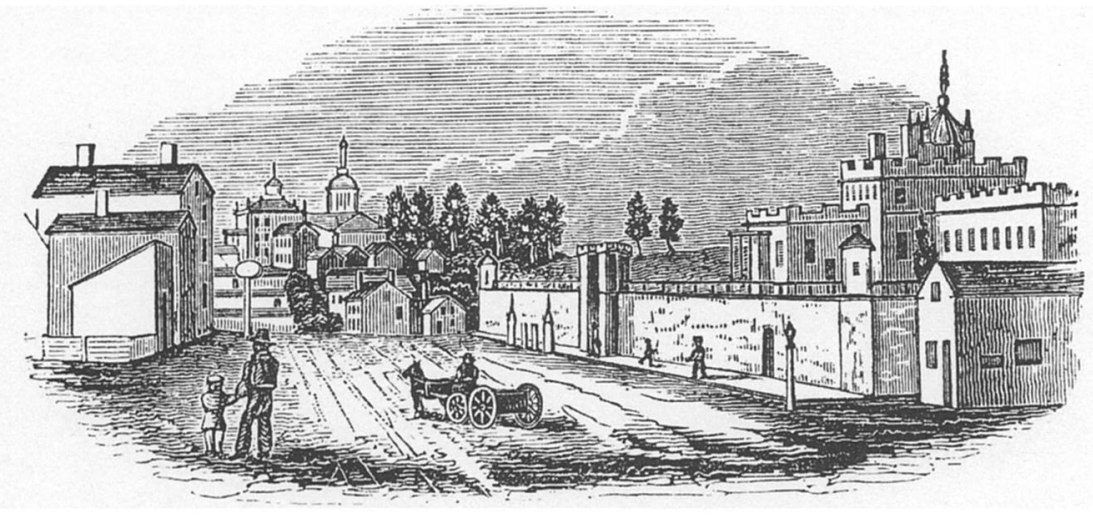

Figure 26 "State Prison at Auburn," 1816

Etching from Barber, Historical Collections of the State of New York, 61

Figure 27 John Haviland, Eastern State Penitentiary, Philadelphia, 1829. Engraving by C. C. Childs, Philadelphia, 1829

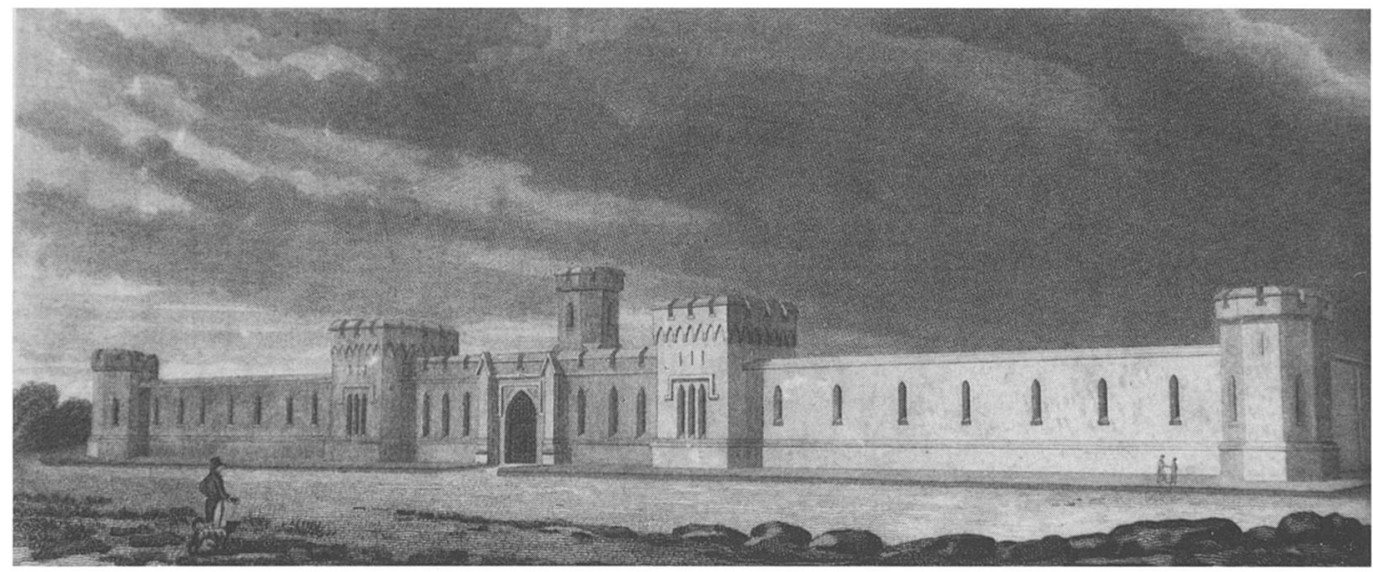

total of $\$ 35,000$, with each cell costing $\$ 150.86 . .^{99}$ The two French visitors regarded the Philadelphia prison as absurdly expensive, especially because the inmates were continuously confined to their own cells and yards. They also noted that the amount of space afforded to every individual was generous; each cell was eight by twelve feet, with sixteen-foot ceilings. Prisoners' yards measured eight by twenty feet. ${ }^{100}$ Tocqueville and Beaumont believed the huge walls, Gothic towers, and wide iron gates to be unnecessary decoration, though they admitted that Haviland effectively made the prison look like a medieval fortress, thus conveying to passersby the solemnity of its purpose. ${ }^{101}$

Indeed, Haviland intended the prison to be the most advanced of its kind in the treatment and reformation of criminals. The symmetrical plan imposed an order over its inhabitants that was intended to pervade their very psyches. However, as is clear from the figures quoted above, such progress required the expenditure of great sums of money to provide a clean and somewhat comfortable environment. ${ }^{102}$ The prison had facilities to fill every practical need, including apartments for the warden and inspector, a hospital, an apothecary's office, and gardens to provide food for the inmates and staff.

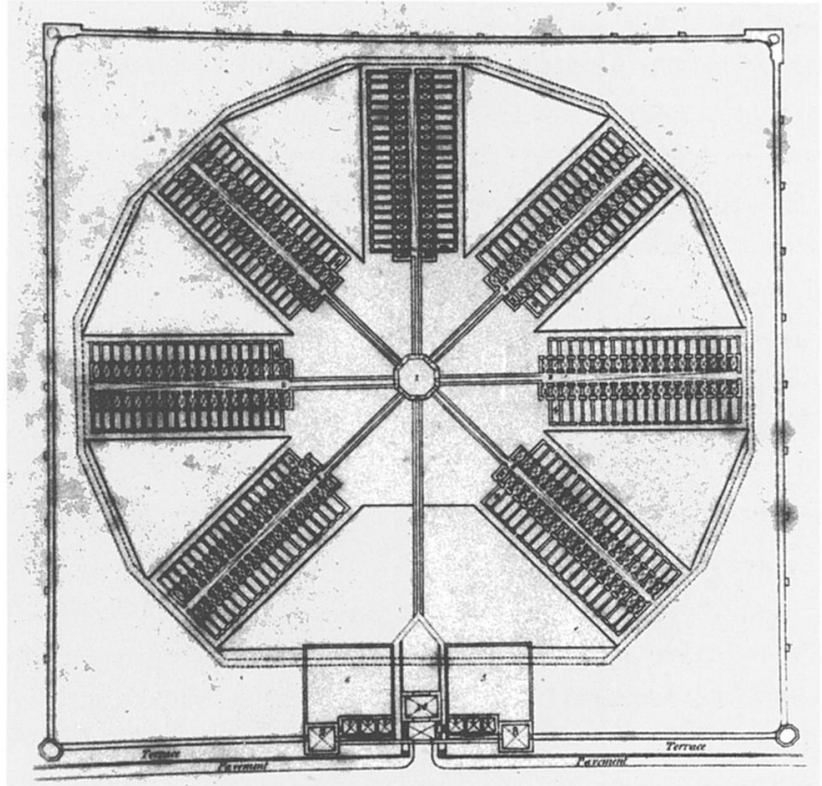

Figure 28 Haviland, plan, Eastern State Penitentiary. Engraving by C. C. Childs, n.d. 
Auburn and Eastern State became the models for the two systems of incarceration that existed in the United States during the nineteenth century. The former was based on congregate work while the latter was centered around complete solitary confinement. Although the two plans differed structurally, they shared many rules and goals, including absolute silence, which prevented prisoners from communicating with one another and thus lessened the chance of riots or escapes. Reformers believed that supervision via a central watchtower, as at Eastern State, or through wardens patrolling the halls ensured strict adherence to the rules. Although the idea of constant supervision was as important as the fact in keeping prisoners submissive, the Pennsylvania system also relied heavily on isolation to control them. Wardens used set schedules and prison uniforms to maintain conformity; rules were meant to lessen the sense of individuality and make inmates more responsive to orders. Reformers also hoped that labor and religious education would lead the prisoner to strive for redemption. Few reformers in the early 1800 s paid much attention to the plight of female convicts, who suffered extreme mistreatment as conditions for male prisoners improved. ${ }^{103}$

Despite the attention given to the Eastern State Penitentiary, few states drew on Haviland's design, mainly because it was expensive to construct: the cost of each cell was roughly ten times that of one built after the Auburn plan. Nevertheless, variations on Haviland's prison occasionally appeared, most notably in the Civil War-era Hammond General Hospital at the United States General Depot for Prisoners of War, Point Lookout, Maryland. Many more penitentiaries followed the Auburn plan, with its huge walls punctured by monotonously repeating windows. The repetitious façade reflected the rows of cell blocks within. Among the best known of these prisons are the Massachusetts State Prison in Charlestown, which adopted the Auburn plan in 1826, the Connecticut State Penitentiary in Wethersfield, and Sing-Sing Prison in Ossining, New York (1825).

The prison reform movement had widespread influence. Other benevolent societies such as the Boston Prison Discipline Society (1825) were founded to investigate local jails. From 1820 to 1850 , Georgia, Kentucky, Maryland, New Hampshire, Ohio, and Vermont had built prisons. Most adopted the Auburn system because they believed it to be cheaper to build and run, to provide better vocational training, and to produce more money for the state than the Pennsylvania model. Coming out of the spirit of reform that pervaded the era of the Second Great Awakening, new penal methods applied more humane forms of incarceration while being guided by the practical aspects of running state institutions.
Although there is no evidence to suggest that the Shakers were directly influenced by prison reform, the sect did have knowledge of reform movements. By the 1830s, the Shakers were allowed to read popular magazines, including Scientific American, Century, American Magazine of Useful and Entertaining Knowledge, and Penny Magazine, where they may have learned about prisons and insane asylums. ${ }^{104} \mathrm{In}$ addition, many Shaker villages were located near urban centers and reform institutions; New Lebanon was only two hundred miles from Auburn and just a hundred miles up the Hudson River from Sing-Sing. Trustees conducting business for the Shakers would likely have passed these prisons on their trading routes. Furthermore, Shaker communities incorporated the values of religion, work, and silence, which the Quakers introduced into prisons to induce moral improvement. The Shakers ate and worked in silence and according to strict schedules. They sought to enforce conformity through dress, behavior, and environment, which stripped members of their individual identity. The main difference between Shaker villages and prisons, of course, was that a Shaker was always free to abandon the community, a prison inmate was not.

That the Shakers knew about nineteenth-century prison reform, but viewed it with some trepidation, is difficult to prove. Despite the long, often detailed descriptions of cities, buildings, and the villages of other communal societies recorded by traveling Shakers, there is no record of a member even passing by a prison. One reason for this silence is a rule in the Millennial Laws under section XV, "Orders concerning going Abroad, and Intercourse with the World": "It is forbidden for Believers to go into Museums, Theatres, or to attend Caravans or shows, to gratify curiosity; and none should go on board of Steam Boats or Vessels, or into prisons or jails, unless duty requires." 105 The elders no doubt deemed these institutions off-limits to Shakers because they were corrupt influences-museums and theaters of the mind, prisons of morals. Nevertheless, given the travels of elders and trustees and the reading material available to Shakers in the early 1800 s, it seems likely that the sect was aware of reform movements in American society.

Other institutions in early-nineteenth-century America shared the same goals and intellectual heritage as the Shakers and prison reformers. The rise of the insane asylum reflected the hope that the mentally disabled could be cured by removing them from mainstream society and placing them in an environment designed to rehabilitate. As with the new prisons, the first advances in the treatment of the insane in America began in Philadelphia under the leadership of the Quakers. 




Figure 29 "Plan of the Principal Story of the State Lunatic Hospital," Worcester, Massachusetts. The central structure is located at the top center of the image. Lithograph by T. Moore, Boston, n.d

In 1751, a group of Philadelphia civic leaders, including Benjamin Franklin, established the Pennsylvania Hospital, the first in the American colonies, to provide public and private aid for the ill. One year later, the hospital initiated a policy of accepting the insane. ${ }^{106}$ This move reveals a shift in the perception of the mentally ill. By the 1700s, doctors considered insanity to be a disease located within the individual, not caused by supernatural powers. Although few doctors believed it was curable, hospital treatment provided the best hope for improvement. ${ }^{107}$ In 1773, the asylum at Williamsburg, later named the Virginia Eastern Asylum, opened. This institution was the first public hospital devoted only to the care of the mentally ill. ${ }^{108}$ Both institutions represented a change in society's expectations; communities were willing to accept more responsibility for treating the insane. Yet, efforts focused on support and maintenance rather than on developing humane methods for curing these patients.

By the first decades of the nineteenth century, the Quakers had begun to establish retreats based on the humanitarian treatment of the insane. In the 1790s, independently of each another, Philippe Pinel, of the Bicêtre and Salpêtrière hospitals in Paris, and William Tuke, a Quaker in York, England, implemented moral treatment of the mentally ill based on "minimal physical correction, incentives to self-control, and firm paternal direction." 109 Influenced by the 1813 Philadelphia edition of Samuel Tuke's Description of the Retreat, an Institution near York, for Insane Persons of the Society of Friends, the Quakers opened the Friends' Asylum in Frankford, just outside of Philadelphia, in $1817 . .^{110}$ In addition to removing the insane from the city, the Quakers segregated the patients by sex and behavior. The most ill were isolated from the rest of the group as a means of limiting negative influences on those who had the best chance of recovery. The Friends' Asylum also instituted a domestic environment by housing the superintendent and his family in the same building with the patients. This arrangement allowed constant monitoring of the staff and patients while downplaying the feeling of strict supervision.

The apparent success of moral treatment in private asylums such as the Friends' led to a public outcry for state institutions. Leland Bell suggested two main reasons for the rise of what he called the Great Reform Era, which lasted from 1830 to 1850 . First, the effectiveness of moral treatment in private asylums encouraged the belief that insanity was curable; and second, the inadequate and limited housing for the insane aroused a reform impulse to persuade the government to build state institutions. ${ }^{111}$ To these explanations we can add the rise of benevolent movements coming out of the Second Great Awakening. State governments established numerous asylums in the following twenty years throughout the Northeast: the McLean Asylum (1818), affiliated with Massachusetts General Hospital, Boston; the Bloomingdale Asylum (1821), affiliated with New York Hospital, New York City; and the Hartford Retreat in Connecticut (1824). In 1833, the Worcester State Lunatic Hospital, Massachusetts, established under Dr. Samuel B. Woodward, became the model for other state hospitals in its paternalistic supervision of patients.

The plan of the Worcester State Lunatic Hospital was typical of asylums (Figure 29). The central structure, marked by a two-and-a-half-story entrance porch, stood four and a half stories high on a raised basement. This section contained the superintendent's apartments, visitors' rooms, and sitting rooms, and anchored the opposing wings that held 


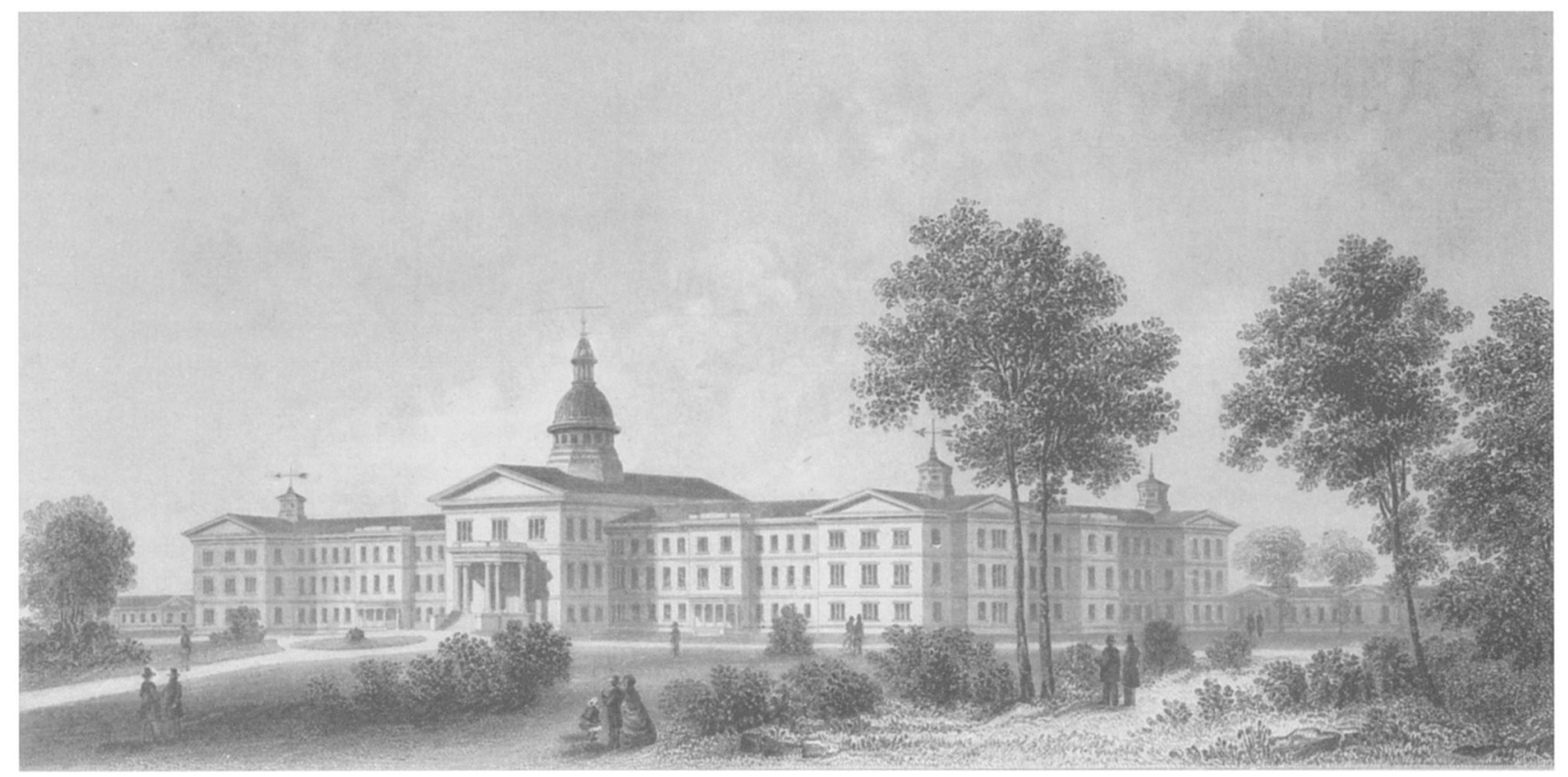

Figure 30 Male department, Pennsylvania Hospital for the Insane, Philadelphia, 1856-59. Engraving by W. E. Tucker, n.d.

the inhabitants. The superintendent's quarters on the fourth floor sat in the physical center of the hospital and gave him clear views of the asylum grounds as a reminder to staff and patients of the centralized control and supervision he held over the institution. Woodward became known as a practitioner of moral treatment, requiring his patients to engage in employment, such as farming and sewing; amusement, such as walking and riding; and religious worship. ${ }^{112}$ The imposing façade of the central section, though somewhat domestic in appearance, contrasted with the long, repetitious façades of the wings, which contained eight-by-tenfoot rooms for the patients. ${ }^{113}$ It is no accident that insane asylums resembled many state penitentiaries, since they shared common assumptions. Heads of both institutions considered the standard layout-a central core flanked by wings to classify inmates--vital to the maintenance of order and, consequently, the ability to reform. However, the bestknown and most influential asylum was the privately supported Pennsylvania Hospital for the Insane established in 1840 under Dr. Thomas Story Kirkbride.

Kirkbride, a Quaker, strongly advocated moral treatment, the use of compassion rather than chains to cure the insane. From 1832 to 1833 , he served as the resident physician at the Friends' Asylum. ${ }^{114}$ When offered the job as first superintendent of the Pennsylvania Hospital for the Insane, which was to open in 1841, he took it. Kirkbride's long tenure there, from 1840 to 1883 , allowed him to shape the institution into a self-contained society in which he could treat patients in the best manner he saw fit. According to Nancy Tomes, Kirkbride was typical of the first generation of asylum superintendents who, also being doctors, provided the medical rationale for asylum treatment. Thus, these men "legitimated the social forces impelling the insane out of the household and community." 15

Kirkbride had specific ideas for the physical structure of an insane asylum. ${ }^{116} \mathrm{He}$ called for the enlightened treatment of the insane in state-run hospitals and proposed a plan for a state hospital to accommodate 250 patients from all classes. His plan resembled those of the state institutions of New Jersey, Indiana, Illinois, Ohio, and Harrisburg, Pennsylvania. Kirkbride's site requirements paralleled those of early-nineteenth-century prisons and Shaker communities: the hospital should be set in the country, on tillable land, and near good transportation. The hospital itself should be isolated and its privacy fully secured, but views that "exhibit[ed] life in its active forms" were desirable. ${ }^{117}$ There should be from thirty to fifty acres of pleasure grounds immediately surrounding the buildings, but those of men and women should be distinct and enclosed from visitors. ${ }^{118}$

As for the buildings, Kirkbride believed a doctor knowledgeable in the treatment of the insane must approve them: "So different from ordinary buildings or other public structures are hospitals for the insane, that it is hardly possible for an architect, however skillful, or a board of 


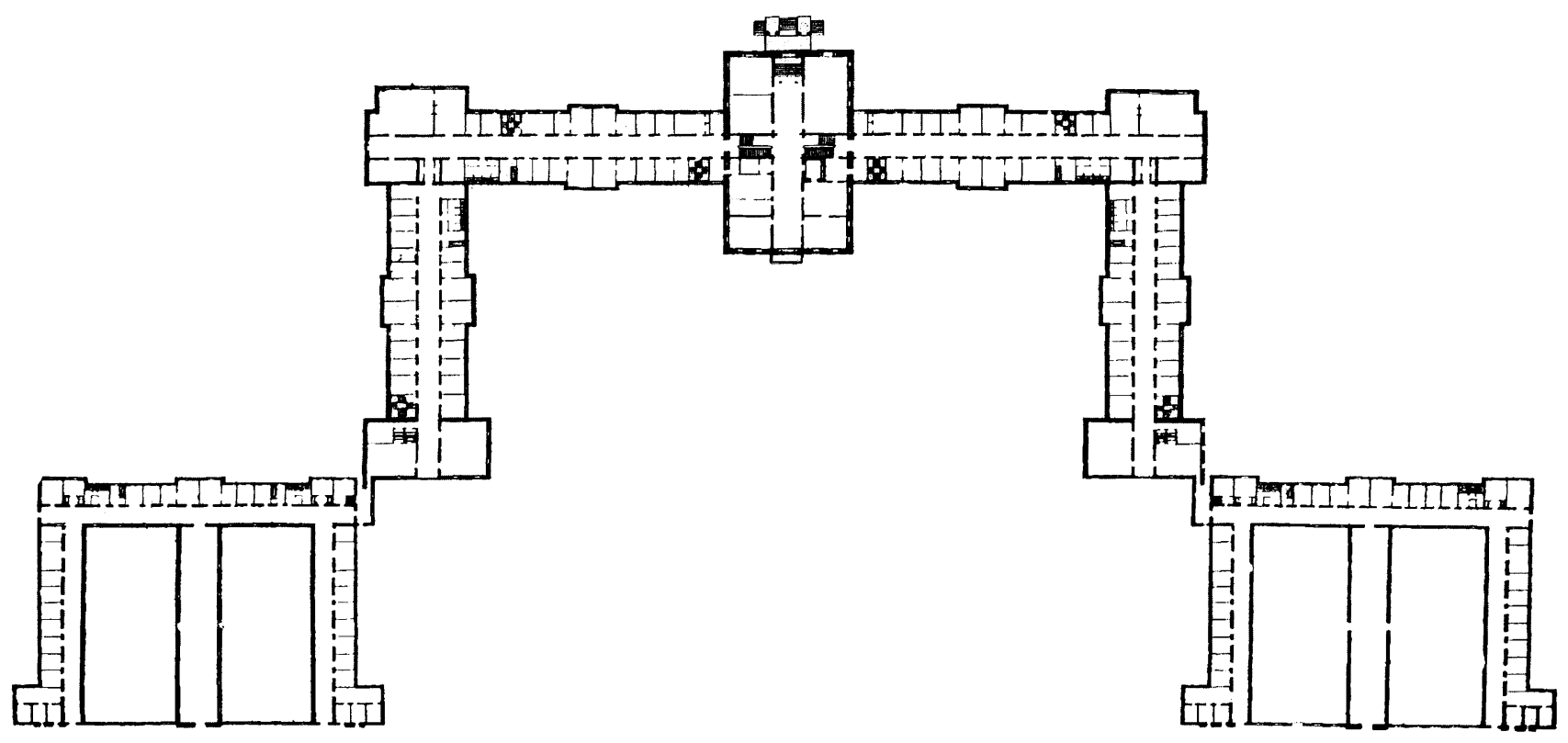

Figure 31 Male department, "Plan of the Pennsylvania Hospital for the Insane." From Thomas Story Kirkbride, On the Construction, Organization, and General Arrangements of Hospitals for the Insane, 2d ed. (Philadelphia, 1880), unpag.

commissioners, however intelligent ... to furnish such an institution with all the conveniences and arrangements indispensable for the proper care and treatment of its patients." Kirkbride argued that the interiors were most important and therefore should be planned first, and "the exterior so managed as not to spoil it in any of its details." 1 " The style of the building was not to be elaborate or costly, but in good taste, in order to resemble a country house rather than an institution. The means of security should be masked, this requirement stood in stark contrast to those of state prisons, which produced a fortresslike appearance.

Kirkbride's basic hospital building design was a threestory central structure with two flanking wings built of either stone or brick and topped with a copper, tin, or slate roof. Figure 30 shows the new asylum as built to Kirkbride's specifications in 1856-59. This structure became the male department, while the old building, erected prior to Kirkbride's arrival at the hospital, was designated the female department, effectively separating the sexes. The building followed a linear arrangement (Figure 31). The central block contained the offices, public spaces, kitchen, parlors, and library, while the wings held the patients' retiring rooms and work rooms. The entire space was important in presenting an atmosphere of domestic comfort. Perhaps Kirkbride had in mind the Worcester State Lunatic Hospital, where the center portion of the structure was "to be used in the same way as any ordinary dwelling-house." ${ }^{120}$ Each patient had a single room, while clothes rooms and bathrooms were shared among four patients. The long corridors and blocks of rooms allowed the location of patients according to mental condition, social class, age, and sex. As did Kirkbride, the Shakers believed classification of individuals was necessary to maintain order. They, however, segregated members according to religious conviction, age, and sex, as their aim was religious conversion and perfection.

Like the Shakers, Kirkbride believed that light and ventilation were most important for the health and comfort of the inhabitants. He specified room size: ceilings at least twelve feet high, corridors a minimum of twelve feet wide, parlors and large rooms twenty feet square, and patient rooms measuring nine by eleven feet. All windows were to have iron sashes so that patients could not throw themselves from upper stories. In patients' rooms, windows should be five feet six inches high by three feet wide and two per room. Gas lighting would illuminate the buildings at night. Although Kirkbride stated that the floors should be wood, he suggested having iron stairs to guard against fire. Bathrooms were to be nine by eleven feet and contain cast-iron tubs. The water closets contained a sink, urinals, and toilets, all cast-iron and well enameled. Such features were not common in the average home until the late 1800s. Kirkbride urged the incorporation of dumbwaiters to convey meals from the basement kitchen to the dining rooms. Other chores, such as washing, drying, and ironing, would 
be done in a building detached from the main structure so that patients would not be disturbed by the noise.

Kirkbride even specified the type and amount of furniture to be used in the main building so as to create an atmosphere similar to that of a private dwelling. Wellbehaved patients had a bedstead, a table and chair, a strip of carpet, and a small mirror in their rooms. However, none of the objects could have projections or sharp corners on which a patient might be injured. Kirkbride preferred iron over wood bedsteads, because they were heavier and thus harder to move around or damage. Excited patients were allowed no movable furniture. The table furniture of the dining rooms should be "neat and strong"; plain white tableware was desirable. ${ }^{121}$

His many specifications concerning the patients' living quarters are remarkably similar to the rules concerning dwellings laid out in the Millennial Laws. For example, the Shakers were permitted to have the following items in retiring rooms: "One rocking chair in a room is sufficient, except where the aged reside. One table, one or two stands, a lamp stand. ... One good looking glass." 122 Kirkbride, however, believed the mentally ill should have their own rooms to ensure their safety, whereas the Shaker elders used roommates as a supervisory measure. In addition, the Shakers restricted the amount of furniture a member could have in a retiring room. Built-in furniture prevented brothers and sisters from rearranging the layout of a room to better suit themselves. By controlling the very space inhabited by members or inmates, both the Shaker elders and Kirkbride wielded great power over their wards.

Kirkbride wished to establish a tightly supervised environment for the insane in much the same way the Shakers' attempted to create their own perfect society to improve their members. Both Kirkbride and the Shakers believed close interaction among men and women would upset the stability of the community. They felt that close sexual relationships might result in the transfer of allegiance from the community or leader to a lover. Both had strict hierarchical organizations, though along different lines. While the Shakers established a system of elders, Kirkbride re-created the social class structure of the outside world among his patients. He believed the complete separation of each class would provide stability for the patients, because it would mimic mainstream society. ${ }^{123}$ Naturally, such divisions also put Kirkbride at the apex of a social pyramid that provided the greatest benefits to those in the highest ranks of society. His denial of furniture or other objects for certain groups of patients had as much to do with preserving the social and economic status quo as it did with rewarding mental improvement.
Although striking similarities exist between Kirkbride's asylum and the Shaker dwelling houses, how can a common intellectual genealogy and reciprocal influences, if any, be determined? Both Kirkbride, a Quaker, and the Shakers came out of a long tradition of religious dissent and the Enlightenment belief that by controlling the environment, one could improve oneself and others. In addition, the Second Great Awakening in its focus on morality and individual improvement helped shape public opinion regarding reform. More specifically, Shaker journals reveal that the group had an interest in the plight of the insane. An article in an 1843 issue of New-Hampshire Magazine about the new state asylum in Concord lists, among the various contributors to the structure, the Shakers in Canterbury and Enfield, who collectively donated $\$ 500 .{ }^{124}$ The written description and an accompanying engraving of the asylum show it to be similar to those buildings on which Kirkbride based his 1854 plans (Figure 32). According to the article, inmates received religious education, attended services in the village, and performed much of the labor around the grounds, "in order to revive their former natural association of ideas." ${ }^{125}$ It is not surprising that the Shakers contributed money to such an institution-they often donated funds and goods to charitable organizations, the urban poor, and the victims of fires and other disasters. As early as 1801, Richard Spier, a brother at New Lebanon's Church Family, set out for Albany specifically to "inquire into the needs of the poor people at New York that are objects of charity." 126 In addition, the goals of the asylum and the activities that took place there would have appealed to the Shakers, because they reflected many of their own objectives and activities. It seems that the editors of New-Hampshire Magazine saw similarities in what they perhaps perceived to be a pastoral retreat from the world to bring about reform; the previous issue published an engraving of the Shaker village in Canterbury (Figure 33). ${ }^{127}$

Based on Swank's research, we know that the Shakers adopted some known systems of reform, particularly regarding education. After Seth Wells, a teacher in the Albany area, joined the sect in the early 1800 s, he began working to establish schools in Watervliet and New Lebanon with the permission of the central ministry. $\mathrm{He}$ introduced the Lancasterian system developed by the English Quaker reformer Joseph Lancaster to New Lebanon. This system appeared to be a good fit for the Shakers, given its nonsectarian emphasis, its ban on corporal punishment, and its stress on reading, writing, and arithmetic to provide a practical education. ${ }^{128}$ In 1862-63, the Canterbury Shakers built a new schoolhouse incorporating the ideas of education reformers, including William Alcott, Henry Barnard, and Horace Mann, 


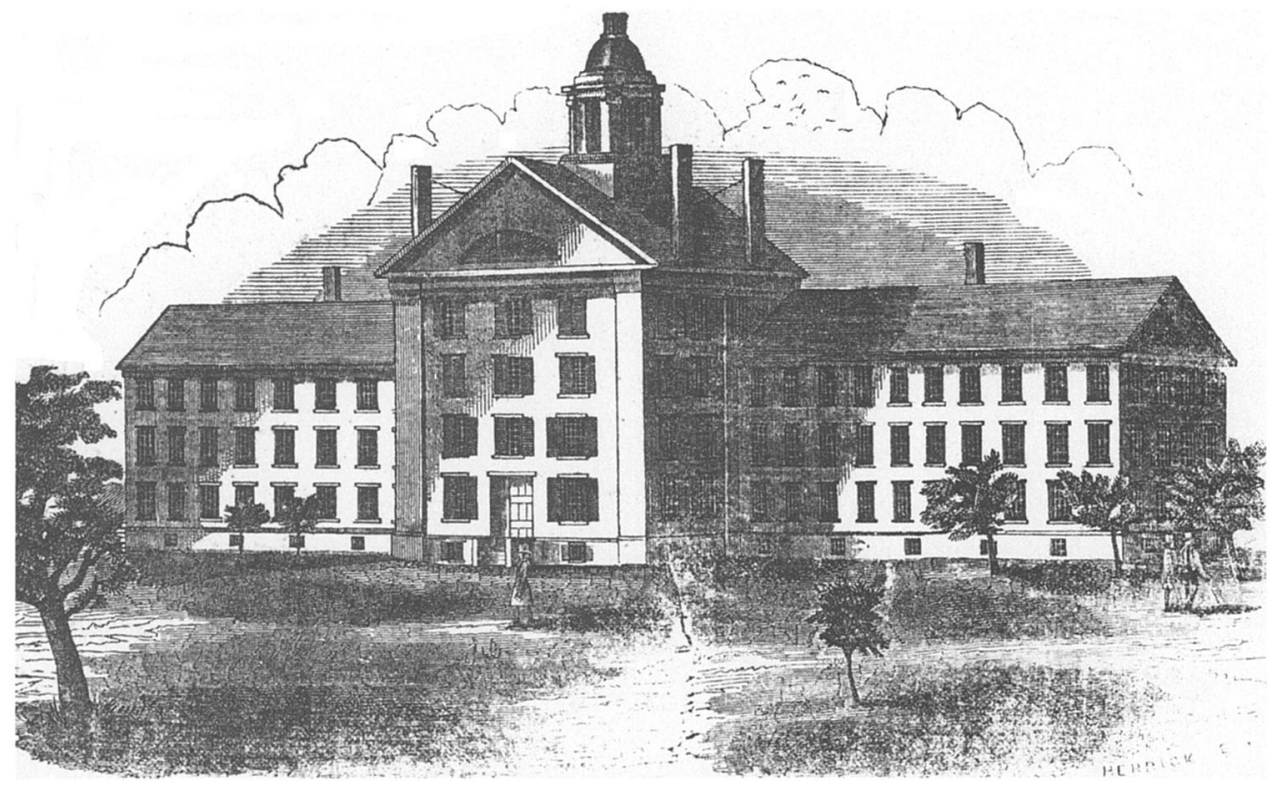

Figure 32 "New-Hampshire

Asylum for the Insane,"

Concord, New Hampshire.

From New-Hampshire

Magazine 1 (Nov. 1843), 73

who believed that architecture had a "direct influence in shaping a child's behavior and character." 29

The desire for total control of their respective environments among reformers of prisons and insane asylums and the Shakers is evident in the similar forms of architecture they chose to achieve their ends. The Massachusetts State Penitentiary, the New Hampshire Asylum for the Insane, the New Lebanon Church Family's Great House, and the Great Stone Dwelling at Enfield, to name only a few examples, all present a massive but somewhat domestic appearance with their gabled roofs and symmetrical façades. However, the rows of endlessly repetitive windows and strict classification of interior space underscore the process of assimilation to a way of life that occurred, or that the supervisors hoped would occur, within the buildings' walls.

In the early years, the Shakers handled deviants in much the same manner that eighteenth-century towns did. As long as brothers and sisters conformed to the society's code of behavior, they could remain in the community. Elders either asked members who repeatedly disregarded the rules to leave or sent them back to their families. In New Lebanon, for example, the possibly insane Sally Dean, described by Isaac Youngs as "a very singular and serious case and misterious $[s i c]$ to us all," was taken to relatives in Providence, Rhode Island. ${ }^{130}$ The Shakers' numerous rules and their strictness kept all but the most dedicated individuals from joining the sect. Those who did convert but soon chafed under the restrictions of Shaker life usually ran away of their own accord. "Bramin Wicks \& Christiana Yon, having dispised $[s i c]$ the gospel \& loved the world, withdrew from our soci- ety last night, after bed time!"'131 In other situations, the apostasy of a member brought relief to the remaining brothers and sisters: "A man ... by the name of George Hazard, who has been staying at the North Family about 3 months ... leaves to day, after acting most rascally in trying to destroy some of the young females of the family." 132

Mentally ill Shakers presented an unusual problem for the society. Although they sometimes disrupted the regular workings of the village, they rarely fled on their own. Elders were reluctant to banish their imbalanced brethren, because they saw them as part of the community and did not consider them inherently evil but merely sick. The family journals of the early nineteenth century suggest that Shakers dealt with their insane by tolerating them, as most Americans did at the time. The Believers, however, sometimes requested natural relations to remove deviant members from the community if they became dangerous to themselves or to others. An apostate noted that members who had not signed the covenant, and thus had not given up their possessions to the sect, were at the mercy of the elders. According to one account, when a young man went mad, "they lost no time, but went immediately and cast him upon the town as a pauper; and thus got rid of him." ${ }^{133}$ Mid-nineteenth-century journal accounts tell of insane sisters being locked up in small rooms or closets for extended periods of time. At the New Lebanon South Family complex, brothers constructed a small cell in the basement of the infirmary to contain a young sister who was otherwise impossible to subdue (Figure 34). Although the cell reflects Shaker ingenuity, in the wooden commode and sliding door used to 


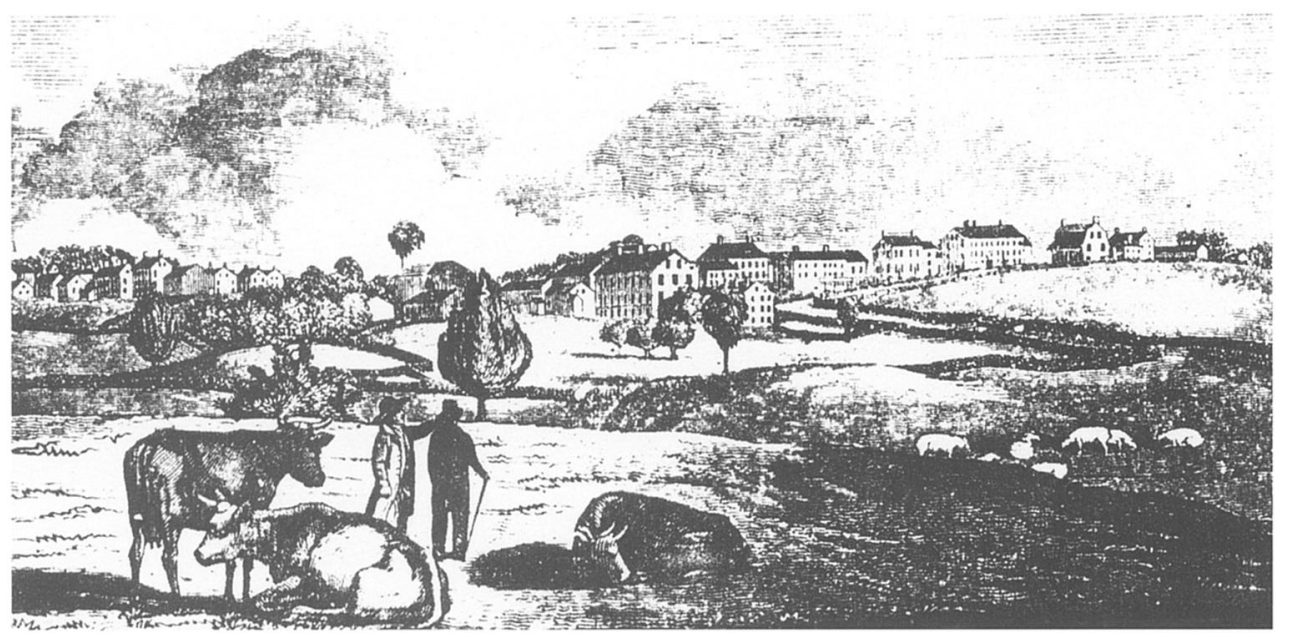

Figure 33 "Shaker Village, Canterbury, N.H." From NewHampshire Magazine 1 (Oct. 1843), 49

remove waste and to provide meals, it is a disturbing reminder of how the Shakers treated members who could not be controlled with verbal sanctions alone.

It was not until the late 1800 s that the Shakers were willing to put one of their own in an asylum. Sister Sarah Ann Spencer of the New Lebanon Church Family had been a member for many years before she went insane. After tolerating her condition for more than a year, the elders confined her to the southeast room of the wash house, and a year later, moved her to the north lower room. ${ }^{134}$ In December 1888, after calling in two doctors to examine Sister Sarah Ann, the family decided to commit her to an asylum in Poughkeepsie, New York: "After much debate and studying the pro's and con's it has been decided to place Str. Sarah A Spencer in an institution where she will be taken care of and treated in such manner as her case demands; hoping thereby, that she may be more comfortably and pleasantly situated than it was in our power to make her under the circumstances." ${ }^{135}$ The tone of the journal excerpt reveals that by this time the Shakers, like the rest of society, considered asylums to be a comfortable and convenient place to leave the mentally ill without expecting them to be cured. Sarah Ann Spencer remained in Poughkeepsie until her death in August 1897; she was buried in New Lebanon, indicating that the Shakers still considered her a member of the community.

Why did the Shakers' treatment of their mentally ill residents change over time? In the first half of the century, the society was still very concerned with the way the outside world perceived them. Although the Shakers had, for the most part, abandoned the ecstatic worship of the late 1700s, many people continued to regard them as a radical religious sect that, under Mother Ann, had brainwashed people to join their ranks. The changing treatment of the insane in Shaker communities also reflects the shifts occurring in mainstream society. Over time, more Americans accepted the role of asylums as the proper places to treat insane family members.

Although there is little evidence of direct links between the Shakers and contemporary reformers, there are enough similarities to suggest that the Shakers were aware of developments in nineteenth-century institutional architecture. It is more difficult, however, to determine who influenced whom. We have already seen the extent to which the Shakers held an interest in the affairs of the world. The numerous visitors and articles on the Shakers in newspapers and journals display the interest the sect provided for social reformers and critics of communal societies. More important was the way outsiders perceived the Shakers in the context of American reform movements. On their tours of the United States, Beaumont, Tocqueville, and Dickens traveled with the purpose of examining the various social and institutional experiments forming in the new republic. ${ }^{136}$ These men visited prisons, factories, hospitals, and insane asylums. They also made special trips to visit the Shaker villages in New Lebanon and Watervliet because they considered them to be experiments in social reform.

By the 1860s, however, society's optimism in the ability to reform had diminished. According to "A Report of the Select Committee Appointed to Visit Charitable Institutions" in the state of New York (1857), jails and penitentiaries were in poor condition. ${ }^{137}$ As legislatures passed more laws requiring prison sentences as a form of punishment, a growing stream of convicts filled penitentiaries to the bursting point. However, neither state authorities nor reformers provided ways to house these new inmates properly or to reform them. By 1866, more than one prisoner occupied each cell at the Eastern State Penitentiary, once famous for its enforcement of solitary confinement. ${ }^{138}$ 


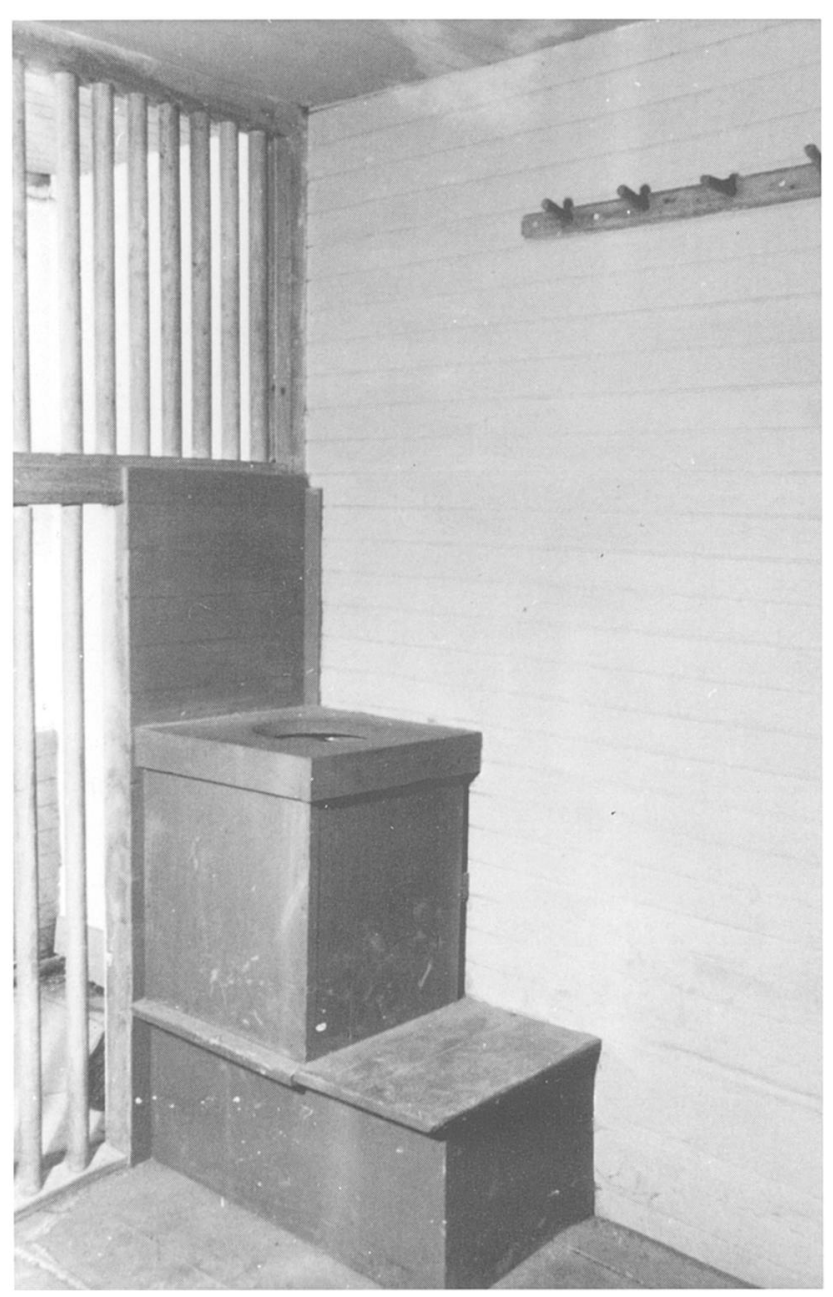

Figure 34 Cell, infirmary, South Family, New Lebanon. Undated photograph

Similar problems occurred in insane asylums. As Americans became accustomed to sending mentally ill family members to institutions rather than caring for them at home, hospitals and asylums became inundated with patients. Laws requiring state-run facilities to accept the poor insane even if there was no room resulted in declining quality of treatment. Asylum directors found themselves burdened with an increasing number of chronic, incurable cases. ${ }^{139}$ The function of both prisons and asylums became incarceration rather than care and reform.

As prison and asylum officials saw their system of reform fall apart because of overcrowding, Shaker elders saw their own system collapse because of declining membership. After a peak in 1840 of 3,608 Shakers nationwide, membership dropped every decade. By 1900, there were only 855 members left in the United States. ${ }^{140}$ The shrink- ing number of Shakers living in the dwelling houses made rules difficult to enforce because members could not be as easily supervised. The evangelical fervor of the Second Great Awakening that had attracted so many converts had long given way to complacency and worldliness. The order that the Shakers had imposed on their communities to control members and gain respectability in the larger world also resulted in dampening the enthusiasm that had made the religion so appealing in the first place.

Another problem the sect faced was the failure to recruit and retain young Shakers, thus undermining the community's economic base as the median age of members rose. ${ }^{141}$ In the late 1800s and early 1900s, many states passed laws that prevented the Shakers from legally adopting children, who had been an important source of new Shakers. Such changes gradually eroded the elders' faith in their ability to manage and control the community. They reacted by relaxing the rules in an attempt to keep young Shakers; however, this policy only served to destroy the fundamental Shaker identity of separateness and hope for salvation. By the late nineteenth century, they realized the futility of these initiatives, so the elders resigned themselves to dying out.

Nevertheless, the communal nature of Shaker architecture has allowed some villages to continue to serve institutional functions as schools, prisons, and retirement communities. In 1929, the Darrow School purchased many of the Church, Center, and North Family buildings in New Lebanon. The three remaining dwelling houses have been used as dormitories. Since 1975, the South Family buildings have housed the Sufi, members of an Islamic sect who live and work communally in the dwelling house and shops, not unlike the buildings' original occupants. Though many Church Family buildings in Watervliet have been torn down, some of them remain as the Ann Lee Health-Related Facility, owned by Albany County. The Enfield, Connecticut, Shirley, Massachusetts, and Groveland, New York, communities are now the sites of state correctional institutions. Union Village, once the largest Shaker settlement in the West, is known today as Otterbein Lebanon, a privately run retirement community. Only traces of the Shakers' huge building program remain: the Trustees' House, known as Marble Hall, and the Center Family brick dwelling. ${ }^{142}$

The failure of these experiments in using architecture to reform is instructive. Within thirty years, some of the most optimistic and energetic groups such as the Shakers and the Quakers had given up the idea of improving society through the creation of ordered environments, whereas movements such as abolitionism and women's suffrage continued and eventually succeeded in achieving their goals. 
The confidence in using architecture as a tool of reform on a widespread social and institutional level has not been the same since the early 1800 s, but it continues in projects such as urban renewal, suburban development, and neotraditionalism.

Although few direct connections exist between the Shakers' desire for reform and that of the larger society, looking back at their common roots may reveal more links. The religious tradition of dissent, the intellectualism of the Enlightenment, and the evangelical impulse of the Second Great Awakening shared by the Shakers and many of their fellow Americans gave birth to the desire for reform and the search for order. These needs encouraged classification of deviant individuals into larger groups and supervision to ensure consistent behavior among the groups. In the cases of convicts, the insane, and communal societies such as the Shakers, large structures provided the only feasible way to house people. The search for order resulted in an architecture of control based on traditional forms and technological and social innovations.

\section{Notes}

I would like to thank Zeynep Çelik and an anonymous reader for providing comments that helped me focus the argument of this article and produce a stronger analysis of Shaker architecture. I also extend my thanks to Nancy Stieber and Diana Murphy for their editorial assistance.

1. I focus in particular on the village originally called New Lebanon. In 1861 , a post office was established in the village, so the Shakers changed the name to Mount Lebanon to distinguish their community from the nearby town of New Lebanon. In this article, I refer to the Shaker settlement as New Lebanon.

2. I first presented this argument in my dissertation, "Structures for Communal Life: Shaker Dwelling Houses at Mount Lebanon, New York" (Ph.D. diss., Yale University, 1993).

3. Robert P. Emlen, Sbaker Village Views (Hanover, N.H., 1987), 3-4. 4. June Sprigg and Paul Rocheleau, Shaker Built: The Form and Function of Shaker Architecture (New York, 1994).

5. Julie Nicoletta, The Arcbitecture of the Shakers (Woodstock, Vt., 1995).

6. John T. Kirk, The Shaker World: Art, Life, Belief (New York, 1997), 7.

7. Scott T. Swank, Shaker Life, Art, and Arcbitecture: Hands to Work, Hearts to God (New York, 1999), 17.

8. David J. Rothman, The Discovery of the Asylum: Social Order and Disorder in the New Republic, rev. ed. (Boston, 1990), xiii.

9. David J. Rothman, "Perfecting the Prison: United States, 1789-1865," in Norval Morris and David J. Rothman, eds., The Oxford History of the Prison: The Practice of Punishment in Western Society (New York, 1995), 116.

10. Dell Upton, "Lancasterian Schools, Republican Citizenship, and the Spatial Imagination in Early Nineteenth-Century America," 7SAH 55 (Sept. 1996), 238-53.

11. Sydney E. Ahlstrom, A Religious History of the American People (New Haven, 1972), 423-27.

12. Stephen J. Stein, The Sbaker Experience in America: A History of the United
Society of Believers (New Haven, 1992), 7.

13. Clarke Garrett, Spirit Possession and Popular Religion: From the Camisards to the Sbakers (Baltimore, 1987), 217.

14. See Edward Deming Andrews, The People Called Shakers (New York, 1953; repr., New York, 1963), 54; and Garrett, Spirit Possession, 222.

15. Isaac N. Youngs, "Names and Ages of Those Who Have Been Gathered into the Church. ..," New Lebanon, N.Y., 1856, MS. 326, Shaker Manuscript Collection, Hancock Shaker Village, Pittsfield, Mass., 87. These farmers-David Darrow, Hezekiah Hammond, Jonathan Walker, and others-brought their entire families with them, and their surnames show up repeatedly in Shaker journals of the late 1700s and 1800s. See Isaac N. Youngs, "A Concise View of the Church of God and of Christ on Earth. Having Its Foundation in the Faith of Christ's First and Second Appearing New Lebanon1856," New Lebanon, N.Y., MS. 861, Edward Deming Andrews Memorial Shaker Collection, Winterthur Museum and Library, Winterthur, Del., 55.

16. For a discussion of how Meacham's changes affected early Shaker architecture, $\rightarrow$ Julie Nicoletta, "The Gendering of Order and Disorder: Mother Ann Lee and Shaker Architecture," New England Quarterly 74 (June 2001), 303-16.

17. Seth Y. Wells, "Records Kept by Order of the Church," New Lebanon, N.Y., 1780-1840, MS. 7, Shaker Manuscript Collection, Rare Books and Manuscript Division, New York Public Library (NYPL), N.Y., n.d., unpag. 18. Meacham's use of the word "bishopric" points to more traditional Protestant terminology. Perhaps he used the term to validate his methods of organization by connecting the new hierarchical order with one from the past. Unfortunately, there is no evidence to substantiate this claim.

19. The full title of the laws is: "The Millennial Laws or Gospel Statutes and Ordinances adapted to the Day of Christ's Second Appearing. Given and established in the Church for the protection thereof by Father Joseph Meacham and Mother Lucy Wright The presiding Ministry and by their Successors The Ministry and Elders. Recorded at New Lebanon Augst 7th 1821. Revised and re-established by the Ministry and Elders Octr 1845." Reprinted in Andrews, People Called Shakers, 285-86.

20. Stein, Shaker Experience, 73-76. Stein examines the tensions that arose between the western Shakers and the central ministry; a number of western Shakers produced theological writings in the early 1800 s, threatening the authority of the leaders in New Lebanon.

21. See Nicoletta, Arcbitecture of the Shakers, 25 (see n. 5); Kirk, Shaker World, 44-45 (see n. 6); and Swank, Shaker Life, 23 (see n. 7).

22. Andrew Skotnicki, Religion and the Development of the American Penal System (Lanham, Md., 2000), 30.

$\rightarrow$ Bruce Dorsey, "Friends Becoming Enemies: Philadelphia Benevolence and the Neglected Era of American Quaker History," Fournal of the Early Republic 18 (fall 1998), 403.

24. Edwin Scott Gaustad, A Religious History of America, rev. ed. (New York, 1990), 128-29.

25. Dorsey, "Friends Becoming Enemies," 399.

26. Elkanah Watson, Memoirs of Elkanah Watson (New York, 1857), unpag. 27. Benjamin Silliman, Remarks Made on a Short Tour between Hartford and Quebec in the Autumn of 1819 (New Haven, 1820), 42.

28. Dolores Hayden, Seven American Utopias: The Architecture of Communitarian Socialism, 1790-1975 (Cambridge, Mass., 1976), 77.

29. Ibid., 35.

30. "Millennial Laws," in Andrews, People Called Shakers, 277 (see n. 14).

31. Emlen, Shaker Village Views, 6-7 (see n. 3).

32. Swank, Shaker Life, 27, 37 (see n. 7).

33. Emlen, Shaker Village Views, 8.

34. An example of such a planned community is the one created from 1843 
to 1856 by the Fourierists in Colt's Neck, New Jersey.

35. Emlen's Shaker Village Views provides an excellent overview, with numerous reproductions, of the maps and plans the Shakers drew to record their villages.

36. Hayden, Seven American Utopias, 66, 68.

37. Andrews, People Called Shakers, 183.

38. "Millennial Laws," in ibid., 270.

39. Ibid., 266-67.

40. Kirk, Shaker World, 81 (see n. 6).

41. Rosabeth Moss Kanter, Commitment and Community: Communes and Utopias in Sociological Perspective (Cambridge, Mass., 1972), 52.

42. Ibid., 153.

43. Youngs, "A Concise View," 339 (see n. 15).

44. Ibid., 336-37.

45. Swank, Shaker Life, 96 (see n. 7).

46. Arthur Baker, Shakers and Shakerism (London, 1896), 15, cited in Andrews, People Called Shakers, 107

47. "Millennial Laws," in Andrews, People Called Shakers, 269.

48. Such economies of scale were common in many utopian societies, including the Fourierists' Phalanstery and the Oneida Perfectionists' Mansion House, which housed members in one large structure.

49. Robert P. Emlen, "The Great Stone Dwelling of the Enfield, New Hampshire Shakers," Old-Time New England 69 (Jan.-June 1979), 71.

50. Swank, Shaker Life, 96.

51. Nicoletta, Architecture of the Shakers, 39 (see n. 5).

52. Kirk, Shaker World, 74 (see n. 6).

53. Swank, Shaker Life, 49.

54. Such an arrangement can still be seen in the 1830 brick dwelling at Hancock Shaker Village.

55. Henri Desroche, The American Shakers: From Neo-Christianity to Presocialism (Amherst, Mass., 1971), 247. Precepts, including barring the world and worldly things, celibacy, specialized architecture to achieve these ends, agricultural and manufacturing practices, vows and confessions, ecclesiastical hierarchy, dress codes, and regular daily schedules of work and worship, are common between Shakerism and monasticism. However, other communal and religious groups share these codes of behavior and belief as well, making a direct comparison of Shakerism and monasticism problematic.

56. "A short account of the rise of Believers and a few of the most interesting occurrences that have taken place since that time," New Lebanon, N.Y., 1780-1841, MS. V:B-60, Shaker Manuscript Collection, Library of the Western Reserve Historical Society (WRHS), Cleveland, Oh., 5 Sept. 1832. 57. Isaac N. Youngs, "Domestic journal of daily occurrences," New Lebanon, N.Y., 1847-55, MS. V:B-70, WRHS, 14 Jan. 1854.

58. Elisha Blakeman, "A Journal of Occurences etc. 1834," New Lebanon, N.Y., 1834-40, MS. V:B-131, WRHS, 13 Feb. 1837.

59. Youngs, "Domestic journal of daily occurences," 24 Apr. 1850.

60. "Millennial Laws," in Andrews, People Called Shakers, 252 (see n. 14).

61. Andrew Jackson Downing, Cottage Residences; or A Series of Designs for Rural Cottages and Cottage-Villas; and Their Gardens and Grounds (New York, 1842), 14 .

62. Ibid., 15.

63. Swank, Sbaker Life, 132-33.

64. Gaston Bachelard, The Poetics of Space, trans. Maria Jolas (New York, 1964).

65. Ibid., 77.

66. Andrews, People Called Shakers, 160-61.

67. Rufus Bishop, "A Daily Journal of passing events; begun May the 19th 1839, at Watervliet. ..," New Lebanon and Watervliet, N.Y., 1839-50, MS.
2, NYPL, 7 Dec. 1841.

68. Catharine E. Beecher, A Treatise on Domestic Economy, for the Use of Young Ladies at Home, and at School (Boston, 1841), 273.

69. Sally Bushnell, “A Journal Commenced January 1st, 1848. vol. 1," New Lebanon, N.Y., 1848-50, MS. 10347, Shaker Collection, Emma B. King Library, Shaker Museum, Old Chatham (OC), N.Y., 18 Jan. 1855.

70. Michel Foucault, Discipline and Punish: The Birth of the Prison, trans. Alan Sheridan (New York, 1979); and Michel Foucault, Madness and Civilization: A History of Insanity in the Age of Reason, trans. Richard Howard (New York, 1965).

71. Rothman, Discovery of the Asylum (see n. 8).

72. For books on prisons, see Robin Evans, The Fabrication of Virtue: English Prison Architecture, 1750-1840 (Cambridge, England, 1982); Michael Ignatieff, A fust Measure of Pain: The Penitentiary in the Industrial Revolution, 1750-1850 (New York, 1978); Norman Johnston, Forms of Constraint: A History of Prison Arcbitecture (Urbana and Chicago, 2000); W. David Lewis, From Newgate to Dannemora: The Rise of the Penitentiary in New York, 1796-1848 (Ithaca, 1965); and Skotnicki, Religion and the American Penal System (see n. 22). For books on asylums and hospitals, see Leland V. Bell, Treating the Mentally Ill: From Colonial Times to the Present (New York, 1980); Charles L. Cherry, A Quiet Haven: Quakers, Moral Treatment, and Asylum Reform (London, 1989); Gerald N. Grob, The Mad among Us: A History of the Care of America's Mentally Ill (New York, 1994); and Christine Stevenson, Medicine and Magnificence: British Hospital and Asylum Architecture, 1660-1815 (New Haven, 2000); and Nancy Tomes, A Generous Confidence: Thomas Story Kirkbride and the Art of Asylum-Keeping, 1840-1883 (Cambridge, England, 1984).

73. Rothman, Discovery of the Asylum, 3; Grob, Mad among Us, 5-6.

74. Rothman, Discovery of the Asylum, 48.

75. Grob, Mad among Us, 7.

76. Rothman, Discovery of the Asylum, 53.

77. Ibid., xl-xli.

78. Cesare Beccaria, On Crimes and Punishments, trans. Mons. de Voltaire (London, 1767); and John Howard, The State of the Prisons in England and Wales (Warrington, England, 1777).

79. Norman Johnston, with Kenneth Finkel and Jeffrey A. Cohen, Eastern State Penitentiary: Crucible of Good Intentions (Philadelphia, 1994), 32.

80. Elaine Jackson-Retondo, "Manufacturing a Moral Reform: Images and Realities of a Nineteenth-Century American Prison," in Sally McMurry and Annmarie Adams, eds., People, Power, Places: Perspectives in Vernacular Architecture VIII (Knoxville, 2000), 120.

81. Jonas Hanway, Solitude in Imprisonment (London, 1776), 13; and Lewis, Newgate to Dannemora, 25.

82. Johnston, Forms of Constraint, 75; and Blake McKelvey, American Prisons: A History of Good Intentions (Montclair, N.J., 1977), 10-11.

83. Johnston, Forms of Constraint, 82.

84. Jeremy Bentham, Panopticon; or, the Inspection-House: Containing the Idea of a New Principle of Construction applicable to any sort of Establishment, in which Persons of any Description are to be kept under Inspection: and in Particular to Penitentiary-Houses, Prisons, Manufactories, Houses of Industry, Mad-Houses, Work-Houses, Lazarettos, Poor-Houses, Hospitals, and Schools: with a Plan of Management, 2 vols. (London, 1791).

85. Evans, Fabrication of Virtue, 198, 214 (see n. 72).

86. Bentham, Panopticon, 1:3.

87. Ibid., 1: 228.

88. Ibid., 2: 62-63.

89. Evans, Fabrication of Virtue, 218.

90. Bentham, Panopticon, 1: 103-23.

91. Rothman, Discovery of the Asylum, xxv-xxvi (see n. 8). 
92. Johnston, Forms of Constraint, 67.

93. Ibid., 67-68.

94. Gustave August de Beaumont and Alexis de Tocqueville, On the Penitentiary System in the United States, and Its Application in France; with an Appendix on Penal Colonies, and also, Statistical Notes (Philadelphia, 1833), 1. 95. Jackson-Retondo, "Manufacturing Moral Reform," 122 (see n. 80). 96. Philadelphia in 1824, or A Brief Account of the Various Institutions and Public Objects in this Metropolis . . (Philadelphia, 1824), 147.

97. Such advocates included Roberts Vaux and Francis Lieber, the German-American educator and prison reformer, who believed that solitary confinement was more healthful, induced more work, and prevented corruption more often than the congregate system. Francis Lieber, "Appendix," in Beaumont and Tocqueville, Penitentiary System, appendix unpag. 98. Beaumont and Tocqueville, Penitentiary System, 47. This statement can be applied to the United States' penitentiary system today, as inmate populations continue to increase and conditions worsen.

99. Ibid., 74-75.

100. Ibid., 295.

101. Ibid., 74.

102. See Vaux's description in ibid., 295.

103. Although there were women convicts in some prisons, reformers ignored their plight, ensuring only that they would be separated from male inmates. Reforms for these women came later, as their populations in prisons rose during the 1800s. For histories of women convicts in America, see Estelle B. Freedman, Their Sisters' Keepers: Women Prison Reform in America, 1830-1930 (Ann Arbor, 1981); and Nicole Hahn Rafter, Partial fustice: Women in State Prisons, 1800-1935 (Boston, 1985).

104. See Emlen, Shaker Village Views, 139 (see n. 3). Swank notes that the Canterbury Shaker libraries have extensive bound runs of Scientific American and Century. See Swank, Shaker Life, 119 (see n. 7).

105. "Millennial Laws," in Andrews, People Called Shakers, 276 (see n. 14).

106. Bell, Treating the Mentally Ill, 4 (see n. 72).

107. Tomes, Generous Confidence, 22-25 (see n. 72).

108. Grob, Mad among Us, 20 (see n. 72).

109. Tomes, Generous Confidence, 21-22.

110. Ibid., 63 .

111. Bell, Treating the Mentally Ill, 15.

112. Fifth Annual Report of the Trustees of the State Lunatic Hospital at Worcester (Boston, 1838), 7-9.

113. Reports and Other Documents Relating to the State Lunatic Hospital at Worcester, Massachusetts (Boston, 1837), 11-12.

114. Cherry, Quiet Haven, 163 (see n. 72).

115. Tomes, Generous Confidence, 89.

116. See Thomas S. Kirkbride, On the Construction, Organization and General Arrangements of Hospitals for the Insane (Philadelphia, 1854).

117. Ibid., 7.

118. Ibid., 7-9.

119. Ibid., 11.

120. Fifth Annual Report on the Hospital at Worcester, 11.

121. Kirkbride, Construction, Organization, 57.

122. "Millennial Laws," in Andrews, People Called Shakers, 272 (see n. 14).

123. Kirkbride, Construction, Organization, 60.

124. "New-Hampshire Asylum for the Insane," New-Hampshire Magazine 1 (Nov. 1843), 73.

125. Ibid., 74.

126. Jethro Turner, "A Memorandum Book," New Lebanon, N.Y., 1798-1804, MS. V:B-75, WRHS, 20 Nov. 1801.

127. "Shaker Village, Canterbury, N.H.," New-Hampshire Magazine 1 (Oct. 1843), 49. This engraving was first published in the November 1835 issue of the American Magazine of Useful and Entertaining Knowledge; see Emlen, Shaker Village Views, 139 (see n. 3).

128. Swank, Shaker Life, 75-76 (see n. 7).

129. Ibid., 77.

130. Isaac N. Youngs, “A Domestic Journal of Daily Occurances ..., " New Lebanon, N.Y., 1834-46, MS. 13500, Shaker Collection, New York State Archives, New York State Library, Albany, 27 May 1841.

131. Youngs, "Domestic journal of daily occurrences," 24 Aug. 1847 (see n. 57).

132. Giles B. Avery, "A Register of Incidents and Events . . ," New Lebanon, N.Y., 1859-74, MS. 4, NYPL, Mar. 1870.

133. David R. Lamson, Two Years' Experience Among the Shakers: Being a Description of the Manners and Customs of that People, the Nature and Policy of Their Government, Their Marvellous Intercourse with the Spiritual World, the Object and Uses of Confession, Their Inquisition, in Short, a Condensed View of Shakerism as It Is (West Boylston, Mass., 1848), 23.

134. Anna Dodgson, "1883 A Domestic Journal. Kept by Order of Deaconesses ...," Mount Lebanon, N.Y., 1883-85, MS. 10459, OC, 20 Feb. 1883; 26 Jan. 1884.

135. Deaconesses' Journal, Church Family, Mount Lebanon, N.Y., 1886-92, MS. 8853, OC, 14 Dec. 1888.

136. See Beaumont and Tocqueville, Penitentiary System (see n. 94); Alexis de Tocqueville, Democracy in America, 2 vols. (New York, 1980); George Wilson Pierson, ed., Tocqueville and Beaumont in America (New York, 1938); and Charles Dickens, American Notes for General Circulation (New York, 1842).

137. "A Report of the Select Committee ... " (1857), in The State and Pub-

lic Welfare in Nineteenth-Century America: Five Investigations, 1833-1877 (New York, 1976), 19.

138. Rothman, Discovery of the Asylum, 242 (see n. 8).

139. Ibid., 271.

140. William Sims Bainbridge, "Shaker Demographics 1840-1900: An Example of the Use of U.S. Census Enumeration Schedules," Fournal for the Scientific Study of Religion 21 (Dec. 1982), 355.

141. Priscilla J. Brewer, Shaker Communities, Shaker Lives (Hanover, N.H., 1986), 212.

142. Nicoletta, Arcbitecture of the Sbakers, 156-57 (see n. 5).

\section{Illustration Credits}

Electronic versions of photographs and drawings in the Historic American Buildings Survey collection may be found at the Library of Congress's American Memory Web site, http://memory.loc.gov/ammem/hhhtml/hhhome.html. Figures 1, 23, 27-30. Library of Congress, Prints and Photographs Division Figure 2. Library of Congress, Prints and Photographs Division, Historic American Buildings Survey, HABS, NY-6261

Figures 3, 19-20. Photographs by the author

Figure 4. Library of Congress, Prints and Photographs Division, Historic American Buildings Survey, HABS, NH, 5-ENFI.V, 1A-6

Figure 5. Library of Congress, Prints and Photographs Division, Historic American Buildings Survey, HABS, NH-75, sheet 3

Figure 6. Library of Congress, Prints and Photographs Division, Historic American Buildings Survey, HABS, NH-75, sheet 4

Figure 7. Library of Congress, Prints and Photographs Division, Historic American Buildings Survey, HABS, KY, 84-SHAKT, 2-12

Figure 8. Library of Congress, Prints and Photographs Division, Historic American Buildings Survey, HABS, KY, 71-SOUN, 2-24

Figure 9. Library of Congress, Prints and Photographs Division, Historic American Buildings Survey, HABS, KY, 84-SHAKT, 2-16

Figure 10. Library of Congress, Prints and Photographs Division, Historic 
American Buildings Survey, HABS, NY, 11-NELEB.V, 3-8

Figures 11, 13, 34. Emma B. King Library, Shaker Museum, Old Chatham, N.Y.

Figure 12. Library of Congress, Prints and Photographs Division, Historic American Buildings Survey, HABS, NY-3249, sheet 6

Figure 14. Library of Congress, Prints and Photographs Division, Historic American Buildings Survey, HABS, NY-3333, sheet 2

Figure 15. Library of Congress, Prints and Photographs Division, Historic
American Buildings Survey, HABS, NY-3249, sheet 4

Figure 16. Library of Congress, Prints and Photographs Division, Historic American Buildings Survey, HABS, NY-3249, sheet 7

Figure 18. Library of Congress, Prints and Photographs Division, Historic American Buildings Survey, HABS, NY-3333, sheet 3

Figure 21. Library of Congress, Prints and Photographs Division, Historic American Buildings Survey, HABS, MASS, 2-HANC, 4-45

Figures 24, 25. Massachusetts Archives, Boston 